\title{
DOE/CE/ $16055-T)$
}

RECENVED

FEB 151996

OSTI.

Summary of Findings

\section{Cost-Effectiveness of Trees for Demand-Side Management Washington, DC.}

\author{
E. Gregory McPherson, Lead Scientist: \\ Paul Sacamano, Research Associate \\ Steve Wensman, Research Assistant \\ Marcia Henning, Research Assistant
}

USDA Forest Service

Northeastern Forest Experiment Station

5801 N. Pulaski Road

Chicago, Tllinois 60646

(312) 539-1363

December, 1992

\section{DISCLAIMER}

This report was prepared as an account of work sponsored by an agency of the United States Government. Neither the United States Government nor any agency thereof, nor any of their employees, makes any warranty, express or implied, or assumes any legal liability or responsibility for the accuracy, completeness, or usefulness of any information, apparatus, product, or process disclosed, or represents that its use would not infringe privately owned rights. Reference herein to any specific commercial product, process, or service by trade name, trademark, manufacturer, or otherwise does not necessarily constitute or imply its endorsement, recommendation, or favoring by the United States Government or any agency thereof. The views and opinions of authors expressed herein do not necessarily state or reflect those of the United States Government or any agency thereof. 


\section{Introduction}

Trees can reduce demand for air conditioning to cool buildings by shading residences and lowering summertime air temperatures. During winter, trees can reduce heating needs by lowering wind speeds and thereby reducing infiltration of cold air. On the otherhand, winter shade from improperly located trees can increase heating requirements. Projections from computer simulations indicate that 100 million mature trees in U.S. cities ( 3 trees for every other single family home) could reduce energy use for heating and cooling by 30 billion $\mathrm{kWh}$ and reduce carbon dioxide emissions by as much as 9 million tons per year.

This energy analysis is part of a larger study that quantifies costs and benefits of proposed tree plantings in 12 U.S. cities. While energy savings is an important benefit from community forests, other benefits (e.g., air quality improvement, reduced 'stormwater runoff, increased propoerty values) can have equal or greater value. Tree planting, care, and other costs (e.g., water-sewer line repair, green waste disposal, litigation/liability, program administration) from the cost-benefit study can be used to help estimate costs associated with a tree planting program for demand-side management. Data from this energy analysis should be of direct value to local utilities, urban foresters, planners, landscape designers, and nonprofit tree planting groups to:

- Evaluate cost-effectiveness of tree planting for energy conservation in terms of potential avoided costs for energy $(\mathrm{kWh})$ and capacity $(\mathrm{kW})$.

- Evaluate avoided carbon dioxide emissions from power plants based on projected building energy savings from trees.

- Evaluate energy-efficient landscape design incentives that could be offered for new construction and retrofits of existing residential and small commercial buildings.

- Develop initial tree selection and location guidelines for design of energy-efficient landscapes.

\section{Computer Simulation Approach}

Annual cooling $(\mathrm{kWh}, \mathrm{kW})$ and heating (MBtu) energy savings from two base case residences were projected for the following scenarios:

-. Unshaded base case

- 1 tree opposite west wall

- 2 trees opposite west wall.

- 2 trees opposite west wall and 1 tree opposite east wall 
The 1,500 sq ft one story and 1,761 sq ft two story base case buildings were typical of 1960 and 1992 single family detached home design and construction. Assumptions used to model building, occupant, and HVAC characteristics are listed in Table 1. Shading from a 15 gallon ( $6 \mathrm{ft}$ tall at planting) deciduous tree was simulated for years $5(13 \mathrm{ft}), 10(19 \mathrm{ft})$, 15 (24 ft), and 20 (25 ft) after planting using the Shadow Pattern Simulator (SPS). SPS output was used by MICROPAS 4.0 to alter solar radiation on building surfaces for energy analysis. MICROPAS 4.0 used local weather data to perform hour-by-hour heatflow and zone load energy calculations. Locations and sizes of trees for selected simulation scenarios are shown in Figures 1 and 2. Dollar savings were based on typical residential energy prices obtained in 1991 and not discounted. An avoided cost of $\$ 65$ per $\mathrm{kW}$ yr was assumed for capacity savings.

Evapotranspirational (ET) cooling and wind reduction effects result from the aggregate impacts of all neighborhood trees, not just those trees directly shading the building. Based on our survey of proposed tree planting during the next five years, we simulated temperature and wind speed changes expected to accompany a 5 percent increase in local tree cover. Temperatures in the MICROPAS 4.0 weather file were lowered by as much as 2 to $4^{\circ} \mathrm{F}$ during hottest weather conditions to account for ET cooling, based on US Forest Service measurements from Phoenix landscapes. Wind speed reductions of 5 to 10 percent were simulated by modifying the local shielding class from moderate (i.e., some obstructions within two house heights, thick hedge, solid fence, or one neighboring house) to heavy (i.e., obstructions around most of perimeter, buildings or trees within $30 \mathrm{ft}$ in most directions, typical suburban shielding). Recognizing that the energy savings from ET cooling and reduced wind speeds on any particular site are due to trees on the site and in the surrounding area, we conservatively attributed these savings to the aggregate effect of three $25 \mathrm{ft}$ tall trees on-site to derive total (i.e., shade from 3 trees + ET cooling + reduced wind) and average savings per tree (i.e., total savings / 3 trees) at year 20. 
Table 1

Base Case Building Characteristics

\begin{tabular}{||l|l|l||}
\hline \hline Item & $1960-$ One Story & $1992-$ Two Story \\
\hline Floor Area (sf) & 1,500 & 1,761 \\
\hline Volume (cu ft) & 12,750 & 15,588 \\
\hline Number Stories & 1 & 2 \\
\hline Front Orientation & East & East \\
\hline Window Panes & 1 (u =1.35) & 2 (u $=0.87)$ \\
\hline Window Area (sf) & 75 per wall & 88 per wall \\
& Total $=300$ & Total $=352$ \\
\hline Window Shading Coef.. & & 0.88 \\
Glass Only. & 0.77 & 0.78 \\
\hline Drapes or Blinds & 0.78 & $\mathrm{R}-13$ \\
\hline Wall Insulation & $\mathrm{R}-7$ & $\mathrm{R}-30$ \\
\hline Attic Insulation & $\mathrm{R}-19$ & $\mathrm{R}-11$ \\
\hline $\begin{array}{l}\text { Control-Ventilated Crawlspace } \\
\text { Floor } \\
\text { Stem Wall. }\end{array}$ & $\mathrm{R}-0$ & $\mathrm{R}-5$ \\
\hline Infiltration Class & $\mathrm{R}-5$ & $\mathrm{Medium}$ \\
\hline Internal Gain (Btu/day) & $\mathrm{Medium}$ & 46,415 \\
\hline Gas Furnace Eff. & 42,500 & 0.78 \\
\hline Air Conditioner (SEER) & 0.78 & 10 \\
\hline $\begin{array}{l}\text { Thermostat Settings } \\
\text { Summer Cooling } \\
\text { Winter Heating }\end{array}$ & 10 & 78 \\
\hline \hline
\end{tabular}





Figure 1. Plan view of a 1 story residence 1,500 sq. $\mathrm{ft}$. (R-7 wall, $\mathrm{R}-19$ attic, single pane windows). 


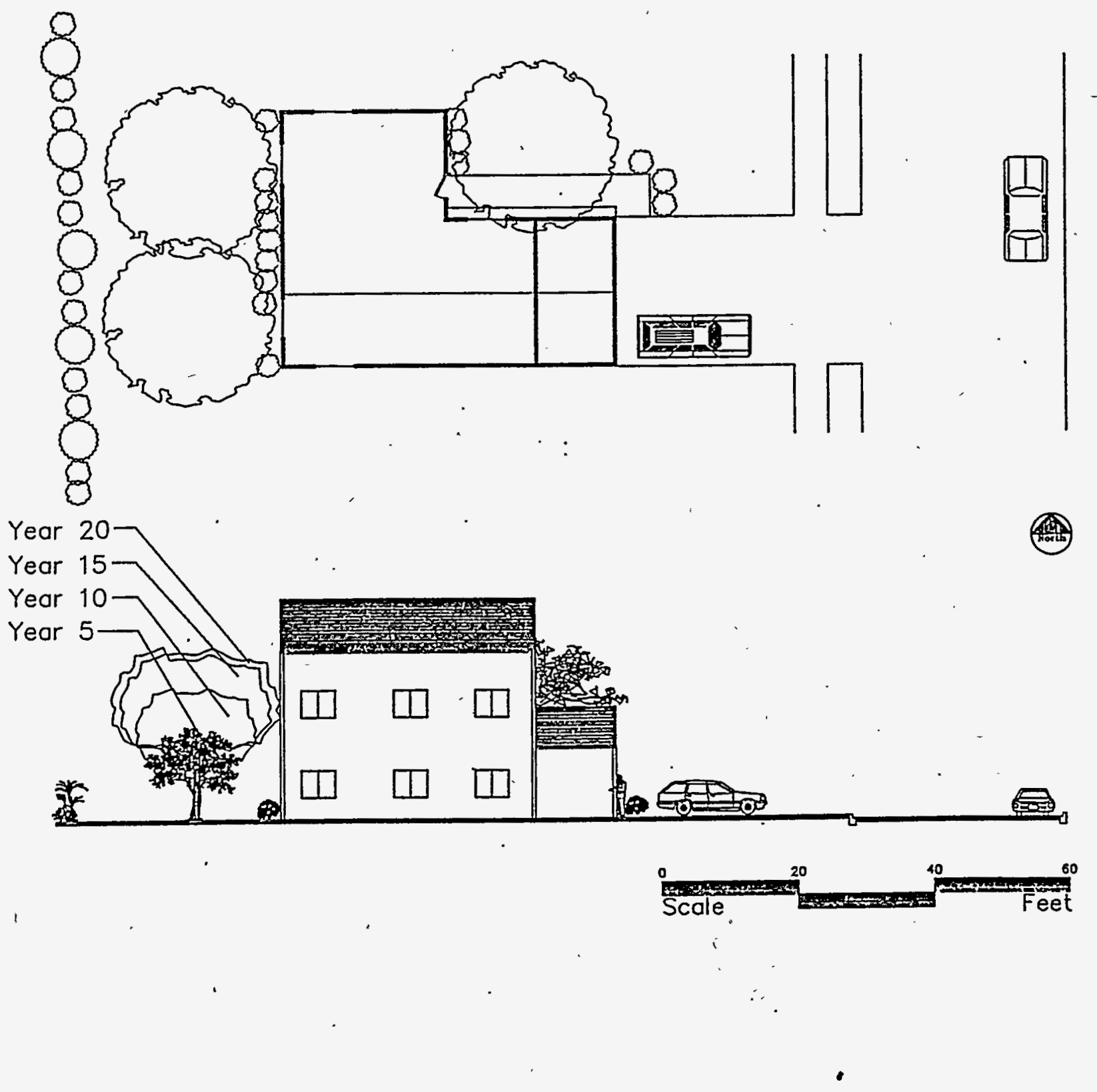

Figure 2. Plan view and section of a typical two story 1,761 sq. $\mathrm{ft}$. residence $(\mathrm{R}-19$ wall, $\mathrm{R}-$ 30 attic, double pane windows). 


\section{Findings}

Highlights from the energy analysis are summarized below and more detailed information can be found in accompanying tables and figures.

For the $25 \mathrm{ft}$ trees at year 20 we found:

- Total annual heating and cooling savings of $\$ 15(3 \%)$ per tree on average.

- Per tree average annual cooling savings of 224 and $261 \mathrm{kWh}(9-11 \%, \$ 14$ 16) and peak capacity savings of 0.25 and $0.35 \mathrm{~kW}(5-6 \%, \$ 17-23)$.

- Shading, ET cooling, and wind speed reductions make similar contributions to total savings.

For trees at different locations we found:

- Greatest cooling savings from shade on the west ( $6 \%$ per tree).

- Marginal savings from a second tree on the west was slightly less than savings from the first tree.

- Shade from the east tree increased heating costs more than it reduced cooling costs.

For trees of different ages we found:

- Increased cooling savings of 0.25 to 0.4 percent a year until trees reached near mature size at year 15.

For the different base case buildings we found:

- Although dollar savings were similar for both the 1960 and 1992 base case buildings, on a floor area basis savings from trees were greater for the less well-insulated 1960 home.

- Indirect effects of neighborhhod tree planting on air temperatures and wind speed will most benefit older homes, while shading will have a relatively greater impact on newer homes that are less influenced by heat conduction and air infiltration. 


\section{Summary and Recommendations}

- A tree located to shade typical residences in the Washington D.C. area can be expected to reduce annual cooling energy use by about $250 \mathrm{kWh}(10 \%, \$ 15)$ and peak demand by $0.33 \mathrm{~kW}(5 \%, \$ 20$ in avoided capacity) once it reaches 25 $\mathrm{ft}$ height and spread (about 15 years).

- Given these potential cooling savings, trees are likely to be cost-effective energy conservation measures for both existing homes and new residential construction.

- Other environmental benefits from trees planted for energy conservation include carbon stored by trees, avoided power plant emissions, avoided power plant water consumption, and air pollution interception and absorption.

- Maximum cooling savings and minimum heating costs will result from planting of trees to shade west-facing walls and windows. Select deciduous trees with broad canopies to shade as much of the west wall as possible.

- Trees that shade east and south walls can increase heating costs, so minimize blocking winter sunlight by selecting deciduous trees that are relatively late to leaf-out and drop leaves early (e.g., locust, ash, coffeetree).

- Cooler summertime temperatures and reduced wind speeds from neighborhood tree plantings provide heating and cooling savings comparable to those obtained from shade alone. Therefore, trees planted along streets, in parks, parking lots, and other locations may not directly shade buildings but still provide substantial energy savings for nearby residential and small commercial buildings. 
Energy analyses show effects of shading, ET cooling, and wind speed reductions from $25 \mathrm{ft}$ trees as savings from the base case buildings.

\begin{tabular}{|c|c|c|c|c|c|c|c|c|}
\hline $\begin{array}{l}\text { Washington, } \\
1 \text { Story }\end{array}$ & DC 1500 & sq ft & nergy An & Iysis & & $\begin{array}{l}\text { Nat. Gas } \\
\text { Electricity }\end{array}$ & $\begin{array}{l}\text { (\$/therm): } \\
(\$ / \mathrm{kWh}):\end{array}$ & $\begin{array}{r}0.75 \\
0.0628\end{array}$ \\
\hline Year $20-25 \mathrm{ft}$ & trees & & & & Avoided Peak & Electricity & (\$/Avoid kW): & 65 \\
\hline $\begin{array}{l}\text { Annual } \\
\text { Energy Use }\end{array}$ & $\begin{array}{l}\text { Unshaded } \\
\text { Base Case }\end{array}$ & 1 Tree & $\begin{array}{r}\text { Shade } \\
2 \text { Trees }\end{array}$ & 3 Trees & $\begin{array}{r}E T \\
\text { Cooling }\end{array}$ & $\begin{array}{r}\text { Reduced } \\
\text { Wind }\end{array}$ & $\begin{array}{c}3 \text { Tree+ET } \\
+ \text { Wind }\end{array}$ & $\begin{array}{l}\text { Avg. Savings } \\
\$ / \pi \mathrm{ree} \mathrm{Y}_{\mathrm{r}} .\end{array}$ \\
\hline Heat (MBtu) & 69.09 & 69.71 & 69.98 & 70.46 & 69.83 & 67.31 & & \\
\hline & 518.18 & 522.83 & 524.85 & 528.45 & 523.73 & 504.83 & & \\
\hline MBtu diff & & -0.62 & $\begin{array}{l}-0.89 \\
\end{array}$ & -1.37 & -0.74 & 1.78 & -0.33 & -0.11 \\
\hline & & 4466 & $-6: 67$ & -10.27 & -555 & 1335 & \% 247 & 0.02 \\
\hline$\%$ diff & & -0.90 & -1.30 & -2.00 & -1.10 & $\begin{array}{r}2.60 \\
2.60\end{array}$ & -0.50 & -0.17 \\
\hline Cool (kWh) & 2410 & 2262 & 2158 & 2111 & 1944 & 2393 & & \\
\hline & 151.35 & 142.06 & 135.51 & 132.54 & 122.10 & 150.26 & & \\
\hline $\begin{array}{l}\text { kWh diff } \\
\text { s diff }\end{array}$ & & 148 & 252 & $\begin{array}{r}300 \\
+8 \% 8 \\
\end{array}$ & $\begin{array}{r}466 \\
0 \% 5\end{array}$ & 17 & $\begin{array}{r}783 \\
015\end{array}$ & 261.00 \\
\hline$\%$ diff & & $\begin{array}{r}6.14 \\
6.14\end{array}$ & 10.47 & 12.43 & $\begin{array}{l}19.33 \\
19.3\end{array}$ & 0.72 & 32.48 & $\begin{array}{r}10.83 \\
10.00\end{array}$ \\
\hline Total (MBtu) & OP & 95.65 & 94.87 & 94.88 & 92.52 & & & \\
\hline & 669.5 & 664.89 & 660.38 & 660.99 & 645.83 & 655.09 & & \\
\hline MBtu diff & & 0.88 & 1.66 & 1.65 & 4.01 & 2.03 & 7.69 & 2.56 \\
\hline$\$$ dift & & $4: 64$ & 191 & 854 & 2370 & 1484 & 46.68 & 15.56 \\
\hline$\%$ diff & & 0.91 & 1.72 & 1.71 & 4.15 & 2.10 & 7.97 & 2.66 \\
\hline Peak & $\cdot 5.6$ & 5.19 & 4.93 & 4.93 & 5.25 & 5.58 & & \\
\hline & 364.00 & 338.00 & 321.00 & 321.00 & 341.00 & 362.00 & & \\
\hline Kw difi & & 0.41 & 0.67 & 0.67 & 0.36 & 0.03 & 1.06 & 0.35 \\
\hline & & 2600 & 4300 & 4300 & $2300 \mathrm{~s}$ & 200 & 68.00 & $\%<2267$ \\
\hline & & 7.35 & 11.98 & 11.99 & 0.37 & 0.51 & 18.87 & 6.29 \\
\hline
\end{tabular}

Annual Dollar Savings From Base Case -3 Trees ( $25 \mathrm{ft}$. tall)

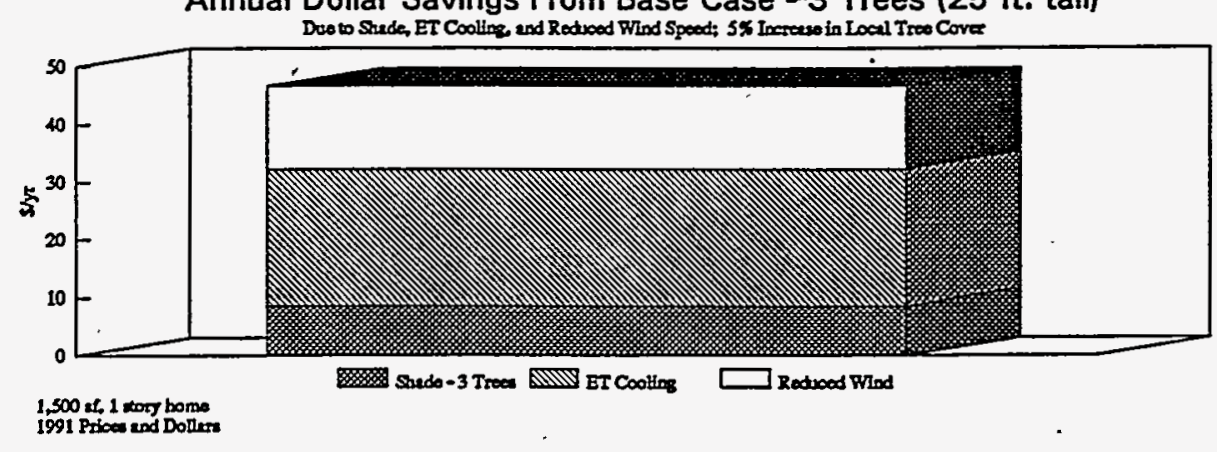

Average Annual Dollar Savings From Base Case - 1 Tree (25 ft. tall) Dvo wo Sheder ET Cooling, end Reduced What Speed: 58 Increese in Locel Troo Cover

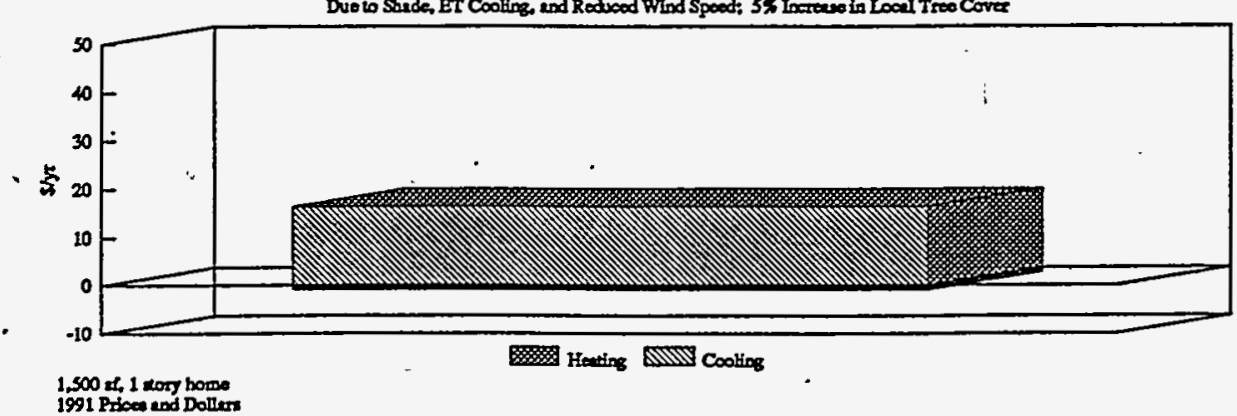




\section{Annual Dollar Savings From Base Case}

in 1991 Prices and Dollers

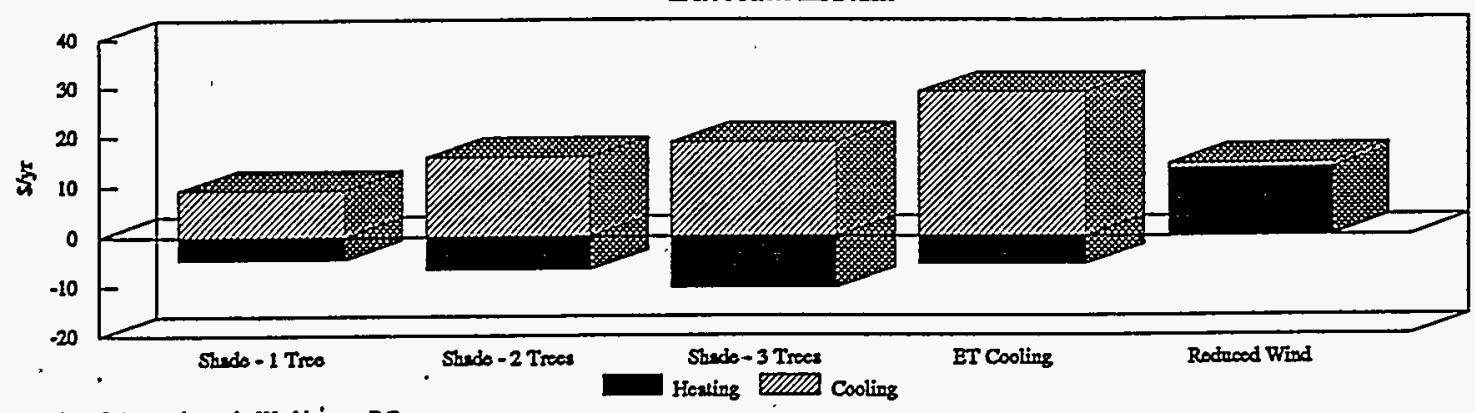

1,500 sf, 1 rety home in Weatingitor, DC
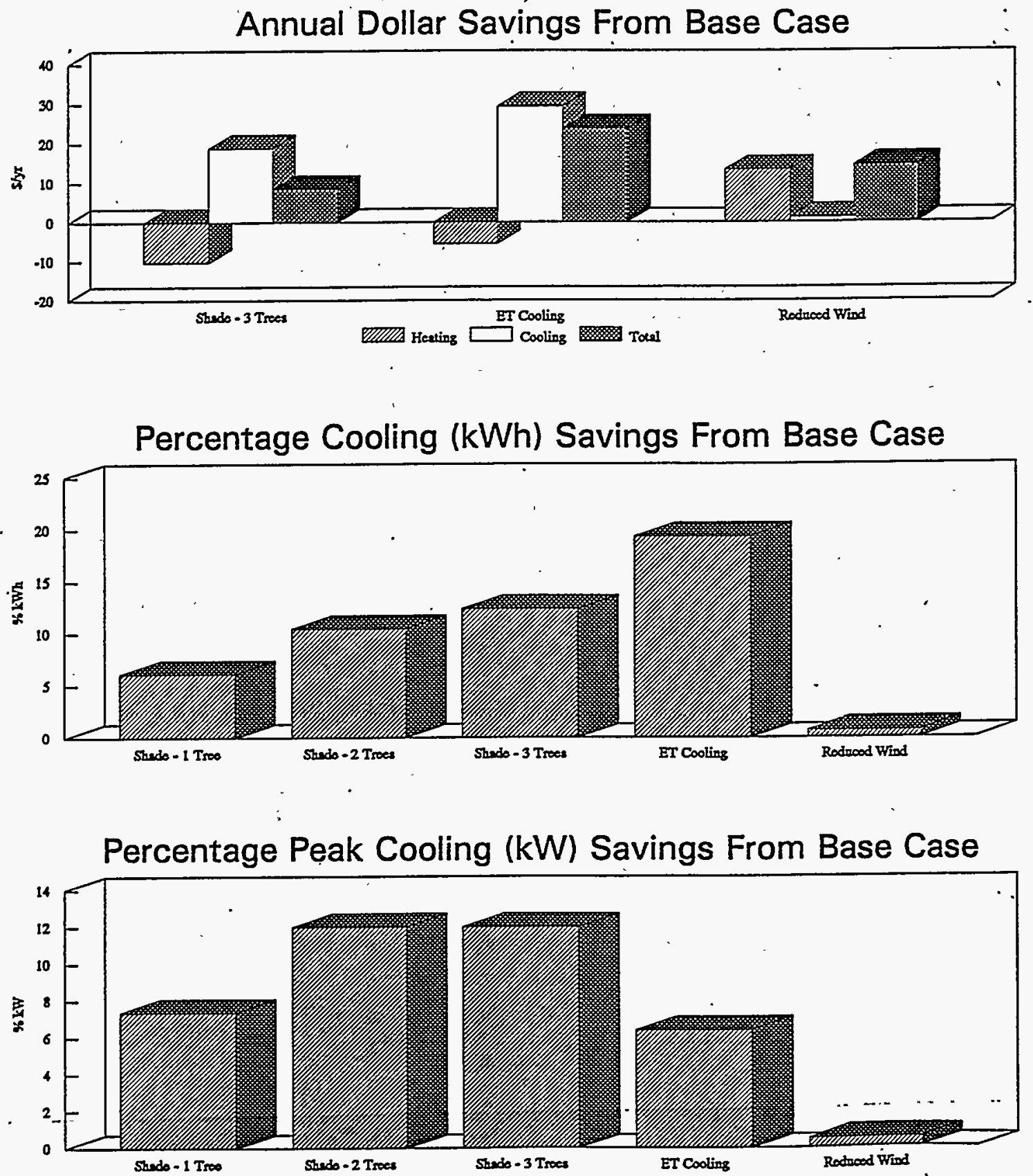


\begin{tabular}{|c|c|c|c|c|c|c|c|c|}
\hline $\begin{array}{l}\text { Washington, } \\
2 \text { Story }\end{array}$ & 1761 & $\mathrm{sq} \mathrm{ft}$ & lergy Ana & lysis & & $\begin{array}{l}\text { Nat. Gas } \\
\text { Electricity }\end{array}$ & $\begin{array}{l}\text { (\$/therm): } \\
\text { (\$/kWh): }\end{array}$ & $\begin{array}{r}0.75 \\
0.0628\end{array}$ \\
\hline Year $20-25 \mathrm{ft}$ & trees & & & & Avoided Peak & Electricity & (\$/Avoid kW): & 65 \\
\hline $\begin{array}{l}\text { Annual } \\
\text { Energy Use }\end{array}$ & $\begin{array}{l}\text { Unshaded } \\
\text { Base Case }\end{array}$ & 1 Tree & $\begin{array}{r}\text { Shade } \\
2 \text { Trees } \\
\end{array}$ & 3 Trees & $\begin{array}{r}\text { ET. } \\
\text { Cooling }\end{array}$ & $\begin{array}{r}\text { Reduced } \\
\text { Wind }\end{array}$ & $\begin{array}{r}3 \text { Tree +ET } \\
+ \text { Wind } \\
\end{array}$ & $\begin{array}{l}\text { Avg. Savings } \\
\text { \$ / Tree/Yr. }\end{array}$ \\
\hline Heat (MBtu) & $\begin{array}{r}65.33 \\
489.98\end{array}$ & $\begin{array}{r}65.67 \\
492.53\end{array}$ & $\begin{array}{r}65.85 \\
493.88\end{array}$ & $\begin{array}{r}66.24 \\
496.80\end{array}$ & $\begin{array}{r}65.99 \\
494.93\end{array}$ & $\begin{array}{r}63.22 \\
474.15\end{array}$ & & \\
\hline MBtu diff & & -0.34 & -0.52 & -0.91 & -0.66 & 2.11 & 0.54 & 0.18 \\
\hline$\$$ diff & & 12255 & -390 & -6882 & 4.49 & $\% 1583$ & 406 & 1135 \\
\hline$\%$ diff & & -0.50 & -0.80 & -1.40 & -1.00 & 3.20 & 0.80 & 0.27 \\
\hline $\begin{array}{l}\text { Cool (kWh) } \\
\$\end{array}$ & $\begin{array}{r}2376 \\
149.21\end{array}$ & $\begin{array}{r}2214 \\
139.02\end{array}$ & $\begin{array}{r}2104 \\
132.13\end{array}$ & $\begin{array}{r}2046 \\
128.51\end{array}$ & $\begin{array}{r}2057 \\
129.20\end{array}$ & $\begin{array}{r}2354 \\
147.84\end{array}$ & & \\
\hline kWh diff & & 162 & 272 & $\begin{array}{r}330 \\
\end{array}$ & 319 & 22 & 671 & 223.67 \\
\hline$\$$ diff & & 1019 & 1708 & 2070 & 20.01 & 137 & 42.08 & \% 1403: \\
\hline$\%$ diff & & 6.83 & 11.45 & 13.87 & 13.42 & 0.92 & 28.21 & 9.40 \\
\hline Total (MBtu) & 92.26 & 90.96 & 90.02 & 89.83 & 89.68 & 89.84 & & \\
\hline & 639.19 & 631.55 & 626.01 & 625.31 & 624.13 & 621.99 & & \\
\hline MBtu diff & & 1.30 & 2.24 & 2.43 & 2.58 & $\begin{array}{r}2.42 \\
\end{array}$ & 7.43 & 2.48 \\
\hline & & 764 & 1318 & 13888 & $* 1506$ & $\% 1720$ & 4614 & 1538 \\
\hline & & 1.41 & 2.43 & 2.63 & 2.80 & 2.62 & 8.05 & 2.68 \\
\hline Peak Cool (kW) & 5.04 & 4.70 & 4.53 & 4.53 & 4.83 & 5.02 & & \\
\hline Avoided \$ & 328.00 & $\begin{array}{r}305.00 \\
0.35\end{array}$ & $\begin{array}{r}294.00 \\
05 ?\end{array}$ & $\begin{array}{r}294.00 \\
0.52\end{array}$ & $\begin{array}{r}314.00 \\
0 ? 1\end{array}$ & $\begin{array}{r}326.00 \\
0.03\end{array}$ & 076 & \\
\hline $\begin{array}{l}\text { Kw diff } \\
\text { Avoided \$ diff }\end{array}$ & & $\begin{array}{r}0.36 \\
23.000\end{array}$ & 0.52 & $\begin{array}{r}0.52 \\
3400\end{array}$ & $\begin{array}{r}0.21 \\
1400\end{array}$ & 1.05 & 50.00 & \%४16.67 \\
\hline$\%$ diff & & 6.85 & 10.26 & 10.27 & 4.22 & 0.57 & 15.07 & $\begin{array}{r}5.02 \\
\end{array}$ \\
\hline
\end{tabular}

Annual Dollar Savings From Base Case - 3 Trees (25 ft. tall)

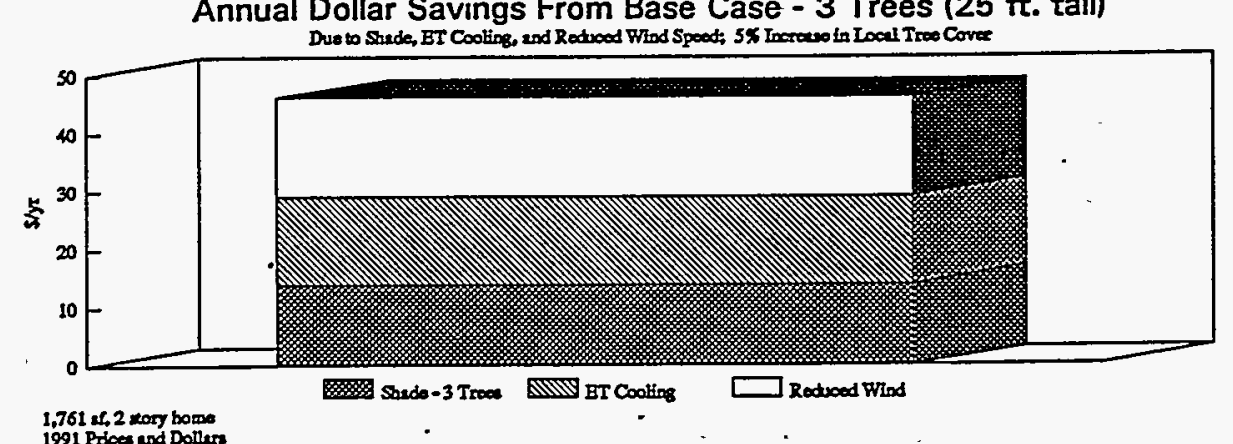

1,761 sf, 2 rory home
1991 Prices und Dollers

Average Annual Dollar Savings From Base Case - 1-Tree (25 ft. tall)

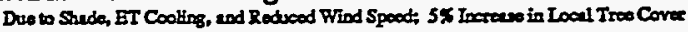

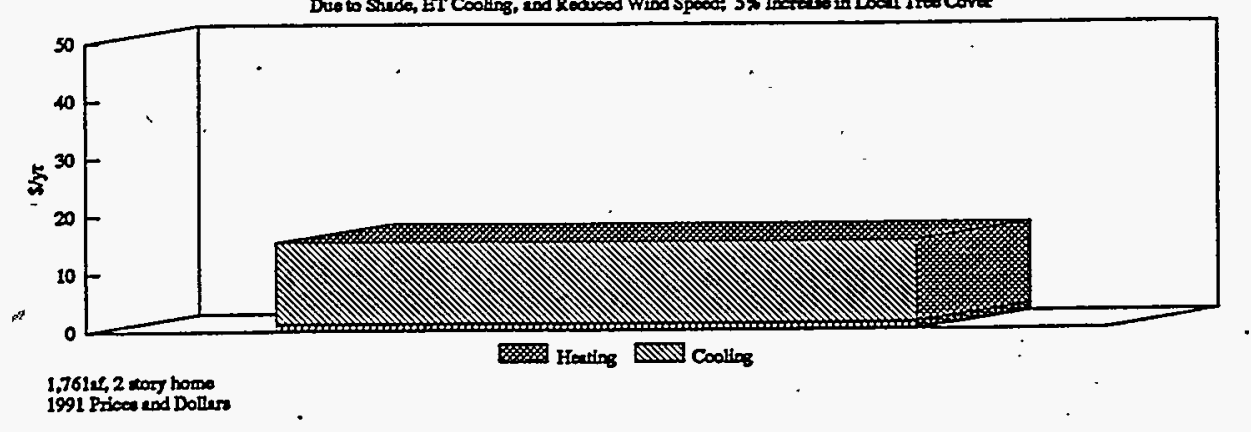




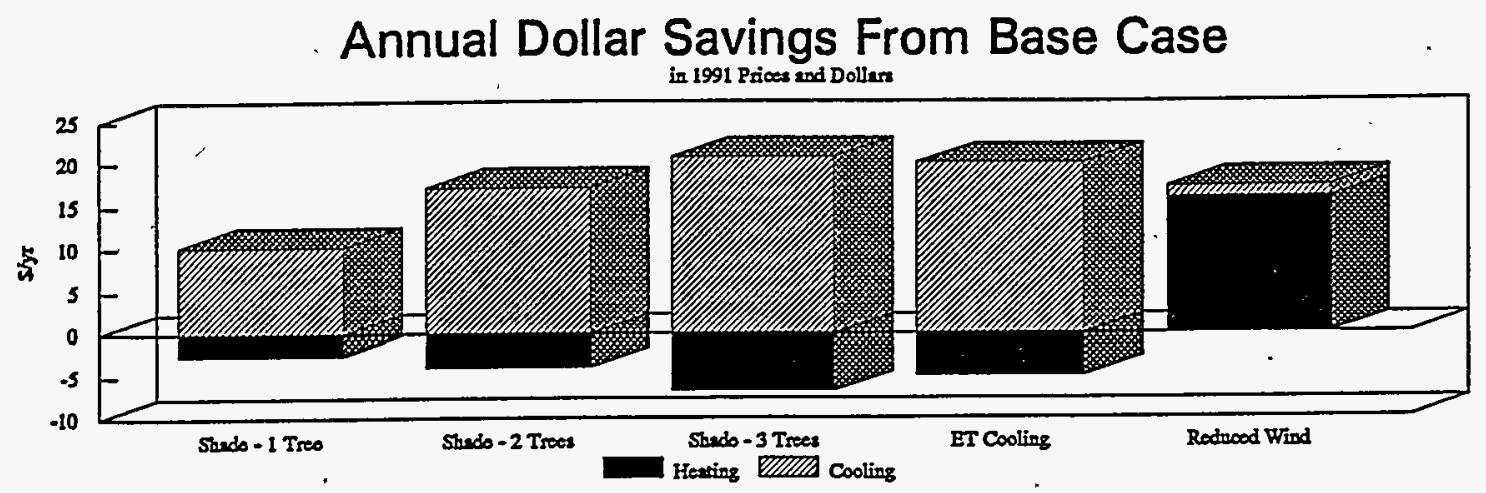

1,761 af, 2 atogy home in Wustington, DC
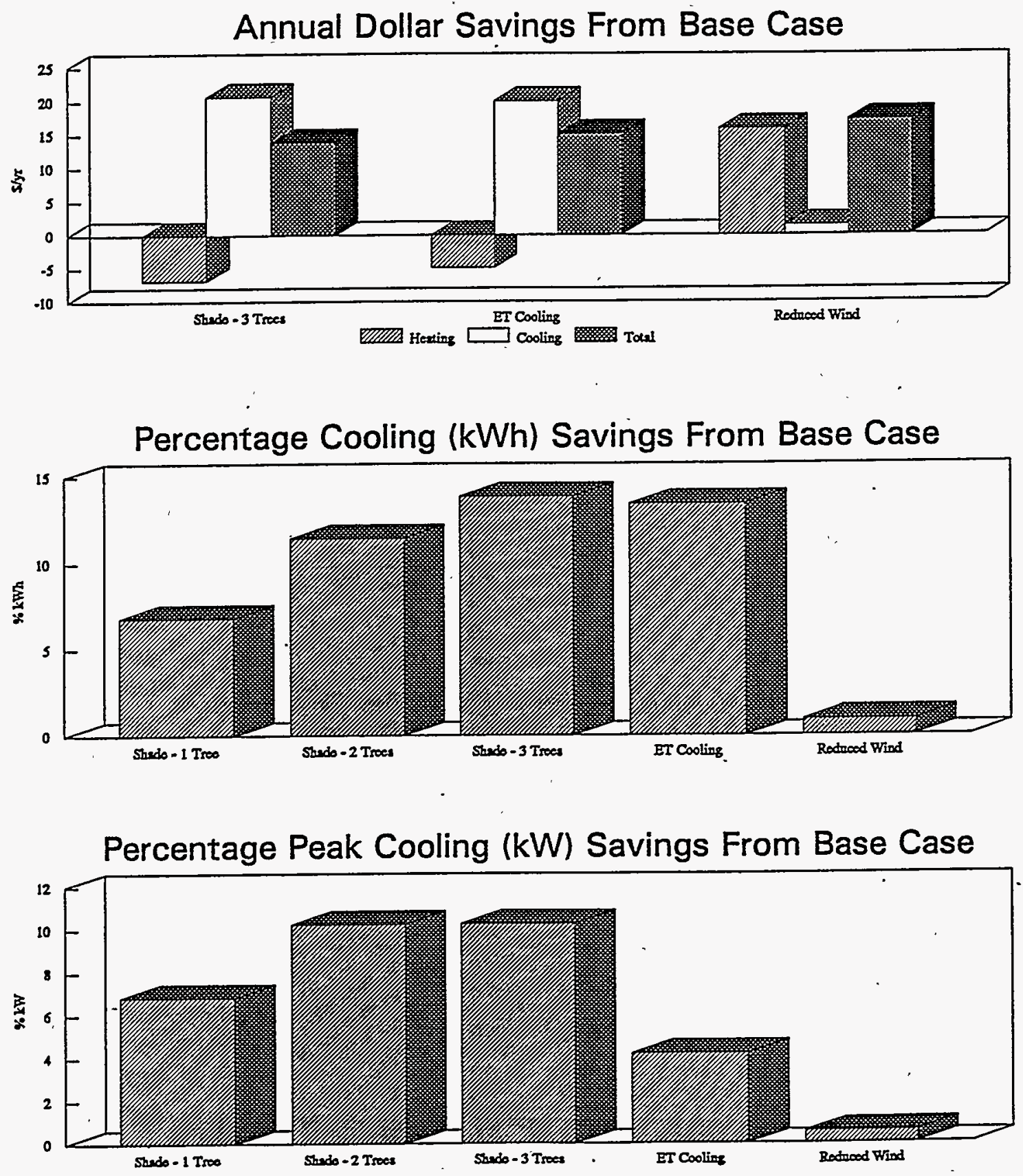
Tree shade only analysis shows projected energy impacts from 1 tree (opposite west wall), 2 trees (both opposite west wall), and 3 trees (third tree opposite east wall) at $5,10,15$, and 20 years after planting.

Washington; DC

1 Story - 1,500 sq ft Residence

Tree Shade Only

Space Conditioning Source Energy Use (kBtu/ sq ft)

Year 5

Total Heating Use

Total Cooling Use

Total Energy Use

Peak Cool (kW)

Year 10

Total Heating Use

Total Cooling Use

Total Energy Uso

Peak Cool (kW)

Year 15

Total Heating Use

Total Cooling Use

Total Energy Use

Peak Cool (kW)

Year 20

Total Heating Use

Total Cooling Use

Total Energy Use

Peak Cool (kW)

Annual Energy Use

Year 5

Heating (kBtu)

Cooling (kWh)

Year 10

Hesting (kBtu)

Cooling (kWh)

Year 15

Cooling (kWh)

Year 20

Heating (kBtu)

Cooling (kWh)

47.90

16.45

64.35

48.25

64.06

5.60

47.90

16.45

64.35

5.60

5.39

48.32

15.50

63.82

5.22

47.90

16.45

48.33

64.35

15.44

63.77

5.19

5.60
Heating (kBtu)

\begin{tabular}{rrrr} 
Base Case & 1 Tree & 2 Tree & 3 Tree \\
\hline 47.90 & 48.17 & 48.24 & 48.33 \\
16.45 & 16.16 & 15.94 & 15.91 \\
64.35 & 64.33 & 64.18 & 64.24 \\
5.60 & 5.55 & 5.53 & 5.53
\end{tabular}

15.87

48.37

15.29

63.66

5.23

48.58

15.13

63.71

48.49

14.80

63.30

4.98

48.52

14.73

83.25

4.93

\begin{tabular}{rrrr} 
Base Case & 1 Tree & 2 Tree & 3 Tree \\
\hline 69093 & 69482 & 69579 & 69713 \\
2410 & 2367 & 2335 & 2330 \\
69093 & 69595 & 69767 & 70069 \\
2410 & 2316 & 2240 & 2217 \\
69093 & 69693 & 69946 & 70394 \\
2410 & 2271 & 2169 & 2127 \\
69093 & 69712 & 69982 & 70458 \\
2410 & 2262 & 2158 & 2111 \\
\hline
\end{tabular}

Heating and Air Conditioning Hours of Use

Year 5

Heating (hrs)

Cooling (hrs)

Year 10

Heating (hrs)

Cooling (hrs)

Year 15

Heating (hrs)

Cooling (hrs)

Year 20

Heating (hrs)

Cooling (hrs)

\begin{tabular}{rrrr} 
Base Case & 1 Tree & 2 Tree & 3 Tree \\
\hline 3158 & 3175 & 3209 & 3209 \\
1078 & 1070 & 1070 & 1070
\end{tabular}

$\begin{array}{lllll}3158 & 3201 & 3209 & 3227\end{array}$

$1078 \quad 1070$

$\begin{array}{llll}3158 & 3209 \quad 3218 \quad 3244\end{array}$

$\begin{array}{llll}1078 & 1070 & 1061 & 1052\end{array}$

$\begin{array}{llll}3158 & 3209 & 3218 & 3253\end{array}$

$\begin{array}{llll}1078 & 1070 & 1061 & 1052\end{array}$
Nat. Gas (\$/therm): $\quad 0.75$

Electricity (\$/kWh): 0.0628

\% Saved from Base Case

\begin{tabular}{crrr} 
Year 5 & 1 Tree & 2 Tree & 3 Tree \\
\cline { 2 - 4 } & -0.56 & -0.7 & -0.9 \\
& 1.78 & 3.12 & 3.31 \\
& 0.04 & 0.27 & 0.18 \\
Year 10 & 0.95 & 1.25 & 1.26 \\
& -0.73 & -0.98 & -1.41 \\
& 3.91 & 7.07 & 8.02 \\
& 0.46 & 1.08 & 1 \\
Year 15 & 3.92 & 6.67 & 6.67 \\
& -0.87 & -1.23 & -1.88 \\
& 5.78 & 10.01 & 11.75 \\
& 0.83 & 1.64 & 1.6 \\
Year 20 & 6.87 & 11.23 & 11.23 \\
& -0.9 & -1.29 & -1.98 \\
& 0.14 & 10.47 & 12.43 \\
& 0.9 & 1.72 & 1.71 \\
& 7.35 & 11.98 & 11.98 \\
\hline
\end{tabular}

1991 \$ Saved from Base Case

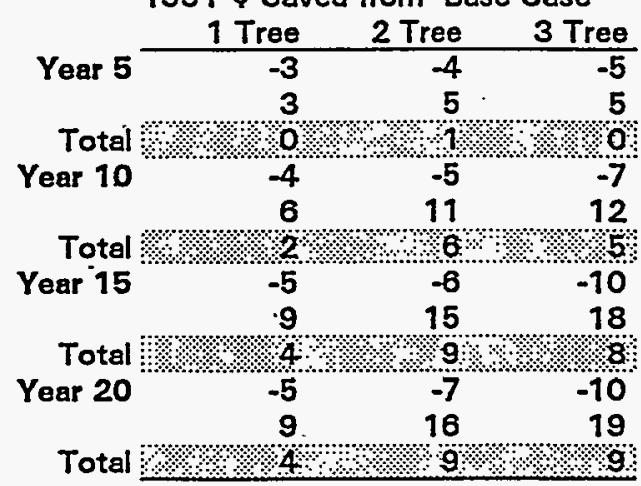

Total

\begin{tabular}{cccr} 
Year 5 & \multicolumn{3}{c}{ \% Saved from Base Case } \\
\cline { 2 - 4 } & 1 Tree & 2 Tree & 3 Tree \\
\hline-0.53 & -1.61 & -1.61 \\
0.82 & 0.82 & 0.82
\end{tabular}

Year 10

$-1.35 \quad-1.61 \quad-2.18$

Year 15

$\begin{array}{lll}0.82 & 1.59 & 1.59\end{array}$

Year 20

$\begin{array}{lll}-1.61 & -1.88 & -2.71\end{array}$

$\begin{array}{lll}0.82 & 1.59 & 2.47\end{array}$

$\begin{array}{lll}-1.61 & -1.88 & -3\end{array}$

\begin{tabular}{lll}
0.82 & 1.59 & 2.41 \\
\hline
\end{tabular} 
Annual Dollar Savings From Base Case

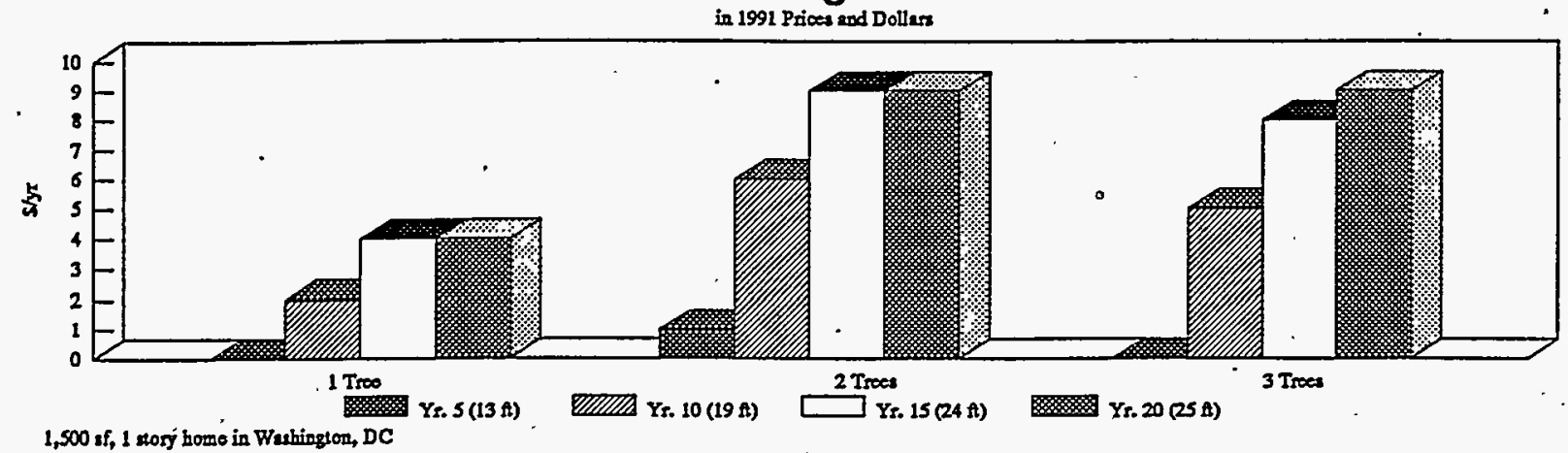
1,500 \&f, 1 norg home in Wushington, DC

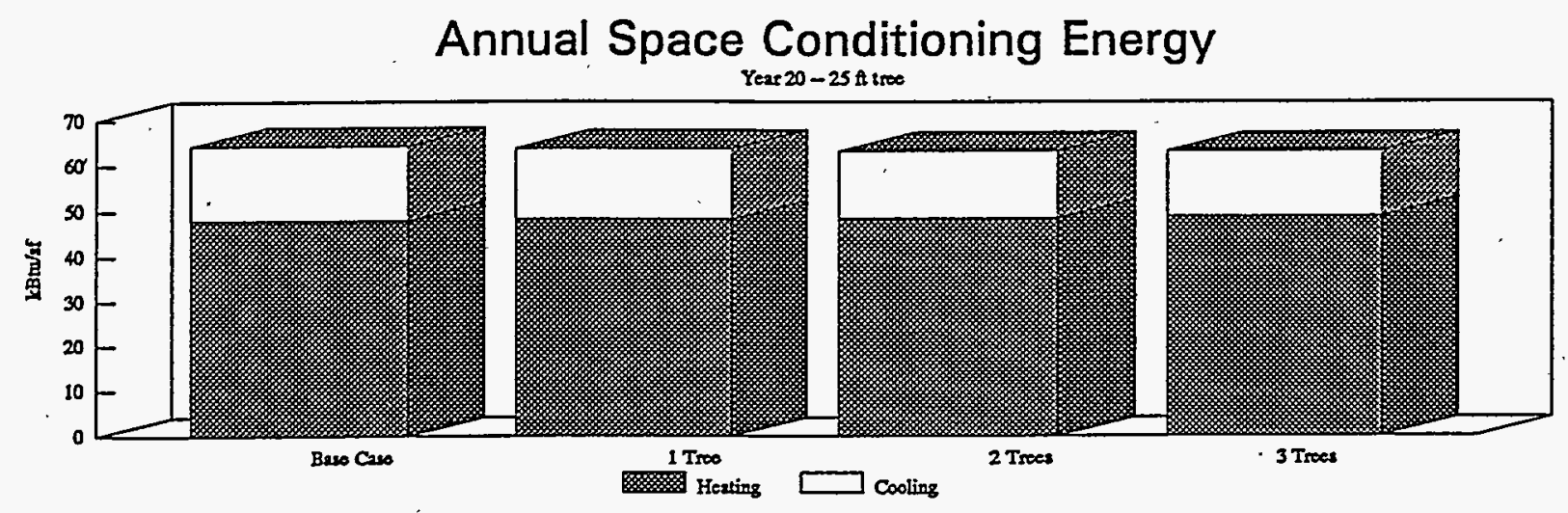

Annual Cooling Savings from Base Case

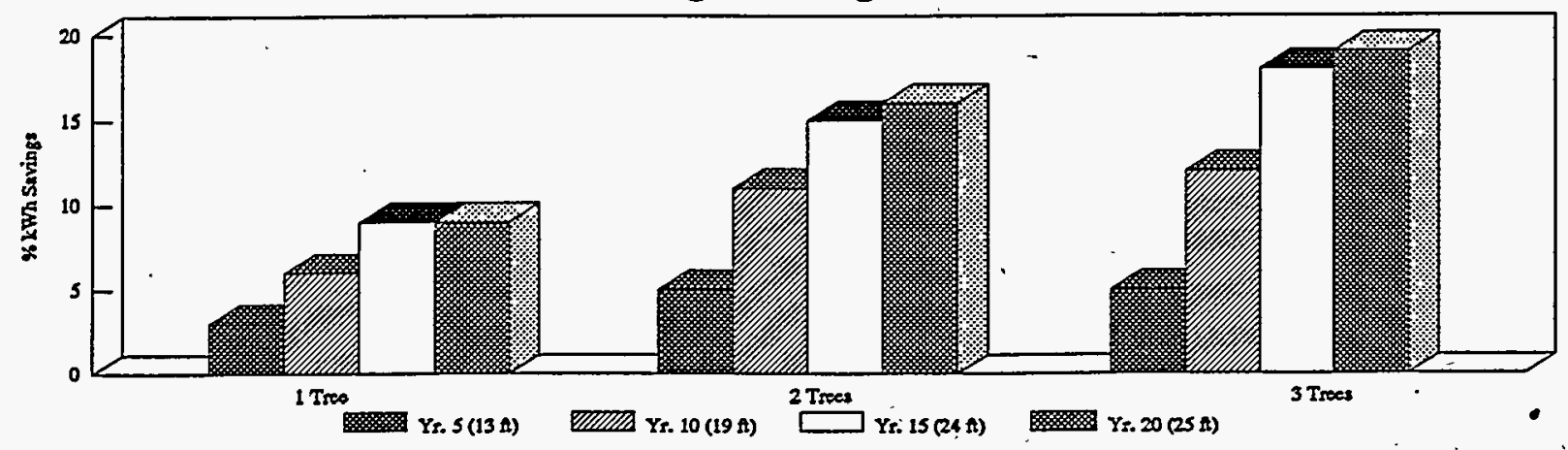

Peak Cooling Savings from Base Case

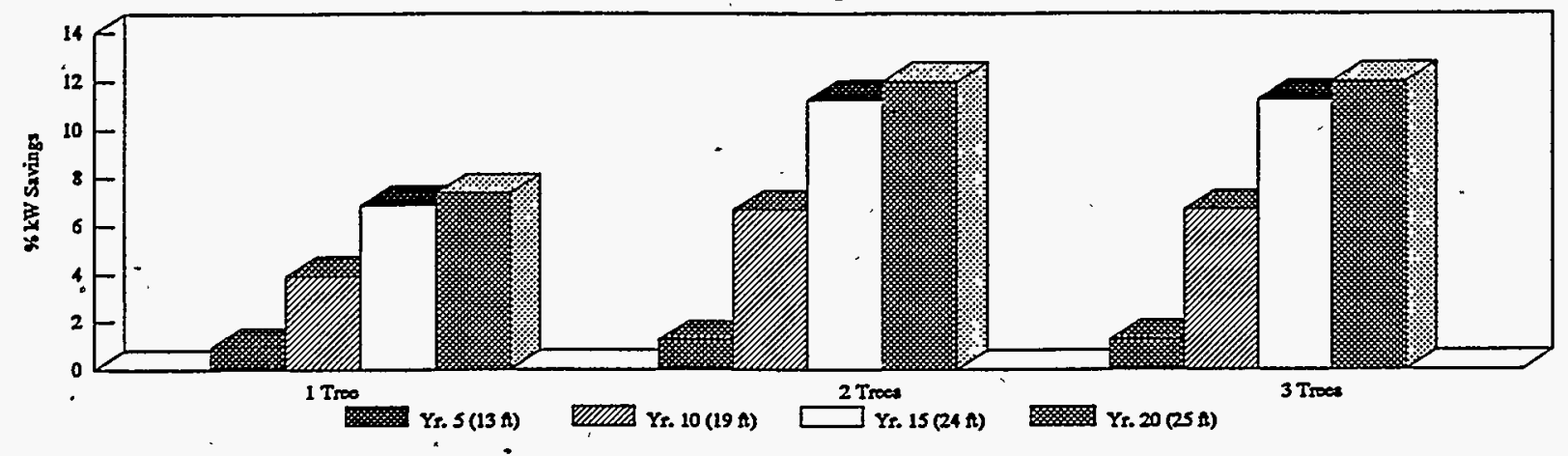


- Washington, DC

2 Story $-1,761 \mathrm{sq} f t$ Residence

Space Conditioning Source Energy Use (kBtul sq ft)

Year 5

Total Heating Use

Total Cooling Use

Total Energy Use

Peak Cool (kW)

Year 10

Total Heating Use

Total Cooling Use

Total Energy Use

Peak Cool (kW)

Year 15

Total Heating Use

Total Cooling Use

Total Energy Use

Peak Cool (kW)

Year 20

Total Heating Use

Total Cooling Use

Total Energy Use

Peak Cool (kW)

Annual Energy Use

\section{Year 5}

Heating (kBtu)

Cooling (kWh)

Year 10

Heating (kBtu)

Cooling (kWh)

Year 15

Heating (kBtu)

Cooling (kWh)

Year 20

Heating (kBtu)

Cooling (kWh)
Tree Shade Only

\begin{tabular}{rrrr} 
Base Case & 1 Tree & 2 Tree & 3 Tree \\
\hline 38.58 & 38.66 & 38.68 & 38.73 \\
13.81 & 13.64 & 13.52 & 13.49 \\
52.39 & 52.31 & 52.20 & 52.22 \\
5.04 & 5.03 & 5.02 & 5.02
\end{tabular}

38.58

13.81

52.39

5.04

38.72

13.34

52.05

4.92

38.78

12.94

51.72

4.81

38.58

13.81

38.77

52.39

5.04

12.95

51.72

4.74

38.87

12.34

51.21

4.55

38.58

13.81

52.39

5.04

38.78

12.87

51.65

4.70

38.89

12.23

51.12

4.53

38.90

12.79

51.69

4.81

39.08

12.05

51.13

4.55

39.11

11.90

51.01

4.53

Nat. Gas (\$/therm):

Electricity (\$/kWh): 0.0628

\% Saved from Base Case

Year 5

\begin{tabular}{crrr} 
Year 5 5 & 1 Tree & 2 Tree & 3 Tree \\
\cline { 2 - 4 } & -0.22 & -0.27 & -0.39 \\
& 1.23 & 2.16 & 2.36 \\
& 0.17 & 0.37 & 0.34 \\
& 0.2 & 0.4 & 0.41
\end{tabular}

Year 10

Year 15

$\begin{array}{rrr}-0.36 & -0.52 & -0.84 \\ 3.46 & 6.31 & 7.41 \\ 0.64 & 1.28 & 1.34 \\ 2.46 & 4.68 & 4.69\end{array}$

\begin{tabular}{rrrr} 
& -0.5 & -0.76 & -1.3 \\
& 6.23 & 10.66 & 12.79 \\
& 1.28 & 2.25 & 2.41 \\
Year 20 & 5.93 & 9.8 & 9.81 \\
& & & \\
& -0.53 & -0.8 & -1.39 \\
& 6.83 & 11.45 & 13.87 \\
& 1.41 & 2.43 & 2.63 \\
& 6.85 & 10.26 & 10.27 \\
\hline
\end{tabular}

1991 \$ Saved from Base Case

\begin{tabular}{rrrr} 
Base Case & 1 Tree & 2 Tree & 3 Tree \\
\hline 65329 & 65470 & 65507 & 65583 \\
2376 & 2347 & 2325 & 2320 \\
& & & \\
65329 & 65566 & 65670 & 65877 \\
2376 & 2294 & 2226 & 2200 \\
& & & \\
65329 & 65656 & 65823 & 66178 \\
2376 & 2228 & 2123 & 2072 \\
& & & \\
65329 & 65673 & 65854 & 66238 \\
2376 & 2214 & 2104 & 2046 \\
\hline
\end{tabular}

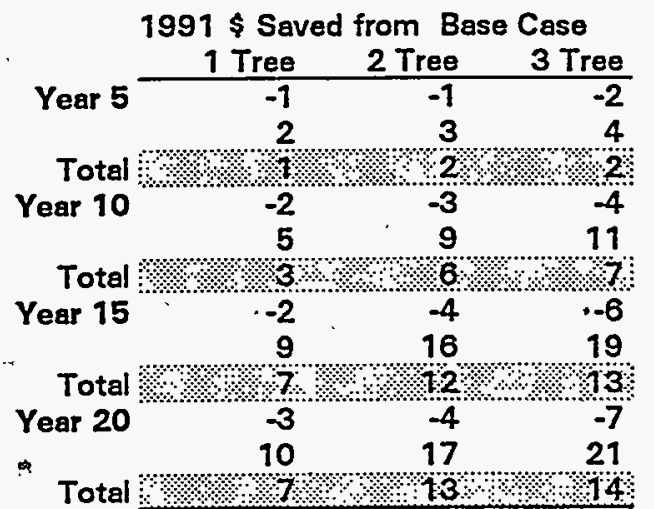

Heating and Air Conditioning Hours of Use

Year 5

Heating (hrs)

Cooling (hrs)

Year 10

Heating (hrs)

Cooling (hrs)

Year 15

Heating (hrs)

Cooling (hrs)

Year 20

Heating (hrs)

$\frac{\text { Base Casa }}{2830}$

\begin{tabular}{cccc} 
Case & 1 Tree & 2 Tree & 3 Tree \\
\hline 2830 & 2830 & 2830 & 2830 \\
1167 & 1167 & 1167 & 1167
\end{tabular}

$\%$ Saved from Base Case

\begin{tabular}{rrrr} 
Year 5 & 1 Tree & 2 Tree & 3 Tree \\
\hline 0 & 0 & 0 \\
0 & 0 & 0
\end{tabular}

Year 10

$\begin{array}{llll}2830 & 2830 & 2839 & 2839\end{array}$

$\begin{array}{llll}1167 & 1158 & 1158 & 1150\end{array}$

Year 15

$\begin{array}{rrr}0 & -0.33 & -0.33 \\ 0.71 & 0.71 & 1.47\end{array}$

$\begin{array}{llll}2830 & 2830 & 2848 & 2865\end{array}$

$\begin{array}{llll}1167 & 1158 & 1158 & 1132\end{array}$

Cooling (hrs)

$\begin{array}{lllll}2830 & 2839 & 2848 & 2873\end{array}$

$\begin{array}{llll}1167 & 1158 & 1158 & 1132\end{array}$

Year 20

$\begin{array}{rrr}0 & -0.63 & -1.22\end{array}$

$-0.33 \quad-0.63 \quad-1.51$
0.71 


\section{Annual Dollar Savings From Base Case}

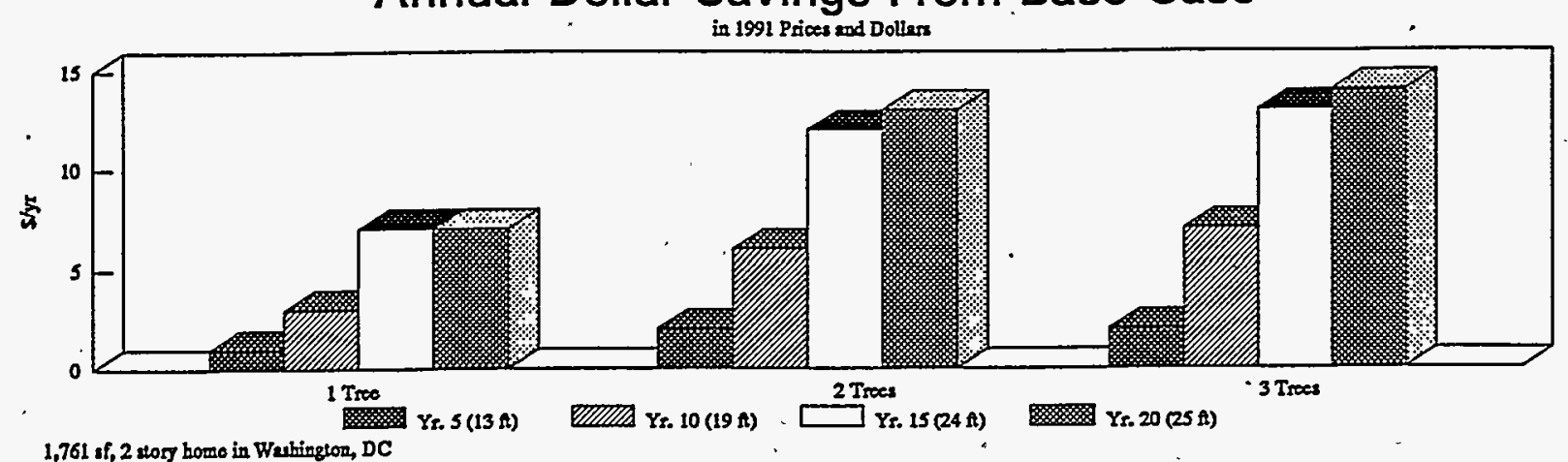

Annual Space Conditioning Energy

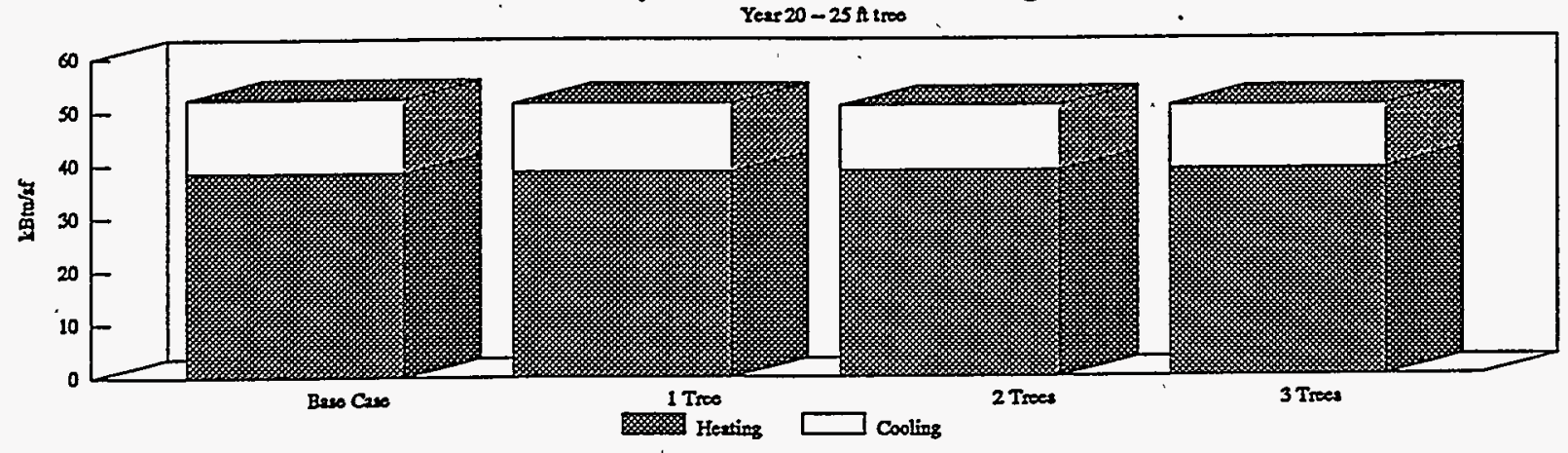

Annual Cooling Savings from Base Case

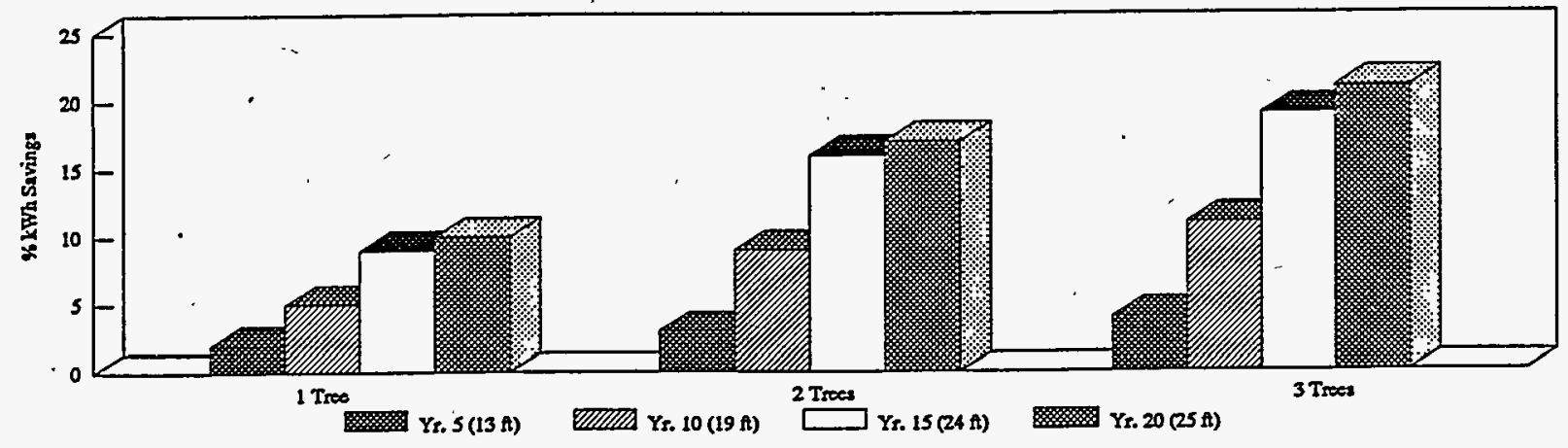

Peak Cooling Savings from Base Case

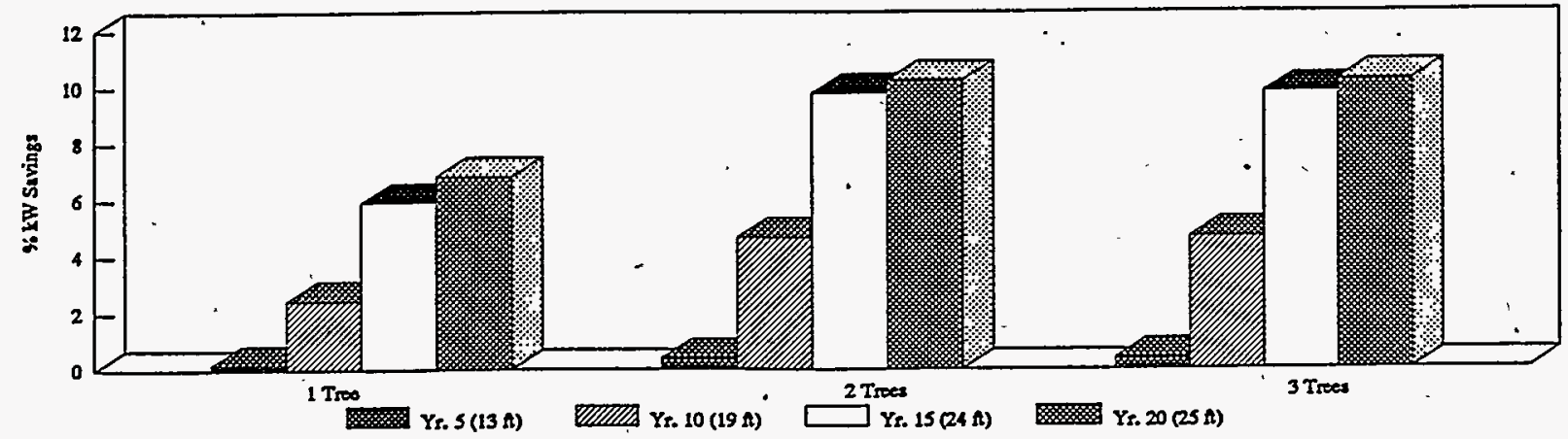


Interim Report

Modeling Benefits and Costs of Community Tree planting:

A Demonstration Project - Phase 1

\title{
by
}

E. Gregory MaPherson, PhD USDA Forest Service

Northeastern Forest Experiment Station

5801 N. Pulaski

Chicago, II 60646

(312) $539-1363$

with

Judy Ratilff

Huan-kil Jo

Graduate Research Assistants

University of Arizona

\author{
to: \\ American Forestry Association \\ U.S. Environmental Protection Agency \\ U.S. Department of Energy \\ U.S.D.A. Forest Service
}

December, 1991 
Introduction . . . . . . . . . . . . . . . . . . . 3

Background and Approach . . . . . . . . . . . . . . . . 4 4

Phase 1 objectives . . . . . . . . . . . . . . . . . . 5

Procedures . . . . . . . . . . . . . . . . . . . . . 6

Demonstration Cities ...................... 6

Procedures for the Interpretation and Analysis of Aerial Photographs ....................... 7

Procedures for Estimating Future Tree Numbers, Cover, and stocking ....................... 9

Procedures for collecting Information on Tree Planting and other

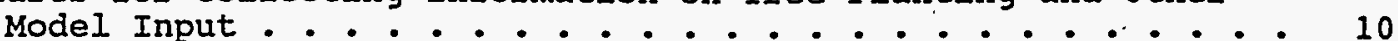

Interim Findings . . . ......................... . 11

Atlanta . . . . . . . . . . . . . . . . . . . . . . . . ..... 11

Boston . . . . . . . . . . . . . . . . . . . . . . . . . . . . . 13

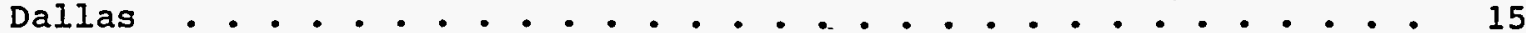

Denver . . . . . . . . . . . . . . . . . . . . . . . . . . . . . 17

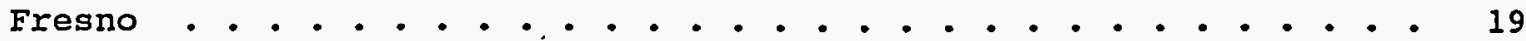

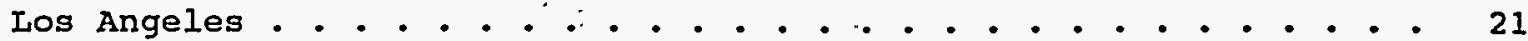

Miami . . . . . . ... . . . . . . . . . . . . . . . . . . . . 23

Minneapolis . . . . . . . . . . . . . . . . . . . . . . . . . . . . 25

Portland ... . . . . . . . . . . . . . . . . . . . . . . . . . . 27

Rock Valley, Iowa . . . . . . . . . . . . . . . . . . . . . . . . . 29

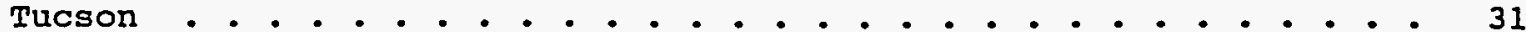

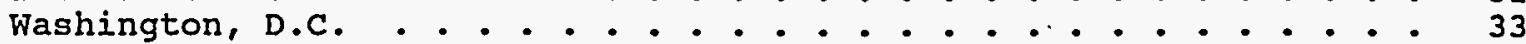

Appendix A - Tree Data . . . . . . . . . . . . . . . 35

Appendix B - Utility Data . . . . . . . . . . . . . . . . 47

Appendix C - Environmental Data ................ 50

References . . . . . . . . . . . . . . . . . . . . 53 


\section{Introduction}

This is an interim report that presents data collected for subsequent use to quantify and monetize benefits and costs associated with tree plantings planned in 12 U.S. cities. Two types of information have been collected in Phase 1 of this study: 1) data regarding the extent of tree cover and opportunity for additional tree planting, and 2) data regarding the numbers,. locations, and species of proposed plantings, objectives of local planting programs, and other input for modeling environmental benefits and management costs. These data will be used in Phase 2 to model the 30-year flow of benefits and costs for tree planting in each city. Phase 2 findings will be used for the following purposes:

- by national and local policy-makers to evaluate the net benefits from large-scale tree plantings in cities throughout the U.S.

- by local non-profits and state and municipal foresters to compare the cost-effectiveness of plantings in different locations,

- by electric utilities, air and water resource planners, and others to assess the potential of tree plantings for energy conservation, air pollution mitigation, stormwater management, and other environmental benefits,

- by urban forest managers to plan budgets for tree care that is needed. to sustain a healthy, functioning urban forest.

Both phases of this study are administered by the American Forestry Association, with funding provided by the U.S. Environmental Protection Agency, the U.S. Department of Energy, and the U.S. Forest Service; Cooperative Forestry. Phase 2 will be completed in December, 1992.

This report begins with an overview of the project's purpose and approach. Specific objectives of Phase 1 are presented, followed by a description of the methods used to accomplish each task. Findings pertaining to urban forest cover, tree planting programs, and other tree-related data are presented for each city, alphabetically. Data regarding tree planting plans, utilities, and environmental benefits are presented in a series of tables that follow. Although it is tempting to begin making analytical comparisons across cities, that is not the purpose of this report. Rather, this paper documents initial work for the purpose of review and comment by those who provided information and others who may use the findings of the benefit-cost analysis that will follow. Please address any, comments regarding these initial findings to the senior author in Chicago as soon as possible. 
Background and Approach

Citizens in communities throughout the United states are planning and implementing large-scale reforestation efforts to mitigate urban heat islands, offset carbon dioxide emissions, and beautify their communities. However, volunteer tree planting efforts may be hampered by the lack of urban forestry planning tools that citizens and professionals can use to develop realistic planting goals, identify the resources needed to achieve these goals, and evaluate the appropriateness of different tree species. The primary purpose of this project is to demonstrate application of an existing benefit-cost analysis model (McPherson, 1991) for evaluation and planning of urban forestry projects in selected communities throughout the U.S. A second goal is to quantify the potential heating and cooling energy savings associated with typical yard tree plantings in different climatic regions. Findings from the study will directly benefit the case study communities, and indirectly assist other communities with similar tree species, growing conditions, and envirónmental concerns related to energy/water/carbon dioxide conservation, air quality, stormwater management, etc. Experience gained from this demonstration project could also assist future technology transfer efforts aimed at promoting optimal planting configurations and developing a "userfriendly" workbook and computer program for distribution to states and cities.

Urban greenspace provides many environmental and social services that contribute to the quality of life in cities. Traditional economic approaches used to estimate the value of greenspace services (e.g., travel cost, willingness to pay, hedonic pricing, tree valuation) have limited utility to policy-makers, planners, and managers because the underlying values they estimate only indirectly reflect the flow of multiple benefits and costs. This deficiency is partially addressed by the accounting approach used in this project, which connects vegetation structure with the spatial-temporal flow of functional benefits and costs. Prices are assigned to each cost (i.e., planting, pruning, removal, irrigation) and benefit (i.e., heating/cooling energy savings, air pollution absorption, stormwater runoff reduction) through direct estimation and implied valuation of benefits as environmental externalities.

This accounting approach makes it possible to model the net benefits of plantings in different locations and with different species. Trees planted in yards, parks, streets, and unimproved lands are likely to have different rates of growth and mortality, as well as different levels of maintenance. Futhermore, functional benefits can vary with location. Yard trees will shade homes more than park or street trees will. Another unique aspect of the approach is the direct connection of selected benefits and costs with leaf area. Because many functional benefits of trees are related to leafatmosphere processes (e.g., interception, transpiration, photosynthesis), benefits increase as leaf surface area increases. Similarly, pruning and removal costs usually increase with tree size. To account for this timedependent relationship, benefits and costs are assumed to be linearly related to leaf area. Hence, this approach "grows trees" in different locations and directly calculates the annual flow of benefits and costs as trees mature and die. Therefore, information regarding growth, mortality, and leaf area of different tree species in different types of locations is fundamental to the Phase 2 benefit-cost analysis.

This greenspace accounting approach uses direct estimation to account for the effects of trees on energy use for heating and cooling buildings. Computer simulation is used to quantify energy savings due to shading, temperature modification, and wind speed reductions from trees. Implied valuation is used to estimate the societal benefit of reducing air pollution and stormwater runoff.' Implied valuation relies on the costs of required or 
anticipated environmental control measures or regulations to estimate tree benefits. For instance, if society is willing to pay $\$ 1$ per $1 b$ for current or planned air pollution control, then a tree that absorps or intercepts 1 lb of pollution should also be worth $\$ 1$.

clearly, as city dwellers become increasingly concerned with quality of life issues, monetizing the environmental beriefits of urban forests puts trees on more equal standing with other capital investment options. This approach also increases the status of trees relative to other investments in urban infrastructure and high-tech environmental controls because trees become more cost-effective as they grow larger. All infrastructure-improvements depreciate as they age, and many traditional controls become progressively less efficient as they age -- especially compared to healthy, long-lived trees.

\section{Phase 1 objectives}

Work on Phase 1 has been conducted between January 1, 1991 and December 31,1991 to achieve the following objectives:

1. Choose cities for demonstration that have the greatest relevance for the greatest number of people.

2. Determine existing urban forest stocking levels for yards, streets, parks, and unimproved lands in each city using aerial photograph interpretation.

3. Identify existing tree planting programs, goals, and objectives for each city, as well as issues of local and regional importance that tree planting addresses.

4. Collect data that will be used as input to the benefit-cost analysis model (e.g., expected tree growth rates, mortality, pruning costs and frequency, removal costs, climatic data, water and energy prices, and traditional control costs for air pollution and stormwater runoff control). 


\section{Procedures}

\section{Demonstration Cities}

Twelve demonstration cities have been selected based on a method that aggregated population centers into similar climatic regions (Andersson et al. 1986). The objective in selecting cities was to choose ones with the greatest relevance for the greatest number of people. Both major centers of population and significant types of climate were considered. Population centers used in the eleven regions identified by Andersson and others (1986) were largely adopted for this study (Table 1). However, some cities were substituted (e.g., Tucson for Phoenix) and Rock Valley, Iowa was added because of its unique Energy Efficiency Research Project (Fig. 1).

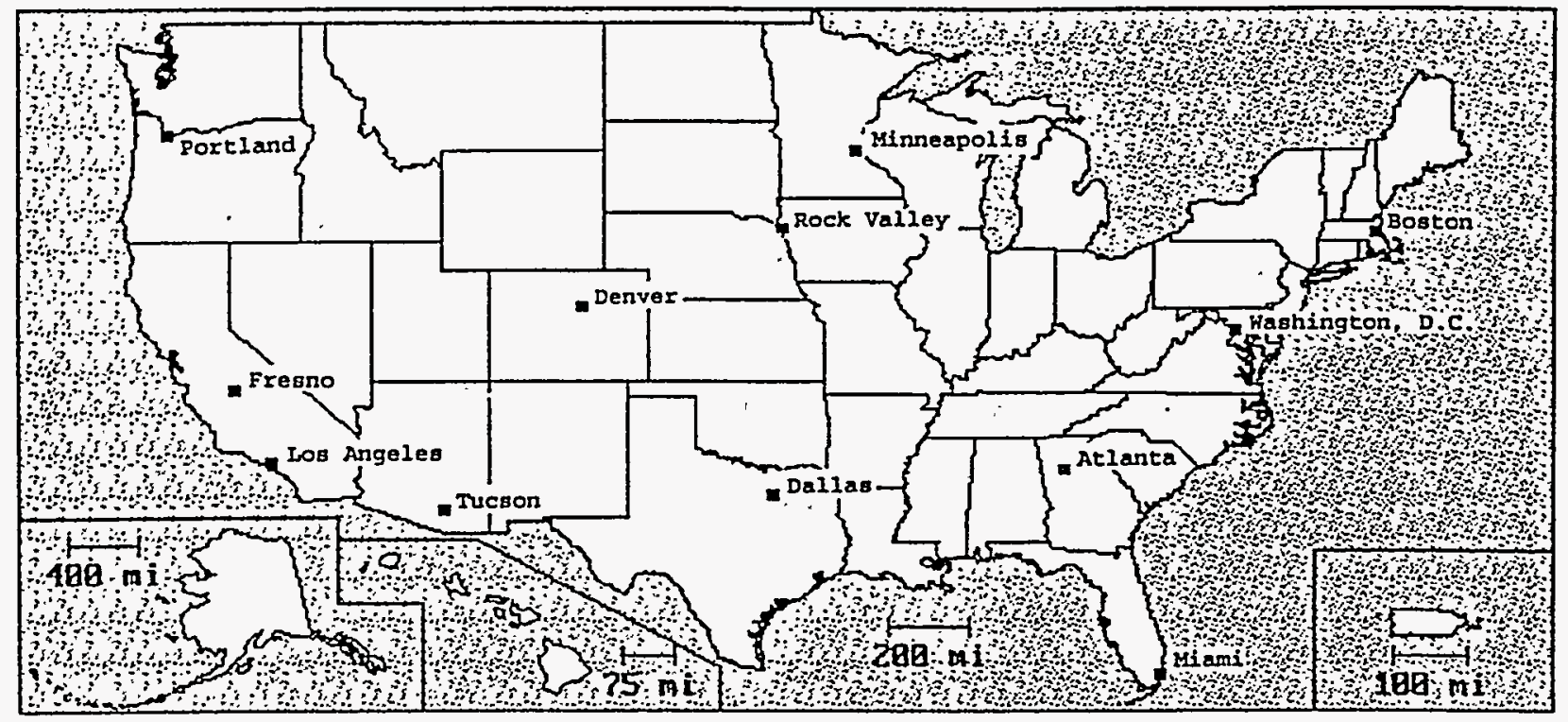

Figure 1. Locations of 12 demonstration cities. 
Table 1

Demonstration Cities

\begin{tabular}{|c|c|c|c|c|c|c|}
\hline $\begin{array}{c}\text { Region/ } \\
\text { Demo City }\end{array}$ & $\begin{array}{l}\text { Pop. } \\
(1000 s)\end{array}$ & $\begin{array}{c}\text { Area } \\
\text { (sq } \\
\text { miles) }\end{array}$ & $\begin{array}{l}\text { Street } \\
\text { Length } \\
\text { (miles) }\end{array}$ & $\begin{array}{c}\text { Heating } \\
\text { Degree } \\
\text { Days }\end{array}$ & $\begin{array}{c}\text { Cooling } \\
\text { Degree } \\
\text { Days }\end{array}$ & $\begin{array}{c}\text { Annual } \\
\text { Rain } \\
\text { (in) }\end{array}$ \\
\hline $\begin{array}{l}\text { South/ } \\
\text { Atlanta }\end{array}$ & 437 & 132 & 1,410 & 3,094 & 1,588 & 49 \\
\hline $\begin{array}{c}\text { Great Lakes-NE/ } \\
\text { Boston }\end{array}$ & 520 & 46 & 836 & 5,593 & 699 & 44 \\
\hline $\begin{array}{c}\text { Central Texas/ } \\
\text { Dallas }\end{array}$ & 1,000 & 331 & 3,400 & 2,335 & 2,670 & 29 \\
\hline $\begin{array}{c}\text { Mountains/ } \\
\text { Denver }\end{array}$ & 468 & 155 & 1,564 & 6,016 & 625 & 15 \\
\hline $\begin{array}{l}\text { Semi/Arid/ } \\
\text { Fresno }\end{array}$ & 418 & 113 & 1,478 & 2,650 & 1,670 & 11 \\
\hline $\begin{array}{l}\text { Calif. Coast/ } \\
\text { Los Angeles }\end{array}$ & $\cdot 3,485$ & 467 & 7.000 & 1,818 & 614 & 12 \\
\hline $\begin{array}{c}\text { Gulf Coast/ } \\
\text { Miami }\end{array}$ & 359 & 35 & .792 & 205 & 4,037 & 58 \\
\hline $\begin{array}{l}\text { Northern Tier/ } \\
\text { Minneapolis }\end{array}$ & 375 & 59 & 1,000 & 8,007 & 662 & 26 \\
\hline $\begin{array}{l}\text { Pacific NW/ } \\
\text { Portland }\end{array}$ & 440 & 137 & 1,638 & 4,792 & 299 & 37 \\
\hline $\begin{array}{c}\text { Great Lakes-NE/ } \\
\text { Rock Valley }\end{array}$ & 3 & 1 & 13 & 6,601 & 949 & 30 \\
\hline $\begin{array}{l}\text { Desert SW/ } \\
\text { Tucson }\end{array}$ & 405 & 158 & 1,409 & 1,734 & 2,840 & 11 \\
\hline $\begin{array}{l}\text { Northeast/ } \\
\text { Washington DC }\end{array}$ & 623 & 69 & 1,157 & 5,008 & 940 & 39 \\
\hline
\end{tabular}

Procedures for the Interpretation and Analysis of Aerial Photographs

Collection of tree canopy cover data was undertaken using aerial photographs for two reasons. First, to estimate available growing space, existing canopy cover, and tree stocking levels for four types.of landscapes used in the benefit-cost model: park, yard, street, and unimproved lands. second, these data are used to initially estimate the impact of proposed plantings on tree numbers, cover, and stocking for each landscape-type. 
Information collected from the aerial photographs could be used in subsequent research to explore relations between vegetation cover, other types of land cover, land use, and demographic variables (e.g., ethnicity, economic status, education, etc.) within the demonstration cities and across regions of the U.S.

The methods used to acquire tree canopy cover data in this project are based on previous urban forest inventory work described by Miller (1988) and Nowak (1991). Available growing space is defined as the percentage of total city area that is covered by tree/shrub and grass/soil cover types. stocking levels are calculated as the percentage of total available growing space with tree/shrub canopy cover.

Sampling from aerial photographs. Procedures followed to estimate tree cover are outlined below.

1. Black and white aerial photographs were obtained with a preferred scale of about $1^{\prime \prime}=500^{\circ}(1: 6,000)$. Relatively recent imagery with trees in-leaf was desired. Because of budget restrictions on both the cost of photos and time spent interpreting the photos, it was not possible to completely sample each city. Hence, the extent of analysis varies among cities (see Table 2).

2. Census tract boundaries were outlined on the aerial photographs.

3. An acetate I" by I" dot grid was placed on the aerials for interpretation. This resolution is a compromise between the competing concerns for data reliability (i.e., a large sample size) and the availability of time and money. For a typical urban census tract that is $1 \mathrm{sq}$ mile in size, this resolution provides 110 data points. In most cases, where coverage of the city was complete, we sampled every third census tract so as to include all parts of the city.

4. The appropriate land use/land cover designation for each dot was marked on a census tract tally sheet. Note that general landscape-locations (park, yard, street, and unimproved land) are included for the tree/shrub and grass/soil cover types. These locations imply different types of growing conditions, mortality, and maintenance. For example, streét trees may be planted and pruned by city arborists, while yard trees are cared for by residents. This distinction permited calculation of stocking levels by location.

5. We estimated stocking levels for residential streets by randomly selecting a grid point within the census tract and locating the nearest residential street intersection (adjacent land use is predominately residential). We counted the number of streetside trees (both sides of the street) for 1,250 ft (2.5 in) in opposite directions from the intersection ( 5 inches or $2,500 \mathrm{ft}$ total). This process was repeated for the remaining street so that the entire sample is $5,000 \mathrm{ft}$ long or 10 inches. We recorded tree numbers on the tally sheet and calculated stocking levels assuming full stocking is 2 trees per 50 linear ft of street. This procedure amounts to sampling of about 1 linear mile of street, or 108 of a typical urban census tract's 10 linear miles of street.

Land use and land cover types. Land cover and land use designations used in this study are based on those used in previous work by Forest service scientists (Rowntree, 1984; Nowak, 1991). Five land cover types were identified: tree/shrub, grass/soil, building, paving, and water. The tree/shrub and grass/soil cover types were further subdivided by location into park, yard, street, and unimproved land.

Land use categories included: residential (1-2 family), residential (multifamily), industrial/commercial, institutional (e.g., schools, hospital, . 
government, golf courses, cemeteries), transportation (e.g., freeways, airports, railyards), park, vacant, and miscellaneous.

Information on the imagery and sampling intensity for each demonstration city is shown in Table 2. We were unable to use census tracts as the sampling unit in Los Angeles because they were being redrawn at the time of our work.

Table 2

Aerial Photograph Sampling Information

\begin{tabular}{|c|c|c|c|c|c|c|c|c|}
\hline $\begin{array}{l}\text { Demo } \\
\text { Cities }\end{array}$ & $\begin{array}{l}\text { Total } \\
\text { Census } \\
\text { Tracts }\end{array}$ & $\begin{array}{l}\text { Census } \\
\text { Tracts } \\
\text { Sample }\end{array}$ & $\begin{array}{c}\text { C.T. } \\
\text { Sampled } \\
\overline{8}\end{array}$ & $\begin{array}{l}\text { Points } \\
\text { Sampled } \\
n\end{array}$ & $\begin{array}{l}\text { Photo } \\
\text { Scale } \\
\text { in:ft }\end{array}$ & $\begin{array}{c}\text { Photo } \\
\text { Date } \\
\text { mt/yr }\end{array}$ & $\begin{array}{l}\text { Census } \\
\text { Tract } \\
\text { Location }\end{array}$ & $\begin{array}{c}\text { C.T. } \\
\text { Sample } \\
\text { Freq. }\end{array}$ \\
\hline Atlanta & 114 & 25 & 21.9 & 4,520 & $1: 400$ & $2 / 89$ & $\begin{array}{c}\text { Central, } \\
N \cdot \& S W\end{array}$ & $\begin{array}{l}\text { every } \\
\text { third }\end{array}$ \\
\hline Boston & 161 & 29 & 18.0 & 1,255 & $1: 200$ & $\begin{array}{c}\text { win/ } \\
80\end{array}$ & Central & $\begin{array}{l}\text { every } \\
\text { other }\end{array}$ \\
\hline Dallas & -274 & 35 & 12.8 & 5,098 & $1: 400$ & $4 / 85$ & $\begin{array}{l}\mathrm{N} \text { to } \mathrm{s} \\
\text { belt, } \mathrm{CBD}\end{array}$ & $\begin{array}{l}\text { every } \\
\text { third }\end{array}$ \\
\hline Denver & 136 & 50 & 36.8 & 3,658 & $1: 500$ & $11 / 88$ & All & $\begin{array}{l}\text { every } \\
\text { third }\end{array}$ \\
\hline Fresno & 88 & 29 & 33.0 & 5,900 & $1: 400$ & $8 / 90$ & All & $\begin{array}{l}\text { every } \\
\text { third }\end{array}$ \\
\hline $\begin{array}{l}\text { Los } \\
\text { Angeles }\end{array}$ & $\begin{array}{l}467 \mathrm{sq} \\
\text { miles }\end{array}$ & $\begin{array}{l}115 \mathrm{sq} \\
\text { miles }\end{array}$ & 25.0 & $.20,095$ & $1: 400$ & $1 / 84$ & $\begin{array}{l}\text { North, } \\
\text { Northwest }\end{array}$ & $\begin{array}{l}\text { every } \\
\text { third }\end{array}$ \\
\hline Miami & 262 & 33. & 12.6 & 1,331 & $1: 300$ & $12 / 90$ & $\begin{array}{l}\text { Central } \\
\& \text { North }\end{array}$ & $\begin{array}{l}\text { every } \\
\text { one }\end{array}$ \\
\hline $\begin{array}{l}\text { Minnea- } \\
\text { polis }\end{array}$ & 124 & 8 & 6.5 & 500 & $1: 100$ & $4 / 88$ & $\begin{array}{l}\text { Partial N } \\
\text { Partial S }\end{array}$ & $\begin{array}{l}\text { every } \\
\text { one }\end{array}$ \\
\hline $\begin{array}{l}\text { Port- } \\
\text { land }\end{array}$ & 313 & 37 & 11.8 & 5,823 & $1: 400$ & $6 / 90$ & $\begin{array}{l}\text { Part NW \& } \\
\text { S,Central }\end{array}$ & $\begin{array}{l}\text { every } \\
\text { third }\end{array}$ \\
\hline $\begin{array}{l}\text { Rock } \\
\text { Valley }\end{array}$ & 1 & 1 . & 100.0 & 725 & $1: 400$ & $\begin{array}{l}\text { sum/ } \\
. ? 3\end{array}$ & All & $\begin{array}{l}\text { every } \\
\text { one }\end{array}$ \\
\hline Tucson & 117 & 28 & 23.9 & 6,456 & $1: 400$ & $3 / 90$ & All urban & $\begin{array}{l}\text { every } \\
\text { third }\end{array}$ \\
\hline $\begin{array}{l}\text { Wash. } \\
\text { D.C. }\end{array}$ & 192 & 51 & 26.6 & 2,147 & $1: 200$ & $3 / 81$ & All, part & $\begin{array}{l}\text { every } \\
\text { other }\end{array}$ \\
\hline
\end{tabular}

Procedures for Estimating Future Tree Numbers, Cover, and Stocking

Initial estimates of the impacts of proposed plantings on tree numbers, cover, and stocking were calculated, although more detailed projections will be developed during Phase 2 of this study. Estimates were derived for the year 2020 , or about 30 years from now, but based on the number of trees expected to be planted in each city during the next five years. Tree mortality rates for the 30 -year period were assumed to vary with location: park $=308$, yard $=20 \%$, street $=408$, and unimproved land $=308$. Also, mature tree crown width and resulting individual tree crown cover was assumed to vary with location: park $=50 \mathrm{ft}$, yard $=40 \mathrm{ft}$, street $=30 \mathrm{ft}$, and unimproved land $=40 \mathrm{ft}$. 
Current tree numbers were estimated by dividing canopy cover by individual tree crown cover for each location. Future tree cover due to new plantings was obtained by first reducing the number of trees planted to account for mortality, then multiplying the remaining number of stems in each location by their respective individual tree crown cover. The amount of marginal tree cover from new plantings was added to the existing tree cover to project future tree cover. Hence, it was assumed that mortality within the current urban forest was offset by recruitment, so that there is no net change except for specified new tree plantings. Future stocking levels were estimated by dividing future tree cover by current available growing space.

It should be noted that these findings are rough preliminary estimates. The estimates rely on data from the aerial photos, whose accuracy and reliability vary from city to city depending on sampling density. Also, they depend on some very general assumptions regarding mature tree size and mortality rates. Thus, these estimates are nothing more than indicators of the potential impact that future tree plantings could have on the extent of each city's urban forest.

Procedures for collecting Information on Tree Planting and other Model Input

Open-ended interviews were used to collect information regarding existing tree planting programs: their current status, partnerships present and planned, and plans for tree planting. Between February and July we interviewed people affiliated with city forestry departments, citizen non-profits, local, regional, and state agencies, tree care firms, nurseries, developers, and utilities. Follow-up phone calls and correspondance were used to obtain missing data and for clarification. "During interviews we determined the number of trees to be planted during the next five years in park, yard, street, and unimproved lands. We inquired as to the reasons for planting and what groups would be involved in the planting and maintenance of trees. More specific information was obtained regarding species, sizes, planting costs, maintenance plans/costs, and expected growth and survival rates. Appendix A contains tables with the tree-related data collected for each demonstration city.

Utility-related data was also collected for each city through interviews, phone calls, and correspondance. Specific information requested from water, electric, and natural gas utilities is shown in Appendix B. These data will be used to account for tree impacts on landscape water demand and building energy use.

The EPA Aerometric Information Retrieval system was accessed to determine the number of times federal health standards for carbon monoxide, ozone, and particulates (PMI0) were exceeded from 1985-1990 (Appendix C). Health standards for other air poliutants were generally not exceeded.

officials responsible for managing stormwater runoff were interviewed to determine the extent to which stormwater is regulated and flood control is practiced regionally and on-site. The findings in Appendix $C$ show that flood control is regulated and practiced in all but three cities. Regional retention/detention basins are the most common means of flood control.

Data were collected on control costs for air pollutants and stormwater runoff (Appendix C). The U.S. Environmental Protection Agency provided much of the information regarding air pollution control costs, while some local hydrologists and engineers estimated costs for retention/detention basins. Also, we attempted to obtain data on stormwater treatment costs, but found that this information was unavailable, largely because little stormwater treatment occurs. However, new federal regulations (National Pollutant Discharge Elimination system) governing the quality of runoff have caused many cities to evaluate new methods for regulating runoff and improving its quality. If the costs of stormwater treatment increase and are tractable, then the value of greenspace for water quality improvement will become easier to appraise. 


\section{Interim Findings}

cities.

Interim findings are presented in alphabetical order for the 12 demonstration

\section{Atlanta}

The Atlanta metropolitan area includes parts of 5 counties and is considered one of the most heavily forested urban areas in the country. Current tree cover is about 408 (Fig. 2). Still, over the last several decades, approximately 258 of the forest cover citizens take such pride in has been lost to rapid development and other problems, such as a falling water table. Trees Atlanta, the local non-profit Global Releaf affiliate led by Marcia Bansley, has been at the forefront of turning this deforestation around. The group has worked in conjunction with city, county, and state agencies and has not only seen to the planting of trees but has successfully lobbied for the passage of tree preservation ordinances and new construction planting ordinances.

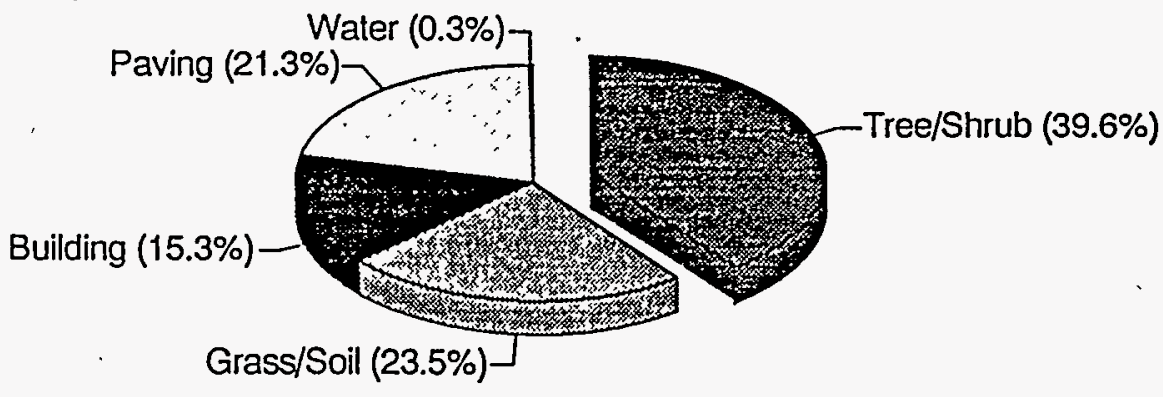

Figure 2. Land cover percentages for Atlanta.

In preparation for the upcoming olympics in 1996, the city's tree planting groups and agencies plan plantings over and above. what might be anticipated in a typical five-year span, especially at olympic venues and at certain key visual impact intersections and interchanges on gateways into and out of town. These projects are being undertaken in addition to ongoing work to (1) plant trees downtown through the cooperation of Trees Atlanta, local business, and government; to (2) continue the city's routine planting of some 2,000 street and park trees per year; and (3) to require installing thousands of new trees each year as part of new construction planting ordinances. It's worth noting that Atlanta's residential neighborhoods are for the most part extremely well-treed (about 638, of full stocking). Therefore, there is not the push for planting neighborhood street trees that is found in many cities. 
Table 3

Initial Estimates of Tree Numbers, Cover, and stocking for Atlanta

\begin{tabular}{lrrrrrrrr}
\hline & $\begin{array}{r}\text { Current } \\
\text { Tree }\end{array}$ & $\begin{array}{r}\text { New } \\
\text { Plant- } \\
\text { ings }\end{array}$ & $\begin{array}{r}\text { Curr } \\
\text { Cover } \\
8\end{array}$ & $\begin{array}{r}\text { Nover } \\
\text { Cover }\end{array}$ & $\begin{array}{r}\text { Cover } \\
\text { Change }\end{array}$ & $\begin{array}{r}\text { Curr } \\
\text { stock }\end{array}$ & $\begin{array}{r}\text { New } \\
\text { stock } \\
8\end{array}$ & $\begin{array}{r}\text { Stock } \\
\text { Change } \\
8\end{array}$ \\
\hline Park & 24,359 & 5,000 & 1.3 & 1.5 & 0.1 & 50.0 & 57.2 & 7.2 \\
Yard & 907,841 & 42,500 & 31.0 & 32.2 & 0.3 & 63.0 & 65.4 & 2.4 \\
Streets & 149,640 & 5,900 & 0.4 & 0.5 & 0 & 50.3 & 51.0 & 0.7 \\
UnImproved & 202,062 & 7,000 & 6.9 & 7.1 & 0.1 & 68.3 & 70.0 & 1.7 \\
Total & $1,283,902$ & 60,400 & 39.6 & 40.2 & 1.6 & 62.8 & 65.3 & 2.5 \\
\hline
\end{tabular}

The office of the Atlanta city forester has; like so many other municipal foresters, suffered cutbacks in recent years. Currently, city forester Jay Lowery is removing approximately 2,700 trees per year from public property and is slated to replace 2,000 of those trees (half in parks and half along streets). New species of trees, such as willow oak, a proven survivor of urban conditions, are replacing old favorites, such as pin oak, for example, which is less tolerant to Atlanta's summertime ozone air pollution. A potential problem is the fact that although the city has pledged to take responsibility for the Trees Atlanta plantings after the establishment period, ongoing budget constraints will likely make this very minimal care.

We estimate that approximately 12,000 trees will be planted yearly during the next five years (Table 3). For simulation purposes, street tree plantings by Trees Atlanta and the city forestry department will be grouped together and costs calculated using a weighted average. Yard trees are assumed to result from the ordinance requiring plantings with new construction. Most of these plantings will occur on private property and many will receive professional care (i.e., as with commercial, industrial, multifamily residential properties). Expressway plantings by the Georgia Department of Transportation will use a variety of plant materials, from $3-4$ ' bare root whips to 3.5 " specimen trees.

Current urban forest stocking levels range from $50 \%$ in parks and streets to 688 in unimproved areas. The proposed plantings account for about 58 of the existing number of trees (1.28 milizion) and will add over 1,300 acres of urban forest.cover. overall stocking will increase by 2.58 , with park tree stocking increasing by 78 (Table 3 ).

Atlanta has been a center of research and debate regarding the role of. vegetation in ozone pollution. Recent findings suggest that the detrimental effects of natural hydrocarbon emissions from trees are more than offset by benefits from lower urban temperatures and ozone absorption by leaves. Because ozone is a problem, future plantings will need to emphasize species with low hydrocarbon emission rates, although this is not widely recognized at present. similarly, the ability of trees to mitigate the urban heat island and thereby lower ozone concentrations was not reported as a reason for tree planting. Jurisdictions in the Atlanta area are very concerned about stormwater management and control of soil erosion. ordinances require retention/detention basins with new development and there are numerous regional basins. 
Boston is a highly urbanized city known for its many beautiful parks and other public greenspace. Not surprisingly, our sample suggests that Boston has ample growing space available for trees (5iz). Currently, grass/soil cover (318) exceeds tree cover (208) (Fig. 3). The Boston Parks and Recreation Department is one of several agencies planting trees within the Boston city limits, others are the Boston Redevelopment Authority, Transportation and Public Facilities Departments, and the Metropolitan District Commission (MDC). Boston also has an active stable of small non-profit groups operating to achieve specific ends, such as the Franklin Park coalition, Friends of Post office Square, the Boston Greenspace Alliance.

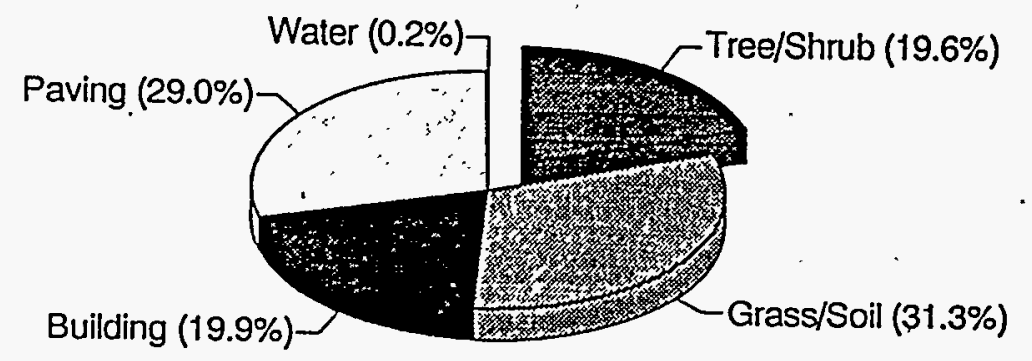

Figure 3. Land cover percentages for Boston.

Like many other cities in this study, Boston is a prime example of a city whose tree program has been all but wiped out over the last decade by budget cuts that were mandated originally by the citizen originated Proposition $21 / 2$. Well-. known budget problems of the past few years led to more budget cuts. However two years ago, the parks department hired Brian Gilbert as its urban forester, realizing that letting the forest slip much more would begin to leave too many dangerous trees along city streets.

Gilbert's first priority has been to see that operating funds (which Gilbert characterizes as 908 under the level to maintain an At department) were spent on much needed tree maintenance for the city's 250,000 public trees. And because the number one request that comes into the department is for residential street trees, the department continues ta plant a few hundred trees per year, which the city maintains after an establishment period. Recently, the numbers of residential street trees being planted have been boosted through funds offered by Massachusetts Releaf, which works directly with municipalities throughout the state (rather than through non-profit groups in each city). Mass Releaf, headed by Jennifer Rooks, sponsors specific projects proposed by. the city's tree wardens. Every Massachusetts city by law has a tree warden to oversee public plantings.

Tree stocking levels range from 258 in unimproved areas to 478 along streets. Based on our interviews, we expect about 1,766 trees to be planted annually in 
Boston during the next five years (Table 4). Yard trees are assumed to be planted on Boston Redevelopment Authority project sites. Trees along arterials are assumed to be planted by the MDC and Transportation Dept. other trees are to be planted by the Parks and Recreation Department. These proposed plantings represent over 38 of the existing 265,000 trees, and will add 141 acres of tree cover. stocking will increase by about $1-28$ in parks and streets.

Table 4

Initial Estimates of Tree Numbers, Cover, and stocking for Boston

\begin{tabular}{lrrrrrrrr}
\hline & $\begin{array}{r}\text { Current } \\
\text { Tree }\end{array}$ & $\begin{array}{r}\text { New } \\
\text { Plant- } \\
\text { ings }\end{array}$ & $\begin{array}{r}\text { Curr } \\
\text { Cover } \\
8\end{array}$ & $\begin{array}{r}\text { New } \\
\text { Cover } \\
8\end{array}$ & $\begin{array}{r}\text { Cover } \\
\text { Change } \\
8\end{array}$ & $\begin{array}{r}\text { Curr } \\
\text { stock } \\
8\end{array}$ & $\begin{array}{r}\text { New } \\
\text { stock } \\
8\end{array}$ & $\begin{array}{r}\text { Stock } \\
\text { Change } \\
8\end{array}$ \\
\hline Park & 30,038 & 1,930 & 4.6 & 4.8 & 0.2 & 33.1 & 34.6 & 1.5 \\
Yard & 147,985 & 1,000 & 14.5 & 14.6 & 0.1 & 41.3 & 41.5 & 0.2 \\
Streets & 83,426 & 5,900 & 0.1 & 0.3 & 0.2 & 47.3 & 48.6 & 1.3 \\
UnImproved & 4,090 & 0 & 0.4 & 0.4 & 0 & 25.1 & 25.1 & 0 \\
Total & 265,539 & 8,830 & 19.6 & 20.1 & 0.5 & 38.5 & 39.4 & 0.9 \\
\hline
\end{tabular}

Perhaps the most important environmental issue tree planting can address in the Boston area is air quality. Both ozone and carbon monoxide have exceeded federal air quality standards. Storm and sanitary sewerage are separate, and stormwater is collected in oversized pipes. Runoff is currently deposited in the ocean without treatment, but new federal regulations may require treatment. 


\section{Dallas}

Dallas was founded in the midst of a hot, dry prairie, sporting trees only in the flood plain of the Trinity River and its tributaries. The climate is very hot and dry in summer and quite cold in winter. For many species this means there is the chance almost year around to sustain severe damage. For decades the city has been planting oak trees of various varieties, but oak decline is a constant problem. Even the native Texas red oak suffers a myriad of problems when not planted in the most optimum locations. Oak planting will continue into the future because oaks do about as well as other species.

Although the area is not one that is tremendously hospitable to trees, about 2.5 million trees are estimated to cover 288 of Dallas (Fig. 4). Growing space is relatively abundant as well, accounting for 568 of the area. stocking levels. range from 308 in parks to 558 in yard and street locations (Table 5).

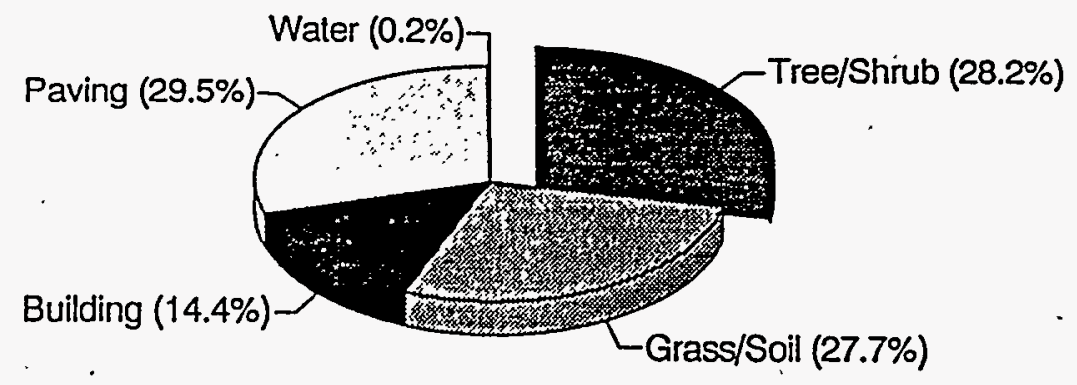

Figure 4. Land cover percentages for Dallas.

Although the Dallas Parks Foundation (DPF), the local non-profit tree planting group, undertakes so-called special projects downtown each year - a few street trees at a high impact intersection or landscaping around various civic auditoriums or in key parks - tree planting is not a downtown priority because the emphasis in downtown Dallas in increasingly on underground and second story linkages between buildings. The street level is becoming devoid of foot traffic.

The primary tree planters in the area are DPF and local developers. According to Phillip Schwolert and Robin Kohler, DPF plants about 5,000 trees per year as yard trees, residential street trees, and parks trees. Citizens are asked to maintain yard and street trees. throughout their lives. Due to budget cuts, the Dallas Parks and Recreation Department is doing almost no planting and barely managing to maintain existing trees. 
Table 5

Initial Estimates of Tree Numbers, Cover, and stocking for Dallas

\begin{tabular}{lrrrrrrrr}
\hline & $\begin{array}{r}\text { Current } \\
\text { Tree }\end{array}$ & $\begin{array}{r}\text { New } \\
\text { Plant- } \\
\text { ings }\end{array}$ & $\begin{array}{r}\text { Curr } \\
\text { Cover } \\
8\end{array}$ & $\begin{array}{r}\text { New } \\
\text { Cover } \\
8\end{array}$ & $\begin{array}{r}\text { Cover } \\
\text { Change } \\
8\end{array}$ & $\begin{array}{r}\text { Curr } \\
\text { stock } \\
8\end{array}$ & $\begin{array}{r}\text { New } \\
\text { stock } \\
8\end{array}$ & $\begin{array}{r}\text { Stock } \\
\text { Change } \\
8\end{array}$ \\
\hline Park & 103,382 & 7,500 & 2.2 & 2.3 & 0.1 & 30.1 & 31.7 & 1.5 \\
Yard . & $1,747,738$ & 6,500 & 23.8 & 23.9 & 0.1 & 55.4 & 55.5 & 0.2 \\
Streets & 405,715 & 14,125 & 0.2 & 0.3 & 0.1 & 56.6 & 57.3 & 0.7 \\
UnImproved & 146,875 & 0 & 2.0 & 2.0 & 0 & 42.6 & 42.6 & 0 \\
Total & $2,403,710$ & 28,125 & 28.2 & 28.4 & 0.2 & 50.4 & 50.9 & 0.5 \\
\hline
\end{tabular}

Local developers have been very cooperative by all accounts about establishing more landscaping and planting more trees than required by landscape ordinances. Indeed many developments have impressive landscaped areas in protected microclimates that are, of course, professionally maintained. A tree preservation ordinance is in the discussion stages.

Approximately 5,625 trees are projected to be planted yearly in Dallas during the next five years, about 1.28 of the current estimated tree population (Table 5 ). Developer Trammel Crow has been donating about 4,000 trees per year for DPF projects. Projected planting costs will reflect a reduced level of donations for DPF trees in school, park, yard, and residential street locations. New plantings will add about 525 acres of tree cover to Dallas, and increase park tree stocking by $1.5 \%$.

As in most cities, tree planting is primarily geared towards beautification, not environmental improvement. However, the potential for air pollution mitigation and cooling energy savings from reforestation is substantial. Both ozone and carbon monoxide exceed federal standards for healthy air in Dallas County. Stormwater runoff control via on-site detention is not required, but regional

retention/detention is practiced. 
Denver is located on a high plains area that is naturally dry and treeless except along watercourses. The city was once heavily forested with American elm. Today Denver has begun a well orchestrated attempt to replace tree canopy cover lost to Dutch Elm disease and to problems caused by ever increasing urbanization. Because of a $\$ 3$ million 1989 tree planting bond issue passed by voters hoping to improve air quality, the city's budget problems are not affecting reforestation efforts as adversely as in many of the cities participating in this study. Tree cover in Denver is 268 and grass/soil cover is 298 (Fig. 5). stocking levels range from 148 in unimproved areas, to 348 in parks and streets, and 58\% in yard locations (Table 6). Hence, there is ample space for these new tree plantings.

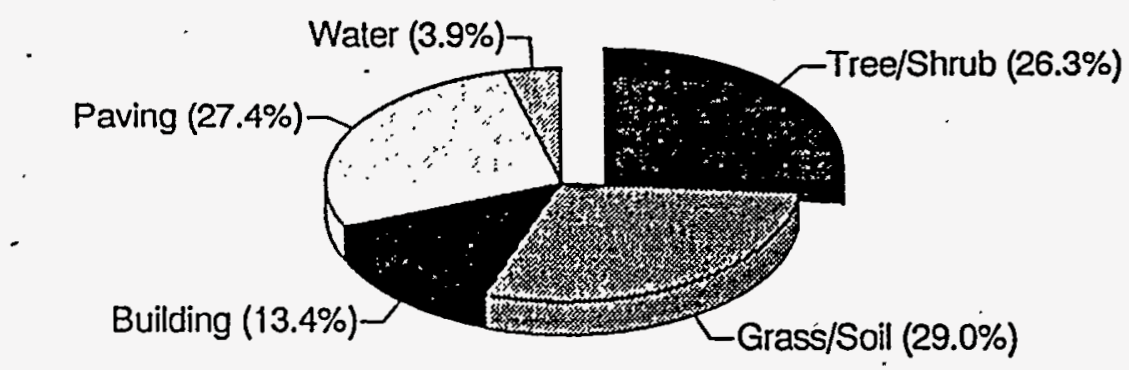

Figure 5. Land cover percentages for Denver.

The Denver Urban Forest is a non-profit group that attempts to act as a clearing house for information about tree planting efforts in the Denver metropolitan area. According to Guenther Vogt, the Denver Parks and Recreation Department will plant 30,000 trees over the next 5 years with the bond monies. These plantings will consist of both park and residential street trees (Table 6 ). In addition to the city's efforts, 10,000 additional trees are being planted over the next few years by volunteers for outdoor Colorado (Voc), a non-profit group led by Dos Chappell that is working to revegetate the banks of the platte River. (Table 6). While this work is currently concentrated outside the Denver city limits, there are miles of barren platte banks and canal banks of various kinds inside the city limits which are typical of the sorts of sites voc targets.

Also at work in the Denver area is one of the most successful utilitysponsored planting programs encountered during the current study. Typicaliy, about 5, 000 trees a year are planted in conjunction with the Public service company's plant a Better Future energy efficiency program. 
Table 6

Initial Estimates of Tree Numbers, Cover, and stocking for Denver

\begin{tabular}{lrrrrrrrr}
\hline & $\begin{array}{r}\text { Current } \\
\text { Tree }\end{array}$ & $\begin{array}{r}\text { New } \\
\text { Plant- } \\
\text { ings }\end{array}$ & $\begin{array}{r}\text { Curr } \\
\text { Cover } \\
\text { Numbers }\end{array}$ & $\begin{array}{r}\text { New } \\
\text { Cover } \\
8\end{array}$ & $\begin{array}{r}\text { Cover } \\
\text { Change } \\
8\end{array}$ & $\begin{array}{r}\text { Curr } \\
\text { stock } \\
8\end{array}$ & $\begin{array}{r}\text { New } \\
\text { stock } \\
8\end{array}$ & $\begin{array}{r}\text { Stock } \\
\text { Change } \\
8\end{array}$ \\
\hline Park & 41,818 & 10,000 & 1.9 & 2.2 & 0.3 & 34.5 & 40.3 & 5.8 \\
Yard & 773,722 & 25,000 & 22.5 & 23.1 & 0.6 & 57.7 & 59.2 & 1.5 \\
Streets & 111,482 & 20,000 & 0.6 & 0.8 & 0.2 & 33.7 & 36.2 & 2.5 \\
UnImproved & 44,718 & 10,000 & 1.3 & 1.5 & 0.2 & 14.3 & 16.5 & 2.2 \\
Total & 971,740 & 65,000 & 26.3 & 27.6 & 1.3 & 47.6 & 49.9 & 2.3 \\
\hline
\end{tabular}

Planting of approximately 65,000 new trees is planned during the next five years in Denver, or about 78 of the nearly 1 million existing trees. We project that these plantings will add 1,300 acres of tree cover, and increase stocking levels in parks by over 58 (Table 6 ).

Water conservation has become a hot topic in the city over the last few years, as controversy rages over whether Denver with its increasing demand for water has any rights to the runoff from the western slopes of the Rocky Mountains. The Denver Water Department makes xeriscape information available and pushes for the use of low-water plants. There appears, however, to be a strong element in the city that prefers to emphasize "an architectural landscape" consisting of lawns accented with overarching shade trees that have performed well in Denver over the years and are not necessarily low-water use. Despite this preference, it is likely that greater consideration will be given to low-water use landscapes in the future.

Another important environmental issue that tree planting in Denver can address is air quality. Inversions during winter trap carbon monoxide from vehicles and particulates (primarily from wood-burning fireplaces), causing periodic exceedances of federal air quality standards. Ozone has the potential to become a more serious health problem during summer if the pace of urbanization increases. Also, the social value of stormwater control is reflected in Denver's Urban Drainage and Flood Control District's investment in numerous retention/detention basins for regional stormwater management. 


\section{Fresno}

Fresno (and neighboring clovis) is a rapidly urbanizing agricultural hub that is currently taking steps to assure that trees are part of the area's future.

Available growing space in Fresno is about 57\%, but most of that is grass/soil cover (408) rather than tree cover (178) (Fig. 6). Street tree stocking (498) is greater than stocking levels for parks (318) and yards (358) (Table 7).

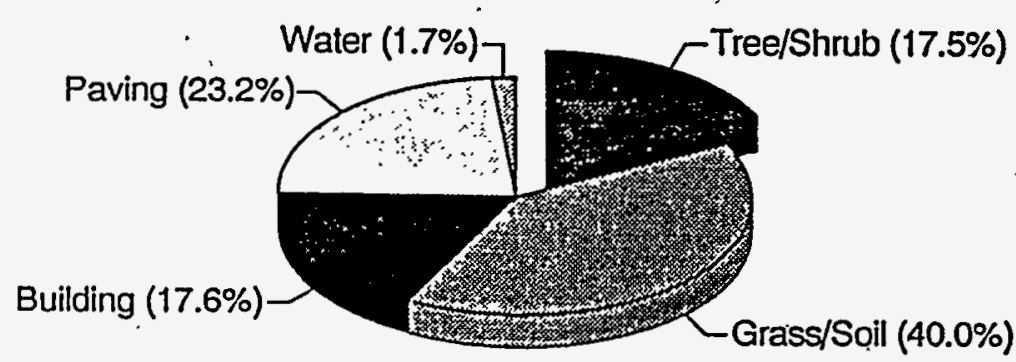

Figure 6. Land cover percentages for Fresno.

Both Fresno and clovis have new-construction tree planting requirements that add thousands of trees per year to the urban forest. In addition, the city of Fresno is mounting an aggressive residential street tree replacement program for established neighborhoods that will replace 18,000 trees over the next 5 years. The vast majority of the reṕlacements will be realized through grants that Rudy castillo and his Parks and Recreation Department has lined up. currently, the city of Fresno manages 130,000 city trees, 89,000 of which are street trees. Because of the local weather - hot and dry - the emphasis, where at all possible, is on wide-spreading shade trees. The various tree planters in the area plan to begin planting a significant number of Valley oak (Quercus lobata), a native riparian tree, once much seen in the area, whose numbers have been greatly reduced with increasing development.

Tree Fresno is the active local non-profit tree planting organization directed by susan stilts. The group has two emphases. The first is the planting of arterial street trees and median plantings in established areas that are treeless. Projects are chosen'based on need and public impact. One highly successful planting saw to the placement of trees along a barren canal running beside a major thoroughfare. Another project, currently in the fund raising stage, is to plant a section of a major arterial near the central core of the city that has never had any trees. The group also tackles an ongoing series of less high profile projects in neighborhoods and schools. 
Table 7

Initial Estimates of Tree Numbers, Cover, and stocking for Fresno

\begin{tabular}{|c|c|c|c|c|c|c|c|c|}
\hline Locations & $\begin{array}{r}\text { Current } \\
\text { Pree } \\
\text { Numbers }\end{array}$ & $\begin{array}{r}\text { New } \\
\text { plant- } \\
\text { ings }\end{array}$ & $\begin{array}{r}\text { Curr } \\
\text { Cover } \\
8\end{array}$ & $\begin{array}{r}\text { New } \\
\text { Cover } \\
8\end{array}$ & $\begin{array}{r}\text { Cover } \\
\text { Change } \\
8\end{array}$ & $\begin{array}{r}\text { Curr } \\
\text { stock } \\
8\end{array}$ & $\begin{array}{r}\text { New } \\
\text { stock } \\
8\end{array}$ & $\begin{array}{r}\text { stock } \\
\text { Change } \\
, 8\end{array}$ \\
\hline Park & 14,442 & 10,000 & 0.9 & 1.3 & 0.4 & 31.0 & 46.1 & 15.1 \\
\hline Yard & 383,568 & 3,750 & 15.3 & 15.4 & 0.1 & 35.3 & 35.6 & 0.3 \\
\hline streets & . 153,736 & 37,500 & 0.4 & 0.9 & 0.5 & 49.3 & 54.1 & 4.8 \\
\hline UnImproved & 22,567 & 0 & 0.9 & 0.9 & 0 & 8.5 & 8.5 & 0.9 \\
\hline Total & 574,313 & 51,250 & 17.5 & 18.6 & 1.1 & 30.4 & 32.3 & 1.9 \\
\hline
\end{tabular}

Pacific Gas and Electric began a shade Tree Program in Fresno last year and is developing a program for new customers who purchase energy-efficient homes. The current program offers a $\$ 5$ coupon as a rebate for planting of approved trees.

We estimate that about 10,250 trees will be planted yearly in Fresno and Clovis, about 98 of Fresno's existing 574,000 trees (Table 7). Our findings indicate that Trees Fresno will be planting an average of 500 and 750 residential and arterial street trees annually, with the remainder planted by the city parks departments and developers. Parks trees are assumed to be planted largely by the parks departments. We estimate that the PG\&E Shade Tree Program will account for 500 yard trees yearly, and developers will plant the remaining 250. These proposed plantings will add about 768 acres of new tree cover, increasing overall tree cover and stocking level by 18 and 28 , respectively. Dramatic increases in stocking of 58 and 158 are estimates for street and park locations.

Because of concerns over the recent California drought, not to mention the ongoing question of government reclamation projects to meet the water demands of local farmers, xeriscape planting is beginning to gain some currency in the Fresno area, However, water is still extremely cheap. The essentially agricultural nature of the area impacts air quality. Airborne particulates are a serious problem due to spraying, crop field burning, and fugitive dust. Ozone and carbon monoxide also exceed health standards at times, largely because Fresno is situated where it gets drifting smog from larger cities to the north and the south. Air quality problems are of great concern and there is good potential for mitigation through tree planting.

Fresno has a regional stormwater retention/detention system that includes a number of basins, each ranging from 10-16 acres in size. An estimated 15-20 new basins will be constructed during the next 5 years. Although new development has dual sewerage, older parts of the city are on a combined sanitary-storm system, which is being gradually converted. 


\section{Los Anqeles}

Los Angeles is a unique city that encompasses at least five distinct climate regions within its boundary. As in most urban centers around the country, city budgets in Los Angeles have gotten progressively tighter in recent years. This trend has had a decided impact on the city's street tree and parks divisions. Both numbers of trees planted and the quality of maintenance have been affected. TreePeople, led by Katie and Andy Lipkis and perhaps the best known non-profit.tree group in the country, has been working for nearly two decades to add what it can to the tree canopy cover in the greater LA area. We found that the amount of available growing space in LA is unexpectedly high (588), with grass/soil cover (358) exceeding tree cover (238) (Fig. 7 ). We estimate that there are nearly 3 million trees in LA. Current stocking in parks is a relatively low 228, compared to stocking levels of about 398 in yards and streets (Table 8 ).

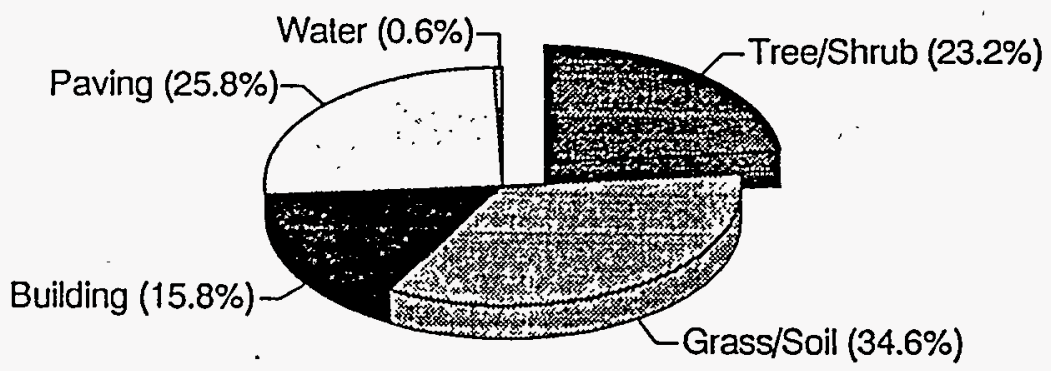

Figure 7. Land cover percentages for Los Angeles.

Based on our interviews, we estimate that about 34,000 trees will be planted yearly during the next 5 years, nearly 68 of the current tree population (Table 8 ). The city plants approximately 2,000 street trees and 1,000 park trees each year. In addition, new construction planting requirements, road alignment planting requirements and other landscape ordinances add thousands of trees per year to the urban forest. TreePeople plants approximately 4,400 street trees per year and 19,000 seedlings in unimproved park and mountain areas. Treepeople has traditionally concentrated heavily on street tree planting because the city's permit system for planting in the public right of way is quite straight forward. These planned plantings will add about 3,000 acres of tree cover, and increase overall stocking by nearly 28 (Table 8 ).

Because of the long drought in the LA area, there is a growing movement calling for native and low-water use planting. The street tree master plan in some cases depends on more water needy trees that have historically done well in an area. An end to this dispute via amendment of the master plan does not seem imminent. 
However, Robert Kennedy, director of the street tree division, states that his priorities are for low water use trees with large canopies, bóth for shade and for greater biomass to help with air quality. Larger tree types with the large canopies are even given preference in smaller planting locations, with root barriers used and other methods employed to mitigate the growing problems associated with large trees in small spaces.

Table 8

Initial Estimates of Tree Numbers, Cover, and stocking for Ios Angeles

\begin{tabular}{lrrrrrrrr}
\hline & $\begin{array}{r}\text { Current } \\
\text { Tree }\end{array}$ & $\begin{array}{r}\text { New } \\
\text { Plant- } \\
\text { ings }\end{array}$ & $\begin{array}{r}\text { Curr } \\
\text { Cover } \\
\text { Numbers }\end{array}$ & $\begin{array}{r}\text { New } \\
\text { Cover }\end{array}$ & $\begin{array}{r}\text { Cover } \\
\text { Change }\end{array}$ & $\begin{array}{r}\text { Curr } \\
\text { stock } \\
8\end{array}$ & $\begin{array}{r}\text { New } \\
\text { stock } \\
8\end{array}$ & $\begin{array}{r}\text { Stock } \\
\text { Change } \\
8\end{array}$ \\
\hline Park & 26,533 & 5,000 & 0.4 & 0.5 & 0.1 & 22.2 & 25.2 & 2.9 \\
Yard & $1,243,294$ & 10,000 & 12.0 & 12.1 & 0.1 & 38.3 & 38.6 & 0.3 \\
Streets & 576,576 & 60,000 & 0.6 & 0.8 & 0.2 & 39.0 & 40.6 & 1.6 \\
UnImprvd & $1,056,796$ & 95,000 & 10.2 & 10.8 & 0.6 & 44.0 & 46.7 & 2.8 \\
Total & $2,903,199$ & 170,000 & 23.2 & 24.2 & 1.0 & 40.1 & 41.8 & 1.7 \\
\hline
\end{tabular}

Interestingly, air quality managers with the south coast Air Quality

Management District project that hydrocarbons from trees will be enough decades into the future, that they alone will keep the IA basin from meeting clean air standards. This'is a problem that is currently being studied and lists of trees with low hydrocarbon emission rates have been developed.

TreePeople is beginning to implement Ios Angeles Department of Water and Power's new program to help. people plant yard trees to reduce emissions of carbon dioxide through increased energy efficiency. Southern California Edison is considering establishing its own tree planting program for energy conservation, which could add $3-6$ million trees to the region.

Because IA is built-out it.has little control over stormwater it receives from upstream basins. Runoff flows through concrete channels into the ocean without treatment. Urbanization upstream has resulted in larger flows and increased probability of flooding. New stormwater control measures for the IA River are being studied by the Army Corps of Engineers and others. 
Miami

Dade County; the southernmost Florida county which contains Miami and 26 other incorporated municipalities, has been extremely hard hit by strained budgets over the last decade or so. In addition to the money problems that plague most American urban areas, Dade County and Miami have had to deal with an influx of immigrants

- that have nearly overwhelmed many city services. As a consequence, Miami and other local municipalities, which at one time had flourishing tree planting operations, have moved trees far down on their list of priorities. A few upscale Dade County cities, such as Coral Gables and North Miami Beach, are the exceptions and still have active. tree programs.

Miami has a relatively low amount of available growing space (40\%), but over half of it is in tree cover (218) (Fig. 8). We estimate that there are nearly a quarter million trees in Miami, shading about 9,000 acres (Table 9). Current stocking levels range from 50-558 in parks, yards, and streets, but there were no trees on unimproved lands in our sample.

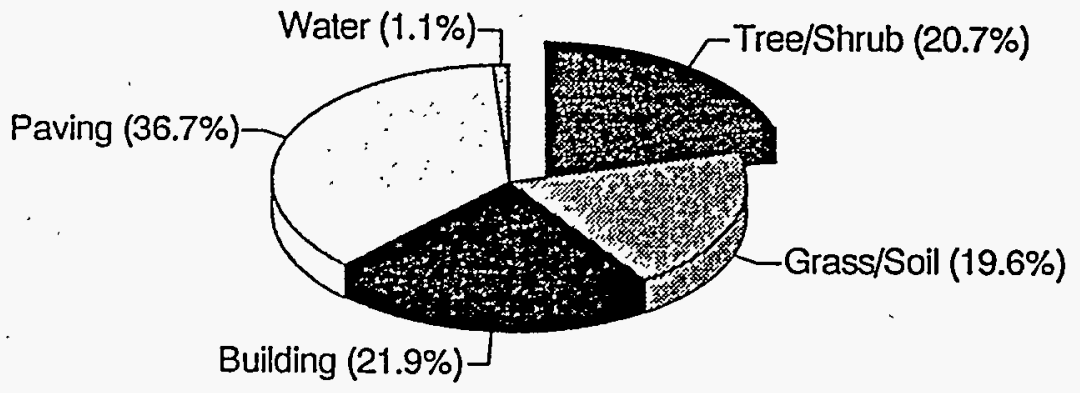

Figure 8. Land cover percentages for Miami.

According to Brian Harmes, director of the street tree division of the Miami Department of Public Works, cuts in funding and personnel have left him unable to mount a tree planting program at all any more, despite the fact that downtown canopy cover has shrunk to less than 2\%. Maintenance on existing trees is by hazard and emergency calls only. Currently the first priority of this department as well as for various other municipalities and for unincorporated Dade county is tree preservation based on a tough ordinance. The county ordinance (cities within the county must have ordinances as tough or tougher) stipulates that trees over 18" caliper on public or private property cannot be cut down without a permit. The ordinance carries fines for noncompliance and requirements to replant smaller trees for large trees removed. Other parts of the landscape code, continue being debated and revised. For example, new commercial construction landscape requirements stipulate that a percentage of all developed acreage be given over to landscape plantings, but there is no requirement about maintenance or replacing lost plant materials and many newly installed landscapes have been being allowed to die, according to city officials. 
Table 9

Initial Estimates of Tree Numbers, Cover, and stocking for Miami

\begin{tabular}{lrrrrrrrr}
\hline & $\begin{array}{r}\text { Current } \\
\text { Tree }\end{array}$ & $\begin{array}{r}\text { New } \\
\text { Plant- } \\
\text { ings }\end{array}$ & $\begin{array}{r}\text { Curr } \\
\text { Cover } \\
8\end{array}$ & $\begin{array}{r}\text { New } \\
\text { Cover } \\
8\end{array}$ & $\begin{array}{r}\text { Cover } \\
\text { Change } \\
8\end{array}$ & $\begin{array}{r}\text { Curr } \\
\text { stock } \\
8\end{array}$ & $\begin{array}{r}\text { New } \\
\text { Stock } \\
8\end{array}$ & $\begin{array}{r}\text { Stock } \\
\text { Change } \\
8\end{array}$ \\
\hline Park & 9,939 & 125,000 & 2.0 & 19.6 & 17.6 & 54.0 & 529.8 & 475.8 \\
Yard & 142,889 & 275,000 & 18.4 & 46.7 & 28.3 & 52.7 & 133.9 & 81.2 \\
Streets & 85,726 & 25,000 & 0.3 & 1.4 & 1.1 & 51.2 & 57.2 & 6.0 \\
UnImprvd & 0 & 75,000 & 0 & 6.8 & 6.8 & 0 & 3,364 & 3,364 \\
Total & 238,554 & 500,000 & 20.7 & 74.5 & 53.8 & 51.4 & 184.8 & 133.4 \\
\hline
\end{tabular}

Trees for Dade is a fledgling non-profit tree planting group led by Dr. John Parker that wants to fill the gap in tree planting in the area. The emphasis of the group is on tree planting for energy efficiency on residential properties and school properties. Restoration of native plantings on unimproved lands also will receive special attention. The group's goal is to plant 500,000 trees over the next five years, roughly twice the number of existing trees (see projected plantings in Table 9). School property plantings have a special priority in this program because a recently passed bond election will see the county constructing perhaps more new schools over the next several years than any county in the country. Not only are there no landscape budgets for these new schools, but many existing schools have gone without landscaping except for turf. School districts in Dade are the largest landowners in the county next to government.

Trees for Dade plans to plant primarily native and drought resistant trees. There is an emerging water crisis in Dade County, which is just beginning to face up to the environmental damage done to the Everglades by, among other things, the channelization and diversion of natural waterways for manmade development projects. Energy conservation is a natural enough emphasis to emerge in an area known for its year-around warm climate. Also global warming is a stated concern of program. organizers. If the proposed plantings occur, the amount of tree cover will more than double (Table 9). Based on our limited sample, there may not be enough growing space in parks and unimproved lands within Miami to accomodate all the trees proposed for these locations.

Dade county is a non-attainment area for ozone, and excessive concentrations of carbon monoxide is an infrequent problem. Miami requires on-site exfiltration, which effectively controls flooding due to the region's highly permeable soils. In these systems, surface runoff is routed to trenches filled with porous rock or perforated pipe, which results in rapid percolation into the soil. 


\section{Minneapolis}

All the municipal tree planting done within the Minneapolis city limits is done by the Forestry Division of the Parks and Recreation Board. The innovative nonprofit group Twin Cities Tree Trust is kept from planting in the city because of conflicts with the union. Minneapolis has a rich history of tree planting and greenspace management, as evidenced by its extensive tree cover. However, our Iimited sampling for Minneapolis (see Table 2 ) does not bear this out (98 tree cover, Fig. 9). Although we sampled many. street trees and found stocking to be very high there (678), relatively few trees were sampled in the overall land cover analysis (Table 10). We will increase the sample to rectify this problem.

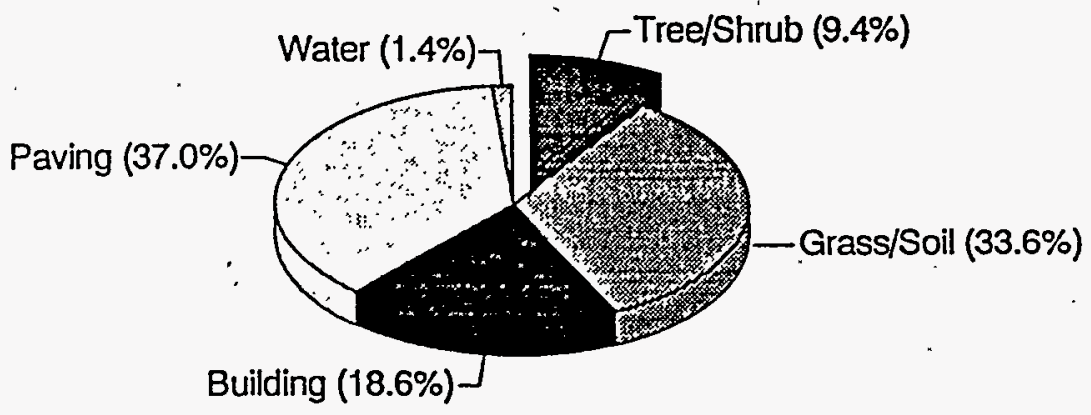

Figure 9. Land cover percentages for Minneapolis.

Although forestry director David Devoto and his crews have recently suffered a 508 cut in funding and have seen their yearly plantings slashed from a high of 20,000 trees in the $1970 \mathrm{~s}$ to $3,000-5,000$ trees (see Table 10), they still have one of the most professional and well run departments in the country. A premium is placed on good maintenance and the pruning cycle has been kept at 5 years. The department has the wherewithal to reallocate the funds it does have, for example, in drought years from planting new trees, that will not get the best start, to arranging emergency watering programs for existing trees. The city has a beautiful standing urban forest that numbers 170,000 municipal trees. The proposed plantings are estimated to add about 325 acres of tree cover to Minneapolis in 30 years (Table 10).

In the late 1970s, due to losses from Dutch elm disease (DED), the department in cooperation with neighborhood.groups from around the city, established as its ongoing priority, the reforestation of neighborhood street tree plantings strips, locally called tree boulevards. While there are ongoing losses every year to DED the numbers are fewer and fewer. In fact, because of effective treatment measures, 508 of the city's American elm stock is still growing. A catastrophic drought in 
1988 had a severe impact on the city's trees that is continuing to be felt, as stricken trees fail to regain vigor or fall prey to insects. However, the forestry division has been very active in presenting tree care clinics for citizens during these years of drought and residual drought impact, just as they were during the DED onslaught.

Table 10

Initial Estimates of Tree Numbers, Cover, and stocking for Minneapolis

\begin{tabular}{lrrrrrrrr}
\hline & $\begin{array}{r}\text { Current } \\
\text { Tree }\end{array}$ & $\begin{array}{r}\text { New } \\
\text { Plant- } \\
\text { ings }\end{array}$ & $\begin{array}{r}\text { Curr } \\
\text { Cover } \\
\text { Numbers }\end{array}$ & $\begin{array}{r}\text { New } \\
\text { Cover } \\
8\end{array}$ & $\begin{array}{r}\text { Cover } \\
\text { Change } \\
8\end{array}$ & $\begin{array}{r}\text { Curr } \\
\text { stock } \\
8\end{array}$ & $\begin{array}{r}\text { New } \\
\text { stock } \\
8\end{array}$ & $\begin{array}{r}\text { Stock } \\
\text { Change } \\
8\end{array}$ \\
\hline Park & 23,449 & 3,750 & 2.8 & 3.1 & 0.3 & 29.2 & 32.4 & 3.3 \\
Yard & 86,385 & 0 & 6.6 & 6.6 & 0 & 20.0 & 20.0 & 0 \\
Streets & 142,560 & 21,250 & 0 & 0.5 & 0.5 & 67.4 & 71.5 & 4.1 \\
UnImproved & 0 & 0 & 0 & 0 & 0 & 0 & 0 & 0 \\
Total & 252,394 & 25,000 & 9.4 & 10.3 & 0.9 & 21.9 & 23.9 & 2.0 \\
\hline
\end{tabular}

Minneapolis, as is typical of most metropolitan areas of its size, has air quality problems that it is working to solve. Winter inversions create occasional periods when carbon monoxide concentrations exceed health standards. Particulates can be a problem near several stationary industrial sources. Two large retention/detention basins normally function as parks but handle storm sewer overflow during large rainfall events. The sewerage system is nearly entirely separated, with very little stormwater treatment at present. Treatment options are being studied. Because the high water use season is so brief, water conservation is not a serious concern of the water utility." State legislation regarding global climate change has resulted in research to determine the cost-effectiveness of tree planting for energy conservation, but utility-sponsored programs are not in place. 


\section{Portland}

Portland is a beautiful mid-sized city that is obviously well treed, both downtown and throughout many of its neighborhoods. Portland has a relatively large amount of growing space (658), and two-thirds of this area is in tree cover $(428$ overall) (Fig. 10). Park locations in our sample were nearly fully stocked, and stocking levels in other areas were about 508 (Table 11). This abundance of urban forest cover is due in no small part to a hugely successful municipal planting program $(130,000$ trees planted) stretching back to 1975. But budget problems have caused the city's urban forestry projects to be cut back by more than 758 over the last few years, including both planting and maintenance (the latter is of particular concern). Alex Wynstra, the city's urban forester, hopes to make up some of the short fail by coming up with grant monies and Friends of Trees (FOT), the local nonprofit tree planting group organized by Richard Seidman, also is trying to pick up some of the slack. Trees are being planted along streets by developers because of the current landscape ordinance, and if passed, a new ordinance that applies to home construction'will increase residential street tree planting.

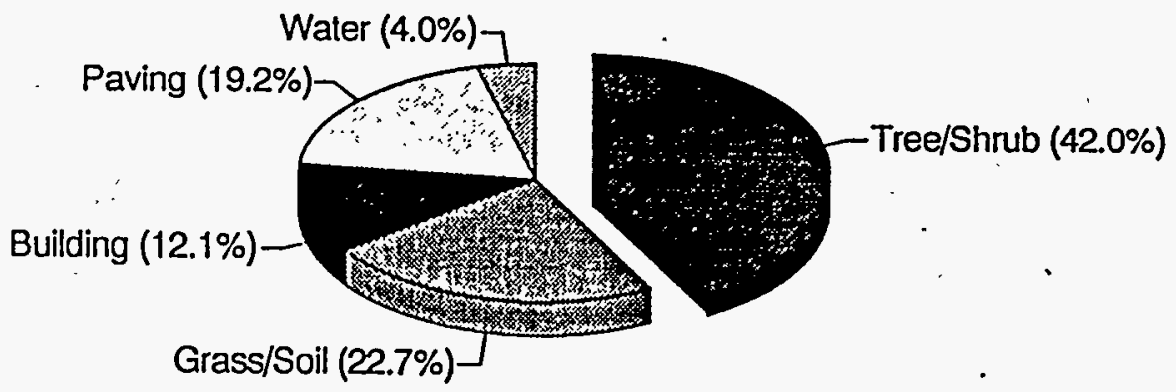

Figure 10. Land cover percentages for Portland.

FOT concentrates its efforts on neighborhood street tree planting projects where homeowners take lifetime responsibility for trees. The group is particularly interested in the idea of playing a role in neighborhood revitalization through tree planting. FOT also is involved in seedling plantings of unimproved park areas within the city. We project that about 8,800 trees will be planted annually in Portland, with FOT responsible for most plantings along residential streets and in. unimproved lands (Table 11). These planned plantings represent nearly 48 of the estimated 1.2 million trees currently in Portland. In addition to adding over 700 acres of urban forest cover, the plantings are projected to icrease stocking in streets and unimproved areas by 28 and 58 , respectively. 
Table 11

Initial Estimates of Tree Numbers, Cover, and stocking for Portland

\begin{tabular}{lrrrrrrrr}
\hline & $\begin{array}{r}\text { Current } \\
\text { Tree }\end{array}$ & $\begin{array}{r}\text { New } \\
\text { Plant- } \\
\text { ings }\end{array}$ & $\begin{array}{r}\text { Curr } \\
\text { Cover } \\
8\end{array}$ & $\begin{array}{r}\text { New } \\
\text { Cover } \\
8\end{array}$ & $\begin{array}{r}\text { Cover } \\
\text { Change } \\
8\end{array}$ & $\begin{array}{r}\text { Curr } \\
\text { Stock } \\
8\end{array}$ & $\begin{array}{r}\text { New } \\
\text { Stock } \\
8\end{array}$ & $\begin{array}{r}\text { Stock } \\
\text { Change } \\
8\end{array}$ \\
\hline Park & 404,586 & 1,250 & 20.8 & 20.8 & 0 & 94.5 & 94.7 & 0.2 \\
Yard & 492,381 & 5,000 & 16.2 & 16.3 & 0.1 & 49.9 & 50.3 & 0.4 \\
Streets & 162,594 & 19,250 & 0.3 & 0.5 & 0.2 & 46.9 & 49.2 & 2.3 \\
UnImproved & 142,854 & 18,500 & 4.7 & 5.1 & 0.4 & 51.7 & 56.3 & 4.7 \\
Total & $1,202,415$ & 44,000 & 42.0 & 42.8 & 0.8 & 64.9 & 66.2 & 1.3 \\
\hline
\end{tabular}

Although water would seem to be no problem in the Portland area, the Portland Water Bureau is starting to develop a long term plan for water conservation, hoping to instill in its customers the concept of proper stewardship of water resources. Their objective is to reduce the summertime peak demand, which is largely due to. landscape water use during drought periods.

Portland General Electric will launch a major campaign to plant trees with new energy-efficient homes (we will assume 500 yard trees per year in the benefit-cost analysis). The goal in Portland is to locate "solar-friendly" trees to minimize winter shade yet still provide summer cooling.

Air quality in Multinomah county is generally good, although carbon monoxide concentrations have exceeded EPA standards. Regional detention basins are located along rivers and streams to delay flows from the region's long, low intensity storm events. Stormwater runoff is separately sewered and untreated flows are released. into rivers and streams. 
Rock Valley is a tiny town (population 3,000) in the extreme northwestern corner of Iowa. It is most interesting in terms of this study for its participation in the Iowa Public service Electric/Midwest Gas energy efficiency program. For the program, every one of the 1,000 residences in Rock valley will be especially metered and monitored carefully over a period of years so that specifics about electric and gas use can be learned. Part of the energy efficiency program is a discount/rebate program ( 508 total off the regular price of a tree) sponsored by the Global ReLeaf affiliate Trees Forever, which encourages residents to plant up to two trees on their properties. To receive rebates, citizens must stipulate that trees were planted in energy efficient locations. Meanwhile, the energy use monitoring will offer a clear picture of how plantings effect energy use over the years.

Due to a relatively small sample size, the accuracy of land cover data for Rock valley is suspect. Tree cover was found to be only 78 , and no trees were sampled in park or street locations (Fig. 11, Table 12). The initial findings suggest that there is a large amount of available growing space that is mostiy covered with grass/soil. Although this trend could be expected for a small city in the prarie, more intensive sampling will be undertaken to examine the reliability of these estimates.

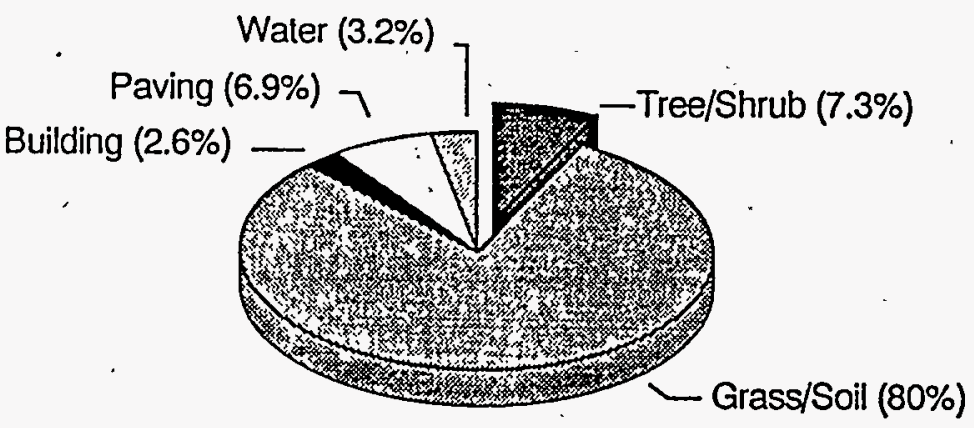

Figure 11. Land cover percentages for Rock Valley, Iowa.

Rock Valley has lost approximately 5,000 elms to Dutch elm disease in the last decade. These elms were located in yards and along street right-of-ways. In the first year of the energy efficiency project, citizens have been planting yard trees about 3 to 1 over street trees. But because the town has such a long tradition of street trees, local nursery owner and tree advocate Jim Vander velde predicts that almost all of the vacant street tree locations will eventually be replanted. This will have to be done by citizens because the city has no real budget for sustained 
tree planting. We project a planting rate of 400 trees a year for the next five years (Table 12).

Table 12

Initial Estimates of Tree Numbers, Cover, and stocking for Rock Valley

\begin{tabular}{lrrrrrrrr}
\hline & $\begin{array}{r}\text { Current } \\
\text { Tree }\end{array}$ & $\begin{array}{r}\text { New } \\
\text { Plant- } \\
\text { ings }\end{array}$ & $\begin{array}{r}\text { Curr } \\
\text { Cover } \\
\text { Numbers }\end{array}$ & $\begin{array}{r}\text { New } \\
\text { Cover } \\
8\end{array}$ & $\begin{array}{r}\text { Cover } \\
\text { Change } \\
8\end{array}$ & $\begin{array}{r}\text { Curr } \\
\text { stock } \\
8\end{array}$ & $\begin{array}{r}\text { New } \\
\text { stock } \\
8\end{array}$ & $\begin{array}{r}\text { Stock } \\
\text { Change } \\
8\end{array}$ \\
\hline Park & 0 & 0 & 0 & 0 & 0 & 0 & 0 & 0 \\
Yard & 659 & 1,500 & 2.9 & 8.4 & 5.5 & 7.5 & 21.3 & 13.8 \\
Streets & 1,126 & 500 & 0 & 0.8 & 0.8 & 41 & 48.3 & 7.3 \\
UnImproved & 971 & 0 & 4.4 & 4.4 & 0 & 9.4 & 9.4 & 0 \\
Total & 2,756 & 2,000 & 7.3 & 13.6 & 6.3 & 8.4 & 15.6 & 7.2 \\
\hline
\end{tabular}

Trees Forever, directed by shannon Ramsey, is a statewide organization (an organ of the Iowa Natural Heritage Foundation) and is helping to implement energy efficient planting programs working with several different power companies in the state. The state legislature has mandated that all power companies operating within the state must implement energy conservation plans. This move came as part of a package to reduce carbon dioxide emissions from fossil fuel burning power plants. While air quality is a concern in the larger urban centers of the state, it is not an issue of local concern in Rock Valley. storm and sanitary sewerage systems are separate, with untreated runoff discharged into rivers. stormwater retention and detention basins are not used in Rock valley: 
Tucson is a midsized Southwestern city that prides itself on its use of drought tolerant plantings to reverse a trend towards urban desertification. predictably, the movement to plant trees in the city has vocal adherents and equaliy vocal detractors. The city, which worked very hard to become an oasis in the desert from its founding through about the second World war, importing all manner of exotic shrubs and trees, has in recent decades embraced its arid lands heritage, priding itself for being much more a desert city than water gulping Phoenix two hours north on the freeway.

This turnaround was due in no small part to the fact that Tucson's water rates climbed steeply in the $1970 \mathrm{~s}$. Unfortunately, many residents responded to higher water prices by simply allowing their landscapes to die. There has been a documented decrease in vegetation cover within the city beginning with the ready availability of air conditioning and accelerating through recent worries about the proper uses of increasingly expensive water. Approximately 600,000 trees cover only 148 of the city at present, while bare soil, rock, and grass cover 448 of the area (Fig. 12). There is plenty of room for new plantings, especially in parks and yards, which have stocking levels of about 258 (Table 13).

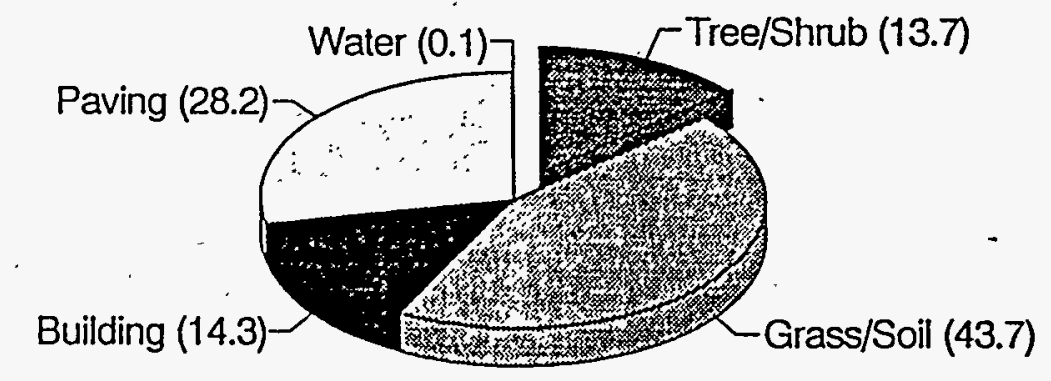

Figure 12. Land cover percentages for Tucson.

The city has no ongoing tradition of street tree planting or an urban forestry program. However, landscaping has increasingly been a budgeted part of major street improvements. The lack of trees in residential areas undoubtedly has to do with the fact that preferred desert trees tend to be of medium height and spreading. They don't cover much area per stem, and can interfere with both pedestrian and vehicular traffic when placed in narrow public right-of-ways. Desert trees seldom achieve the over-arching canopy that most people prize in street trees. The city's Parks and Recreation Department, which maintains a well-treed system of parks and golf courses, has lobbied against street trees because of concerns over insufficient budgets for maintenance and liability issues. However, Trees for Tucson/Global 
Releaf, working with a generally sympathetic city council, in 1989 launched a campaign to plant 500,000 desert-adapted trees. This number was lowered two years later as city budget problems somewhat reduced official support and citizens continued to express concern over the water needs of thousands of trees. TFT/GR is looking at more strategic targeting for future plantings, at places such as bus stops where the need for shade trees is undeniable. Previous plantings with the Tucson Urban League were designed to conserve energy for cooling in low income neighborhoods. Educating the public as to the benefits of tree planting for energy savings continues to be emphasized.

Table 13

Initial Estimates of Tree Numbers, Cover, and stocking for Tucson

\begin{tabular}{lrrrrrrrr}
\hline & $\begin{array}{r}\text { Current } \\
\text { Tree }\end{array}$ & $\begin{array}{r}\text { New } \\
\text { Plant- } \\
\text { ings }\end{array}$ & $\begin{array}{r}\text { Curr } \\
\text { Cover } \\
8\end{array}$ & $\begin{array}{r}\text { New } \\
\text { Cover } \\
\text { Locations }\end{array}$ & $\begin{array}{r}\text { Cover } \\
\text { Change } \\
8\end{array}$ & $\begin{array}{r}\text { Curr } \\
\text { stock } \\
8\end{array}$ & $\begin{array}{r}\text { New } \\
\text { Stock } \\
8\end{array}$ & $\begin{array}{r}\text { Stock } \\
\text { Change } \\
8\end{array}$ \\
\hline Park & 11,226 & 25,000 & 0.5 & 1.3 & 0.8 & 19.2 & 49.2 & 30.0 \\
Yard & 297,945 & 25,000 & 8.5 & 9.1 & 0.6 & 24.0 & 25.6 & 1.6 \\
Streets & 135,399 & 35,000 & 0.1 & 0.4 & 0.3 & 45.5 & 50.2 & 4.7 \\
UnImprvd & 161,261 & 15,000 & 4.6 & 4.9 & 0.3 & 24.7 & 26.3 & 1.6 \\
Total & 605,831 & 100,000 & 13.7 & 15.7 & 2.0 & 23.9 & 27.3 & 3.4 \\
\hline
\end{tabular}

Based on our interviews, we estimate that 100,000 trees (178 of the current tree population) will be planted during the next five years in Tucson. These plantings will increase tree cover by $28(2,000$ acres $)$ and overall stocking by 3.48 . Park tree stocking is projected to increase from 20-508 (Table 13).

Air quality and stormwater control are important issues that tree planting can address in Tucson. Concentrations of paticulates and carbon monoxide have exceeded health standards. In nearby phoenix, summertime ozone is also a problem. Tucson has regulations that require on-site detention-retention, as well as a several regional basins. Stormwater is not directed into pipes, but rather flows in streets and channels, then into rivers. 
Washington, D.C.

The city of Washington, D.C. planted its first street tree in 1816. Today, we estimate that nearly 200,000 trees shade about 98 of the city. Although Washington, D.C. is more densely developed than many cities, there is still plenty of room for more trees. Over 808 of the available growing space is currently in grass/soil cover, and the overall tree stocking level is only 198 (Fig. 13, Table 14). Street tree stocking $(36 \%)$ is greater than stocking levels at other locations.

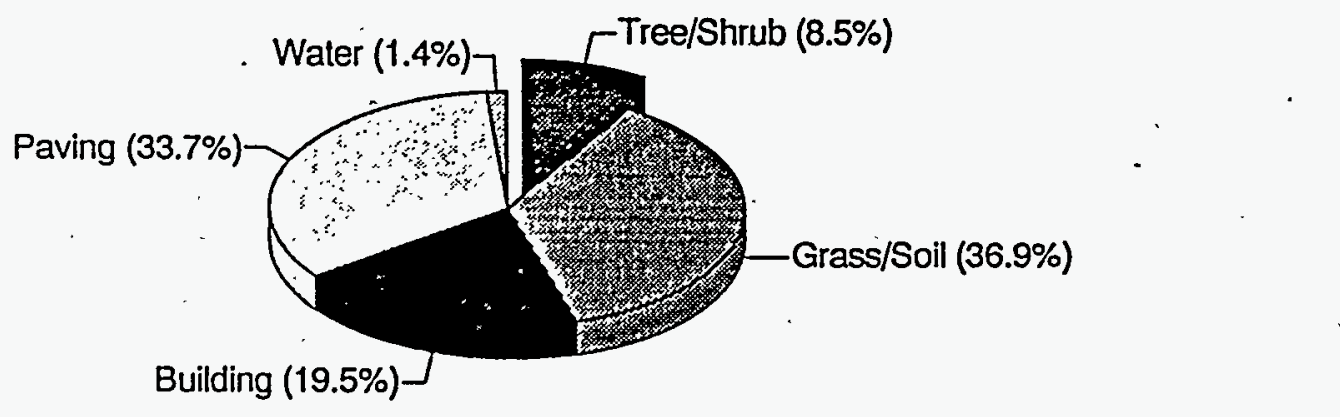

Figure 13. Land cover percentages for Washington, D.C.

The tree maintenance division of the Department of Public Works, run by Hans Johannsen, has faired better than such departments in most urban centers through the budget cutting of recent years. The department still has a budget hovering at $\$ 3$ miliion annualiy. It plants 3,000 trees per year, removes about 3,000 trees per year and keeps to a pruning cycle of 5 years. It began the move to computerized inventories in 1973. The fruits of its efforts are easy to see. standing at almost any intersection in the city, one can look in all four directions and see tree lined streets. Trees are always planted at $40 \mathrm{ft}$ intervals. Citizens have historically considered themselves in a partnership with the city to raise the street trees. They are asked to water in times of drought and report problems to the tree maintenance division.

This is not to say that everything is going perfectly for the department. The hard truth is that despite Johannsen's efforts, the city falls behind farther each year with tree replacements. There are currently 8,000 empty spaces for trees, plus 2,000 existing stumps to be removed to make way for new planting and 2,000 standing dead trees. 
Table 14

Initial Estimates of Tree Numbers, Cover, and stocking for Washington, D.C.

\begin{tabular}{lrrrrrrrr}
\hline & $\begin{array}{r}\text { Current } \\
\text { Tree }\end{array}$ & $\begin{array}{r}\text { New } \\
\text { Plant- } \\
\text { ings }\end{array}$ & $\begin{array}{r}\text { Curr } \\
\text { Cover } \\
8\end{array}$ & $\begin{array}{r}\text { New } \\
\text { Cover } \\
8\end{array}$ & $\begin{array}{r}\text { Cover } \\
\text { Change } \\
8\end{array}$ & $\begin{array}{r}\text { Curr } \\
\text { Stock } \\
8\end{array}$ & $\begin{array}{r}\text { New } \\
\text { Stock } \\
8\end{array}$ & $\begin{array}{r}\text { Stock } \\
\text { Change } \\
8\end{array}$ \\
\hline Park & 15,685 & 6,250 & 1.6 & 2.0 & 0.4 & 28.6 & 36.6 & 8.0 \\
Yard & 96,438 & 0 & 6.3 & 6.3 & 0 & 17.7 & 17.7 & 0 \\
Streets & 78,806 & 25,000 & 0.2 & 0.7 & 0.5 & 32.3 & 36.3 & 4.0 \\
UnImproved & 6,136 & 5,000 & 0.4 & 0.6 & 0.2 & 16.0 & 25.2 & 9.2 \\
Total & 197,065 & 36,250 & 8.5 & 9.7 & 1.2 & 18.7 & 21.4 & 2.7 \\
\hline
\end{tabular}

Trees for the City is a newly formed non-profit tree planting group headed by John Nelson. It has ambitious plans to help make up this shortfall in tree plantings by adding 2,000 street trees per year, in addition to park and seedling plantings along deforested water courses. Certainly, Washington, D.C. has a tradition of supporting public tree plantings - Johannsen states that public pressure is the primary reason his budgets have remained at the levels they have. All concerned are quite hopeful that Trees for the City will indeed be planting significant numbers of trees over the next five years. We project that about 7,250 trees will be planted annually in Washington, D.C. during the next 5 years, or about 188 of the current tree population (Table 14). Trees for the City plantings are expected to account for all of the park and school trees, as well as 2,000 of the street trees. The Metropolitan Washington Council of Governments anticipates planting 1,000 seedlings a year as part of its reforestation effort.' The new plantings are projected to add over 500 acres of tree cover, and increase park and street tree stocking levels by 88 and 48 , respectively (Table 14).

Washington is not a city that's particularly worried about its water supplies. New trees require little supplemental watering after the first few weeks or monthis depending on the weather. Large shade trees are the preferred species because of the city's warm, muggy summer weather. still, officials plantings trees tend to state their motivations more in aesthetic and historical terms rather than in terms of energy savings.

Summertime ozone levels occasionally reach unhealthful levels in Washington, D.C. Because the city is so densely developed there is little room for retention/detention basins. Stormwater runoff is primarily controlled using oversized pipes and rooftop detention. 
Appendix A

Tree Data for Modeling Benefits and Costs of

Planned Tree plantings in Demonstration Cities

Table $A-1$

Tree Data for Atlanta

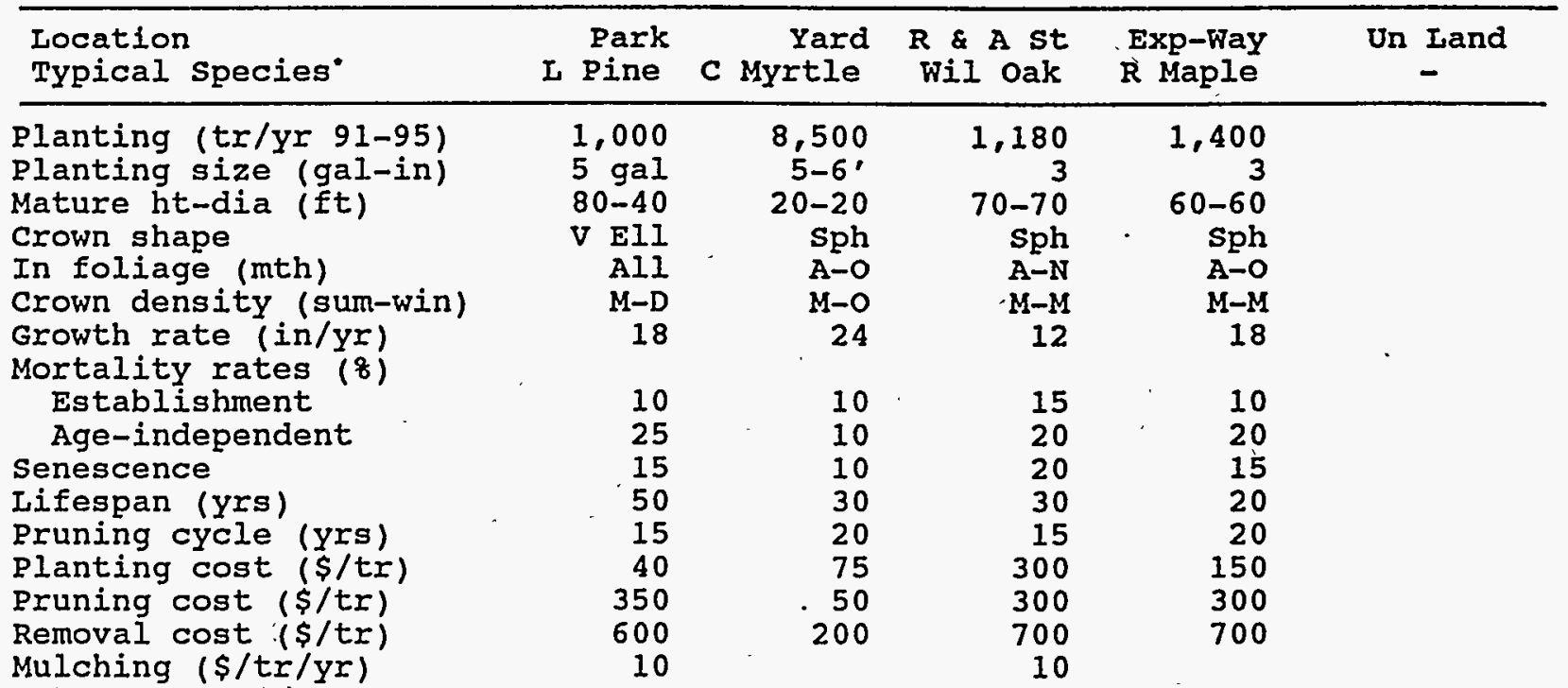

other cost $(\$ /$ tr $)$

- Typical species are: loblolly pine, crape myrtle, willow oak, red maple.

Sources of information: Ms. Marcia Bansley, Trees Atlanta

Mr. Jay Lowery, City Forester

Mr. Ed Laws, Georgia Department of Transporation

Mr. Ed Macie, USDA Forest Service 
Table A-2

Tree Data for Boston

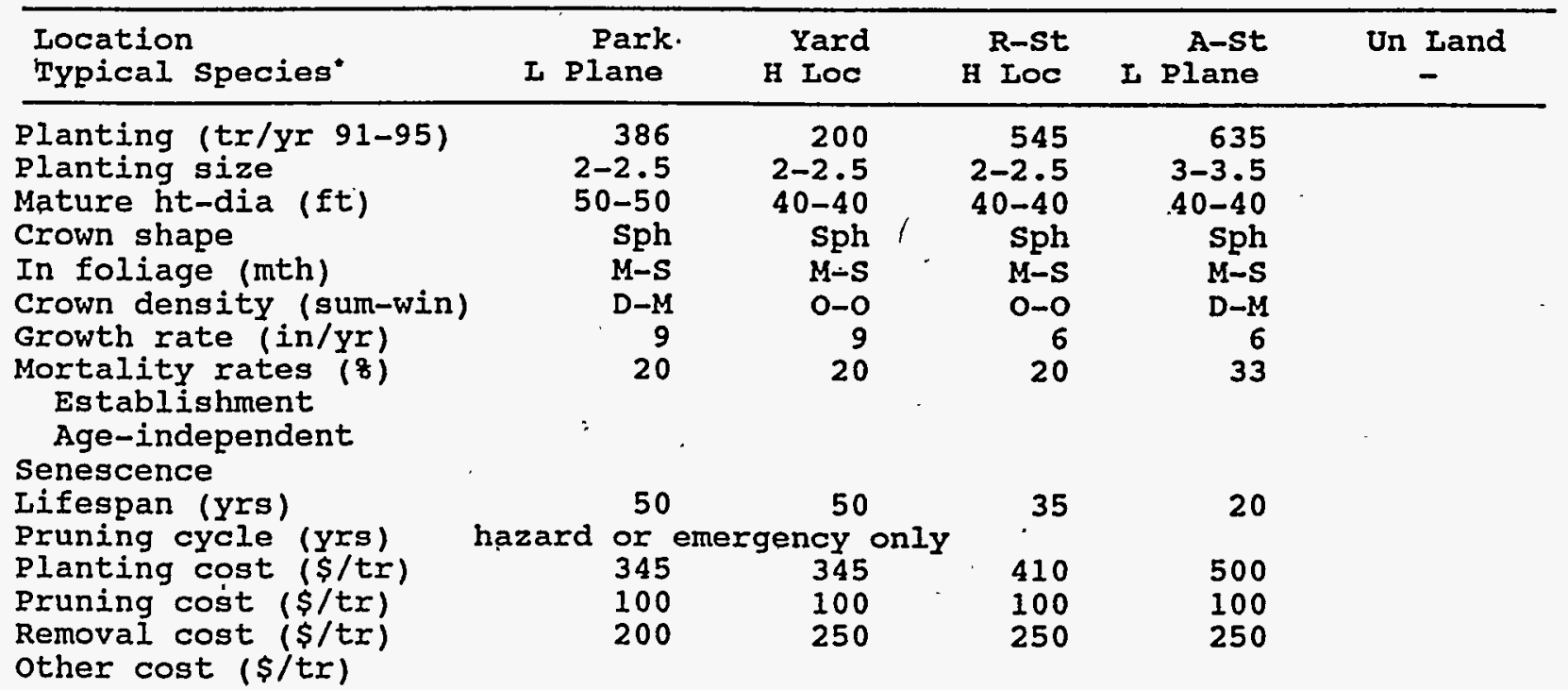

- Typical species are: honey locust, London plane tree.

Sources of information: Mr. Brian Gilbert, Boston Tree Warden Mr. Peter Jackson, Metropolitan District Commission

Ms. Jennifer Rooks, Massachusetts Releaf 
Table A-3

Tree Data for Dallas

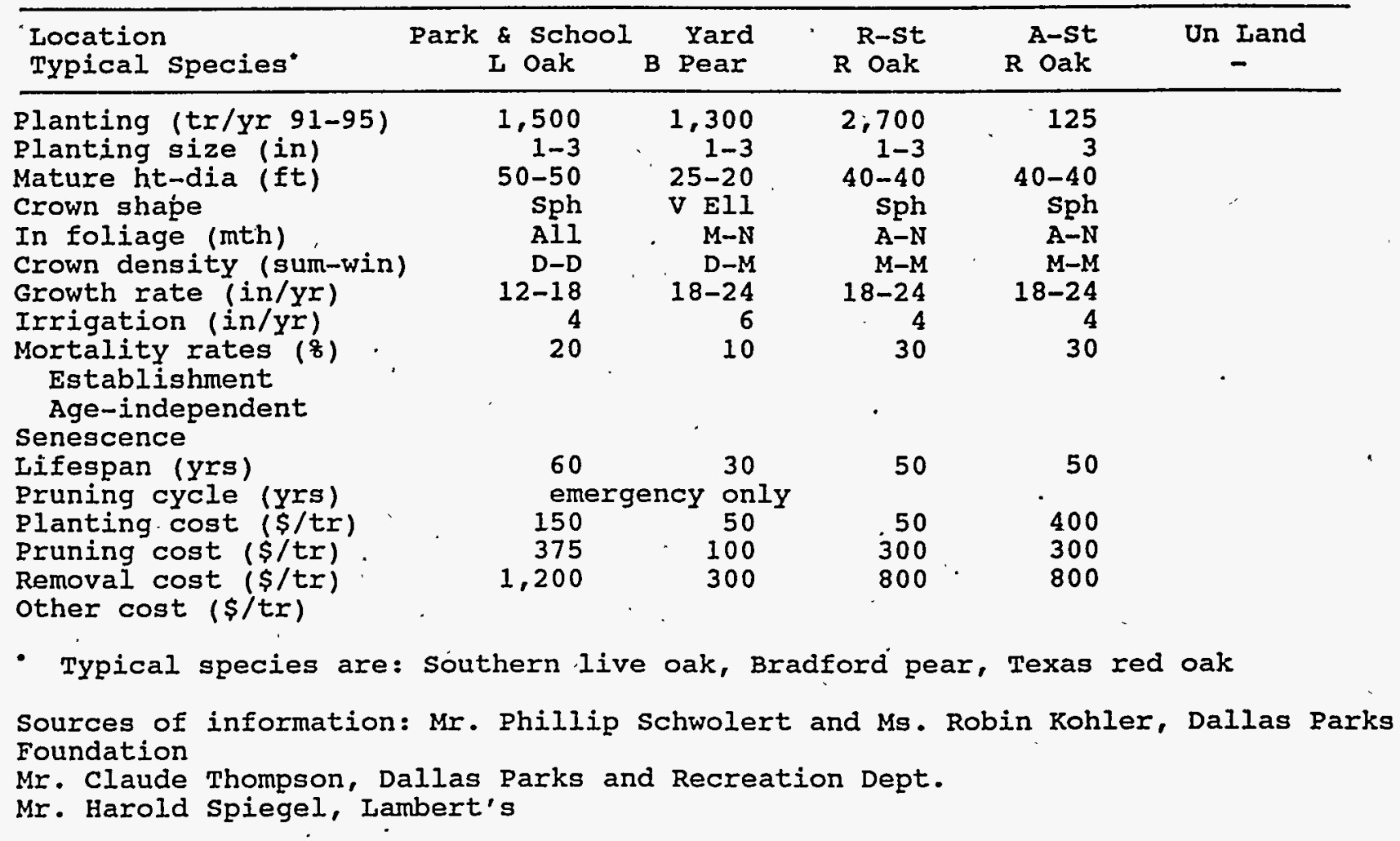


Table A-4

Tree Data for Denver

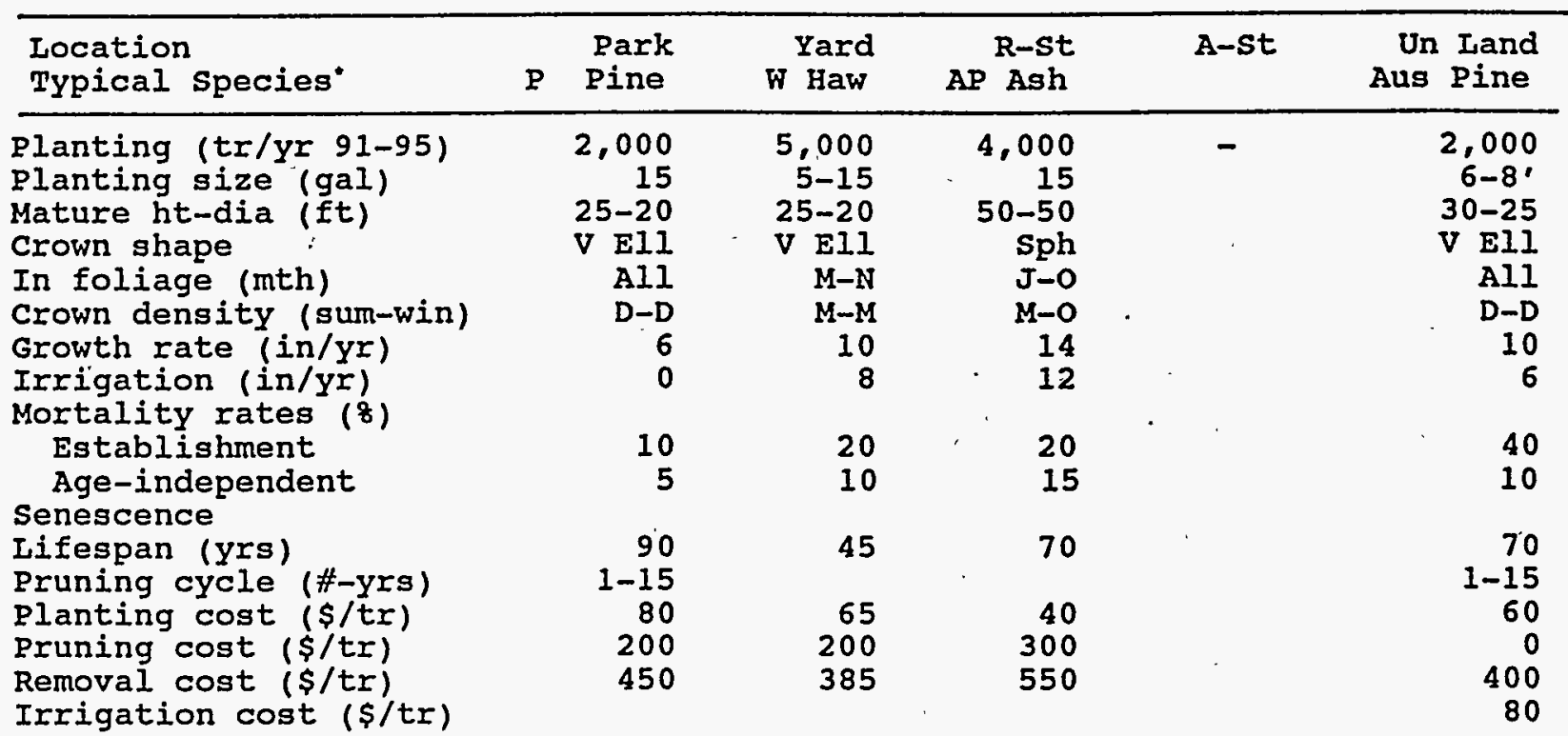

- Typical species are: pinon pine, Washington hawthorn, autumn purple white ash, Austrian pine.

Sources of information: Mr. Guenther Vogt, Deputy Manager-Parks, Denver Parks and Recreation Dept.

Mr. Dos Chappell, Executive Director, Volunteers for outdoor Colorado

Mr. Dan Danbaum, Public Service Corporation

Mr. Bruce Wilhelm, Wilhelm Tree and Lawn Care 
Table A-5

Tree Data for Fresno

\begin{tabular}{|c|c|c|c|c|c|}
\hline $\begin{array}{l}\text { Location } \\
\text { Typical species" }\end{array}$ & $\begin{array}{r}\text { Park } \\
\text { Camphor }\end{array}$ & $\begin{array}{l}\text { Yard } \\
\text { G Rain }\end{array}$ & $\begin{array}{c}\text { R-St } \\
\mathrm{v} \text { oak }\end{array}$ & $\begin{array}{c}\text { A-st } \\
\text { oak }\end{array}$ & $\begin{array}{c}\text { Un I and } \\
-\end{array}$ \\
\hline $\begin{array}{l}\text { Planting (tr/yr 91-95) } \\
\text { Planting size } \\
\text { Mature ht-dia (ft) } \\
\text { Crown shape } \\
\text { In foliage (mth) } \\
\text { Crown density (gum-win) } \\
\text { Growth rate (in/yr) } \\
\text { Irrigation (in/Yr) } \\
\text { Mortality rates (8) } \\
\text { Establishment } \\
\text { Age-independent } \\
\text { Senescence } \\
\text { Lifespan (yrs) } \\
\text { Pruning cycle (yrs) } \\
\text { Planting cost (\$/tr) } \\
\text { Pruning cost ( } / \text { tr) } \\
\text { Removal cost ( } / \text { tr) } \\
\text { other cost (\$/tr) } \\
\text { - Typical species are: } \\
\text { Sources of information: } \\
\text { Mr. Tom Dhillon, Park S } \\
\text { Mr. Rudy Castilio, Dire } \\
\text { Mr. Dave Hallam, Arboris } \\
\text { Mr. Alan Goto, Pacific }\end{array}$ & $\begin{array}{r}60 \\
8 \\
87 \\
300 \\
800 \\
\\
\\
\text { camphor, g } \\
\text { Ms. Susan } \\
\text { pervisor, } \\
\text { tor, Fresn } \\
\text { t, Fresno } \\
\text {;as \& Elect }\end{array}$ & $\begin{array}{r}750 \\
15 \\
40-40 \\
\mathrm{Sph} \\
\mathrm{M}-0 \\
\mathrm{D}-\mathrm{M} \\
24 \\
12 \\
25 \\
10 \\
40 \\
82 \\
300 \\
350 \\
\\
\text { ldenrain } \\
\text { tilts, T? } \\
\text { :ity of } \mathrm{C} \\
\text { Parks ar } \\
\text { arks and } \\
\text { :ic }\end{array}$ & $\begin{array}{r}5,500 \\
5-15 \\
70-70 \\
\text { Sph } \\
\mathrm{M}-\mathrm{N} \\
\mathrm{M}-\mathrm{M} \\
48 \\
10 \\
\\
5 \\
20 \\
\\
80 \\
8 \\
87 \\
400 \\
1,000 \\
\\
\\
\text { ee, vall } \\
\text { Fresno } \\
\text { Fis } \\
\text { Recreati } \\
\text { cereation }\end{array}$ & $\begin{array}{l}80 \\
8 \\
150 \\
400 \\
1,000 \\
\\
y \text { oak } \\
\\
\\
\\
\text { Dept. } \\
\text { Dept. }\end{array}$ & " \\
\hline
\end{tabular}


Table A-6

Tree Data for Los Angeles

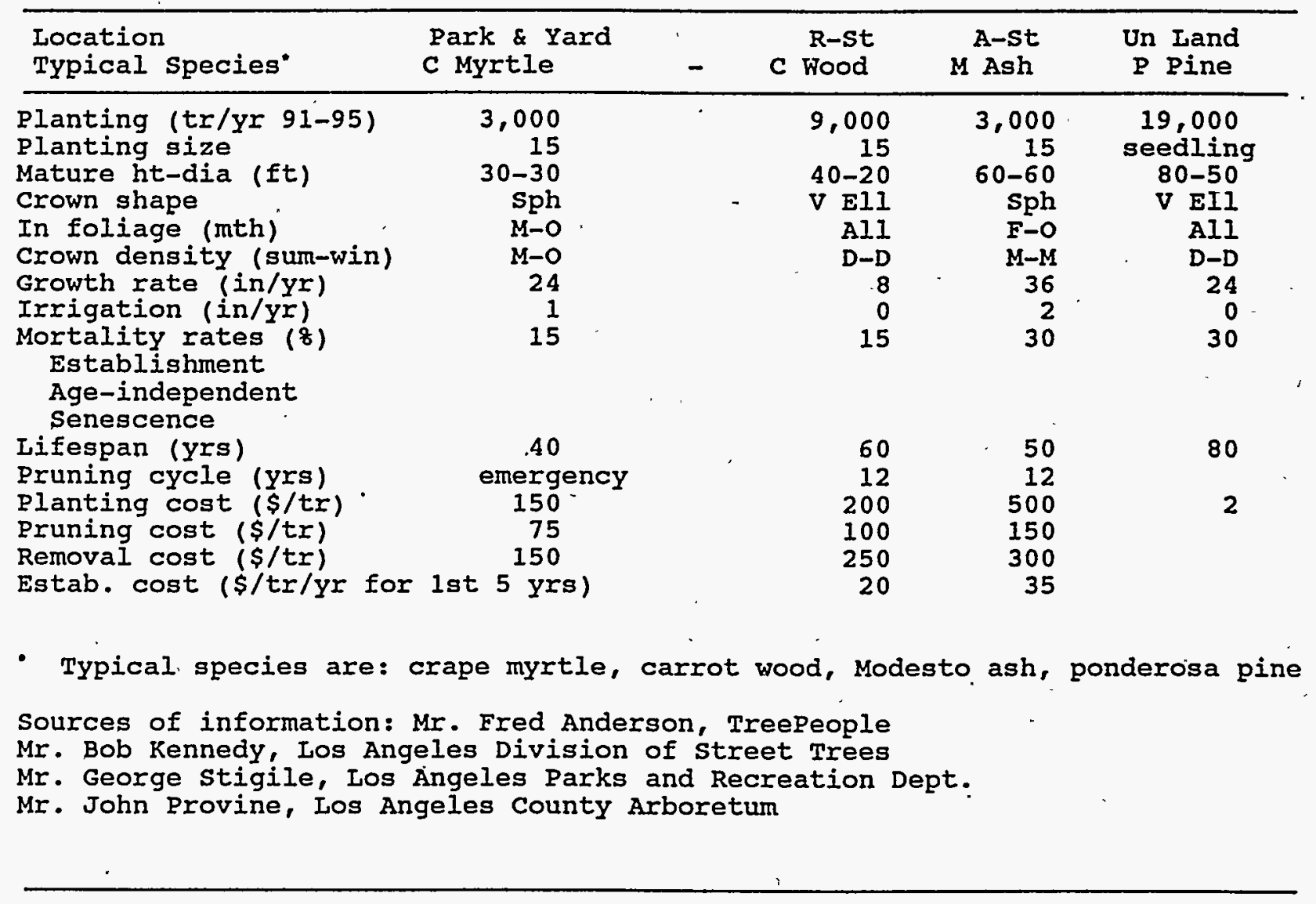


Table A-7

Tree Data for Miami

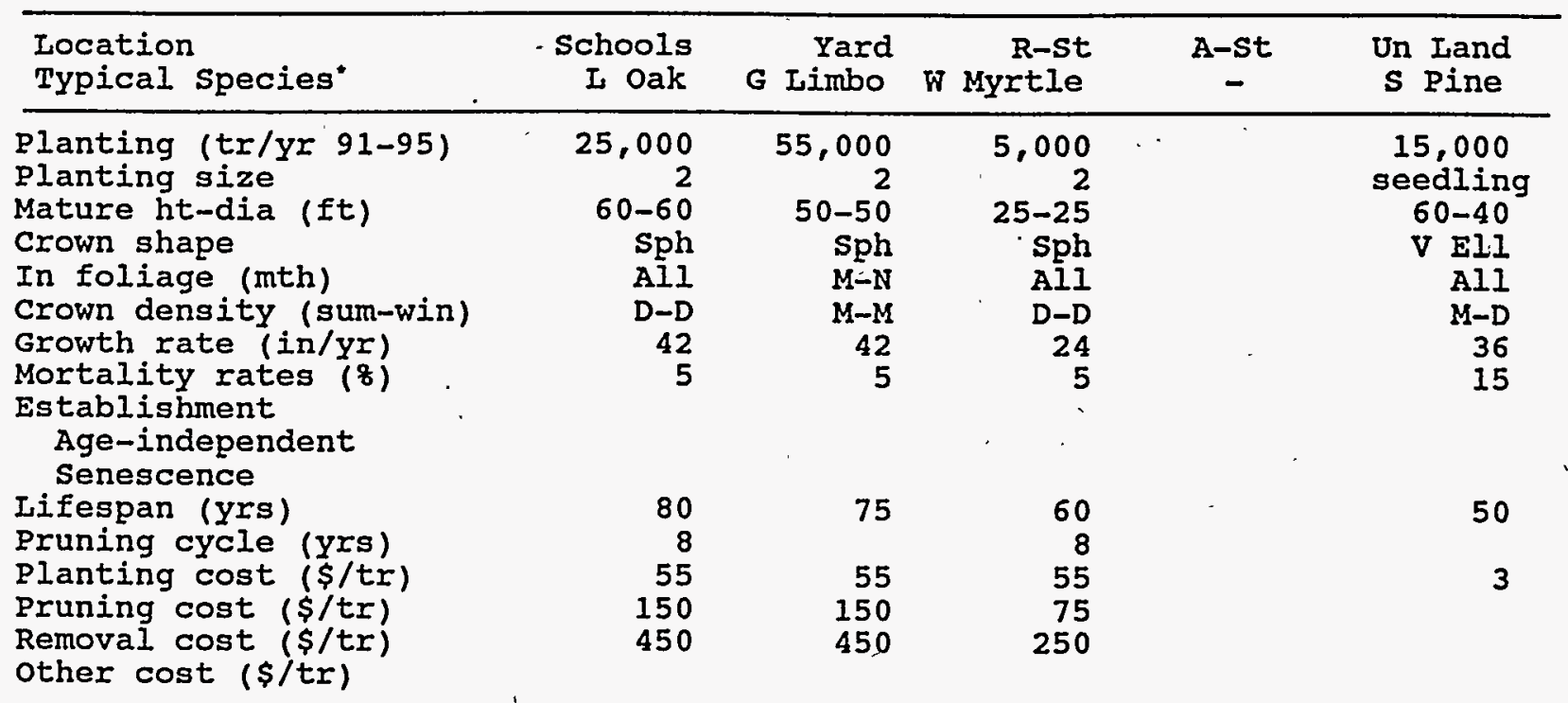

- Typical species are: Southern live oak, gumbo-limbo, wax myrtle, slash pine Sources of information: Dr. John Parker, Trees for Dade

Mr. George Shrader, Arborist

Mr. Jon Glenn, Dade County Urban Forester

Mr. Bryan Harms, Dept. of Public Works, City of Miami 
Table A-8

Tree Data for Minneapolis

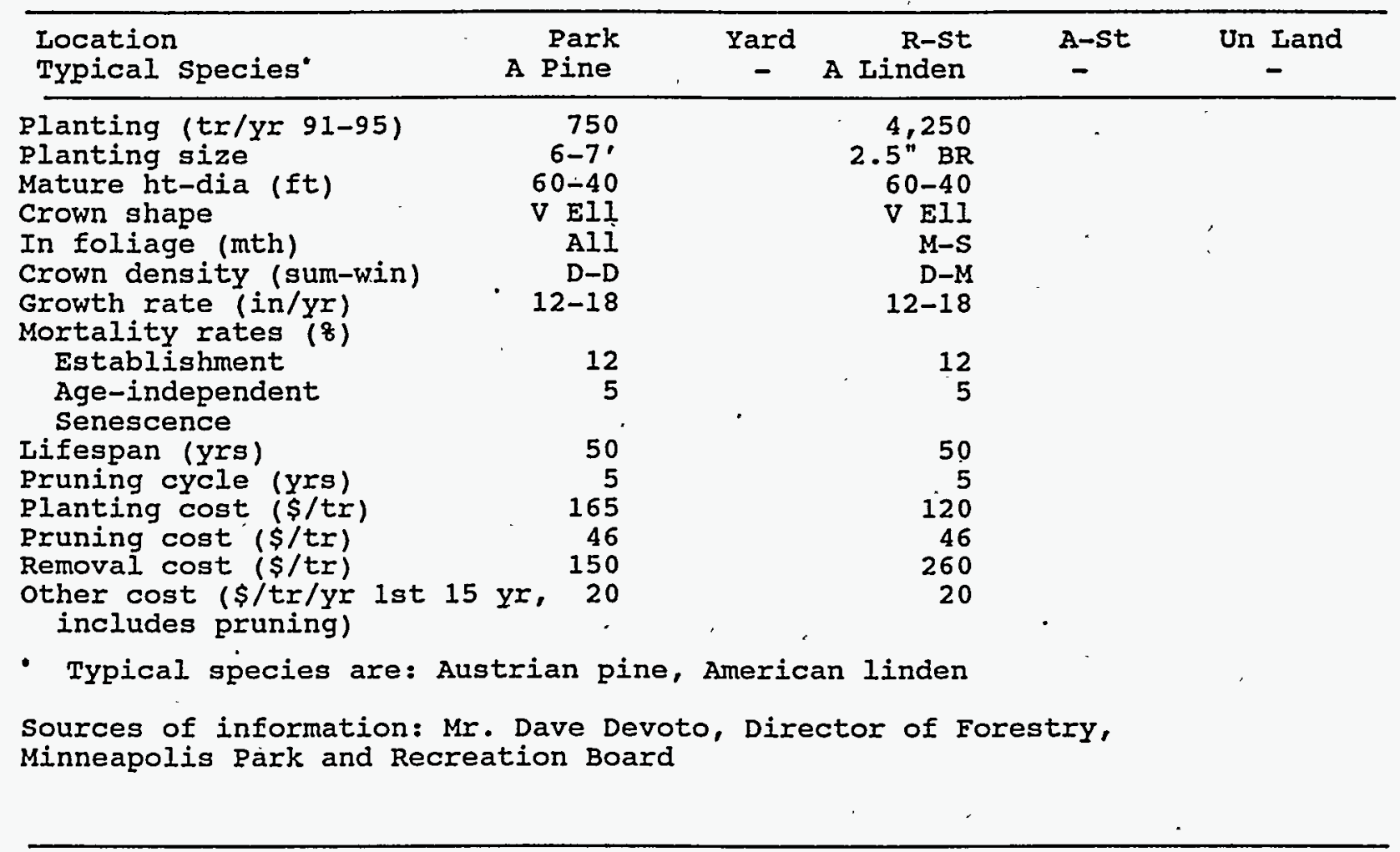


Table A-9

Tree Data for Portland

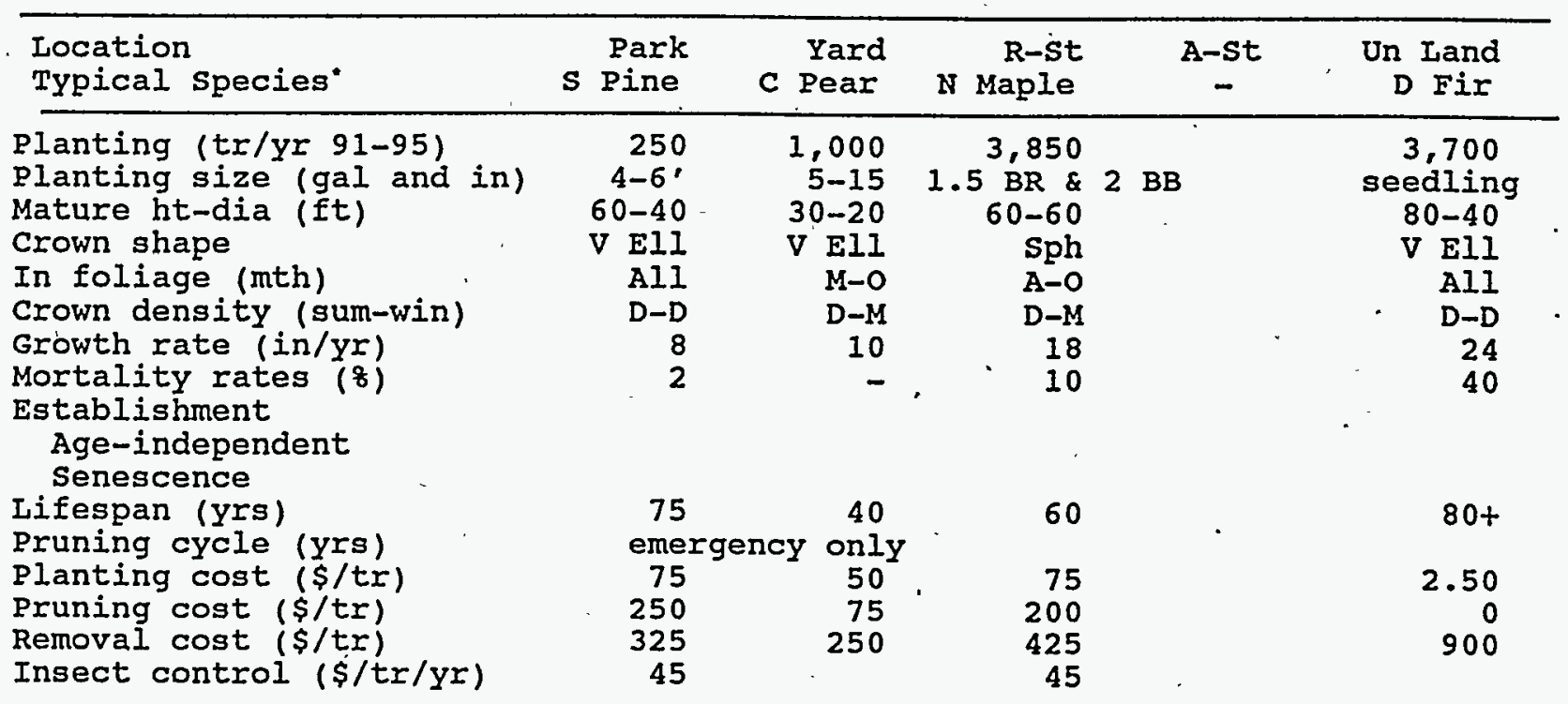

- Typical species are: Scots pine, Chanticleer pear, Norway maple, Douglas fir Sources of information: Mr. Richard Seidman, Friends of Trees Mr. Alex Wynstra, Portland City Forestry Dept.

Mr. Dave Johnson, Portland General Electric Co. 
Table A-10

Tree Data for Rock Valley

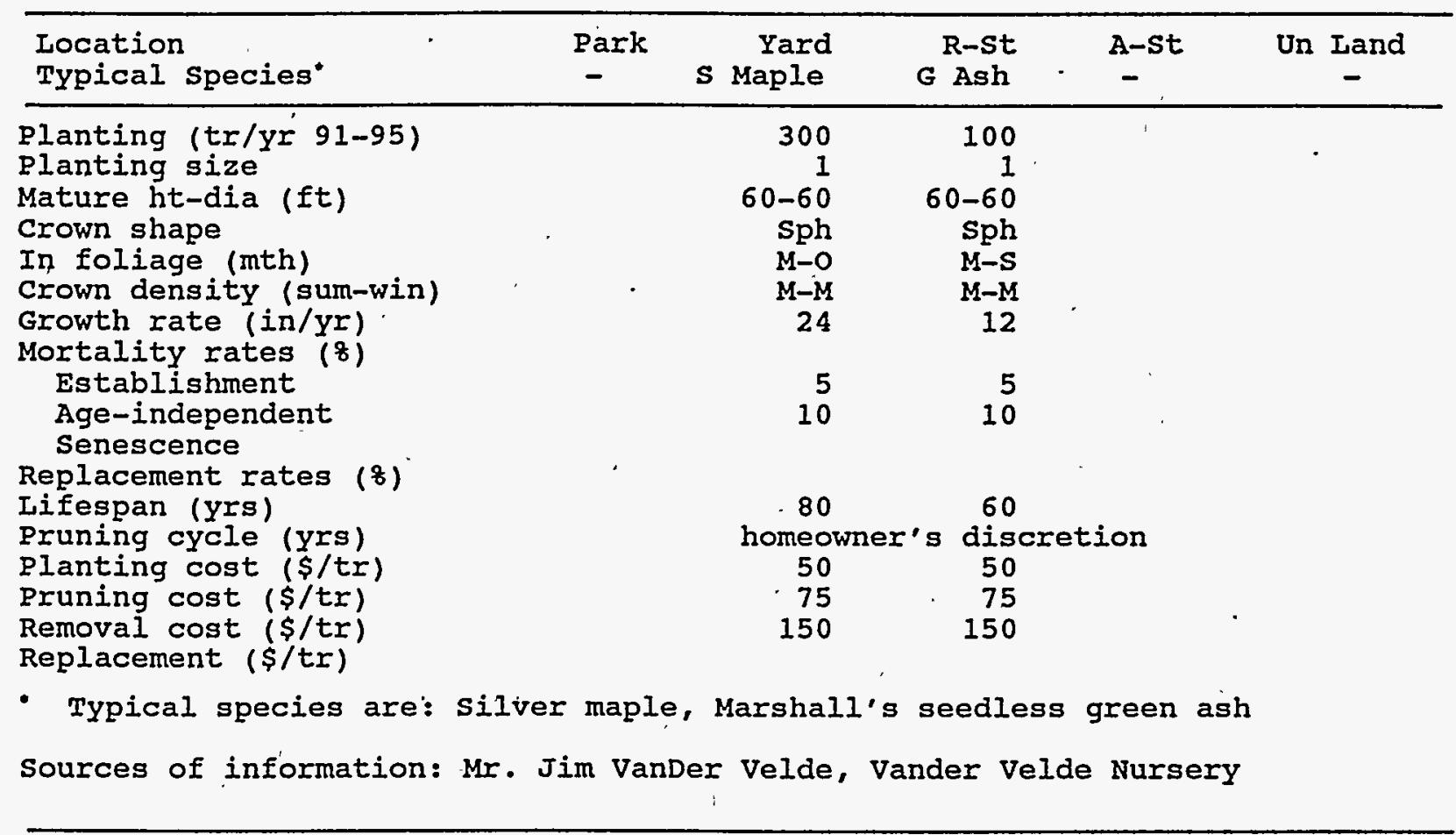


Table A-11

Tree Data for Tucson

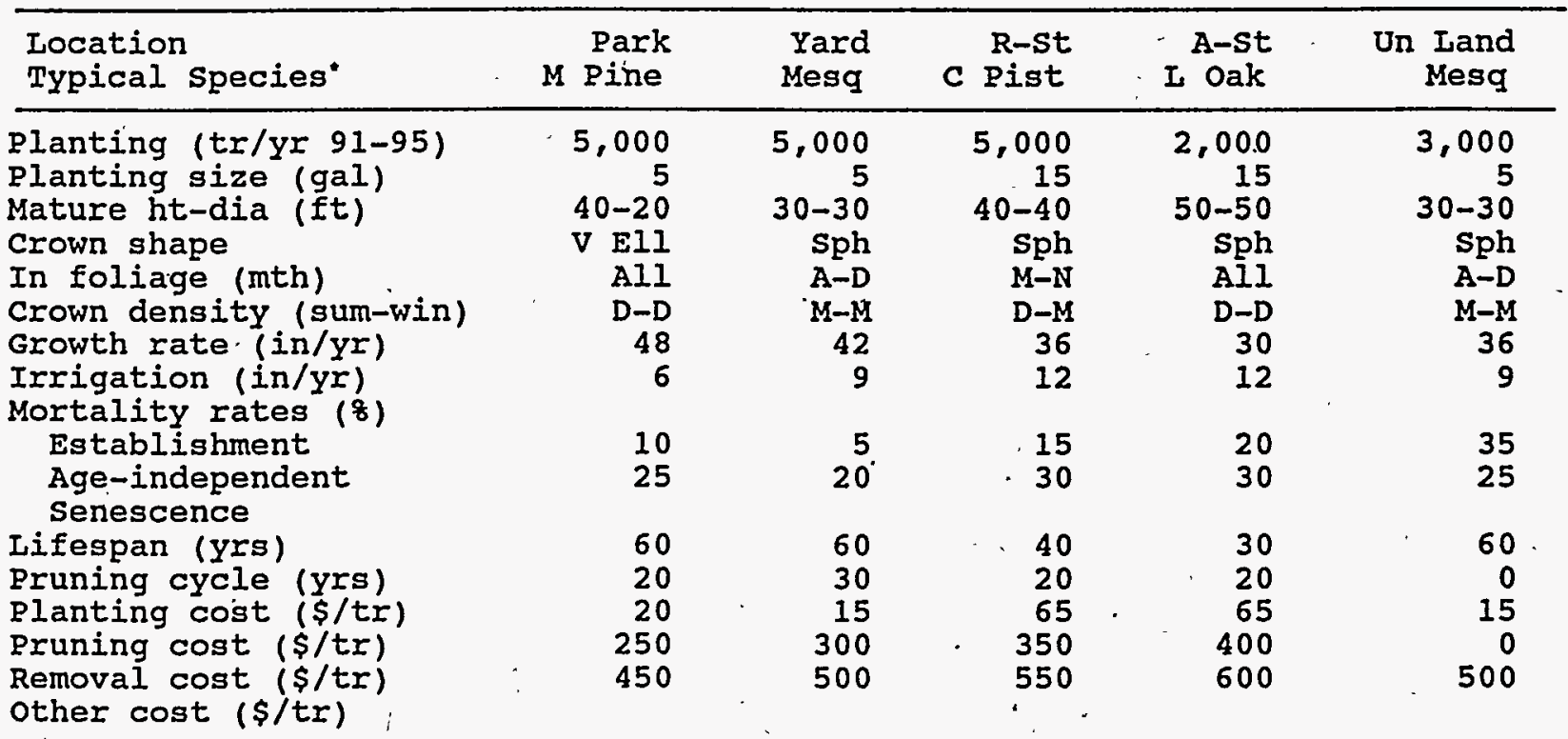

- Typical species are: mondell pine, velvet mesquite, chinese pistache, southern live oak.

Sources of information: Ms. Joan Lionetti, Tucson Clean \& Beautiful

Ms. Laura Nichols, Deputy Director, Parks and Recreation Dept.

Mr. Joe Hatch, Transportation Engineering Dept. . 
Table A-12

Tree Data for Washington, D.C.

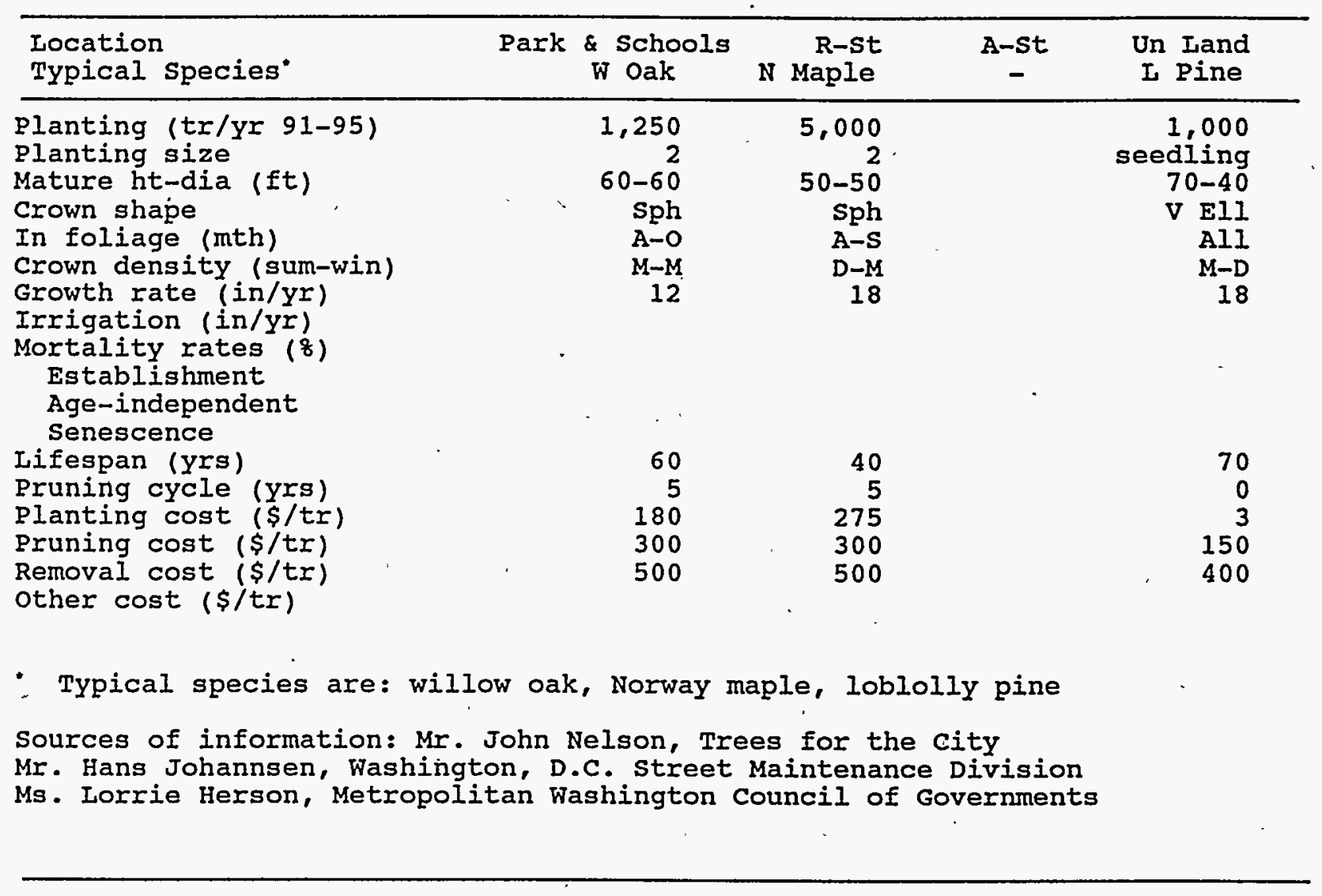




\section{Appendix B}

Utility Data for Demonstration Cities

Table B-1,

Electric Utility Data

\begin{tabular}{|c|c|c|c|c|c|c|c|c|c|c|c|c|}
\hline city & Res & $\begin{array}{l}\text { s Rate } \\
\$ / \mathrm{kWh}\end{array}$ & $\begin{array}{c}8 \\
\text { WAC }\end{array}$ & $\begin{array}{l}\mathrm{AC} \\
\operatorname{Reg}\end{array}$ & $\begin{array}{c}\text { Use (8) } \\
\text { Com }\end{array}$ & Ind & $\begin{array}{c}\text { Res (k } \\
\text { Sum }\end{array}$ & $\begin{array}{c}\text { (Wh/mt) } \\
\text { Ann }\end{array}$ & $\begin{array}{l}\text { Fuel } \\
\text { Coal }\end{array}$ & 1 Mil & $\begin{array}{l}(8) \\
\text { oth }\end{array}$ & $\begin{array}{l}\text { Water } \\
g / k W l\end{array}$ \\
\hline $\begin{array}{l}\text { Atlanta } \\
\text { KMWH }\end{array}$ & & .075 & 84 & $\begin{array}{r}30 \\
7,386\end{array}$ & $\begin{array}{r}22 \\
8,313.5\end{array}$ & $11,27 \overline{8}$ & & 900 & 80 & - & 20 & NA \\
\hline $\begin{array}{l}\text { Boston } \\
\text { KMWH }\end{array}$ & & .097 & 81 & $\begin{array}{r}4.5 \\
54.382\end{array}$ & $862.002=$ & $\begin{array}{r}12 \\
210.039\end{array}$ & 465 & 490 & - & 100 & - & .15 \\
\hline $\begin{array}{l}\text { Dallas } \\
\text { MMWH }\end{array}$ & & .075 & 97 & $\begin{array}{r}19.2 \\
.38735\end{array}$ & $\begin{array}{r}33.8 \\
8.38109\end{array}$ & $\begin{array}{r}5.6 \\
1.26709\end{array}$ & 1,182 & 1,418 & 45 & 51 & 4 & $\mathrm{NA}$ \\
\hline $\begin{array}{l}\text { Denver } \\
\text { KMWH }\end{array}$ & & .079 & 15 & $\begin{array}{r}3.7 \\
18.178\end{array}$ & $C \& \frac{I}{28}$ & $\begin{array}{l}=14.1 \\
9,140.6\end{array}$ & NA & 537 & 98 & 2 & - & $\mathrm{NA}$ \\
\hline $\begin{array}{l}\text { Fresno } \\
\text { MMWH }\end{array}$ & & .107 & 63 & 21.444 & $\begin{array}{r}26.7 \\
487.123\end{array}$ & $\begin{array}{r}29.4 \\
223.655\end{array}$ & 507 & 517. & - & 100 & - & $\mathrm{NA}$ \\
\hline $\begin{array}{l}\text { Los Angeles } \\
\text { GWH }\end{array}$ & & .094 & $\mathrm{NA}$ & $\begin{array}{r}8.5 \\
581.06\end{array}$ & $\begin{array}{r}42 \\
4,762\end{array}$ & $\begin{array}{r}39.2 \\
1,207\end{array}$ & 600 & 570 & 54 & 23 & 23 & $\mathrm{NA}$ \\
\hline Miami & & & & & IOT AVAIL & ABIE AT & PRESEN & & & & & \\
\hline $\begin{array}{l}\text { Minneapolis } \\
\text { KMWH }\end{array}$ & & .070 & 86 & $\begin{array}{r}6.8 \\
426.65\end{array}$ & $\begin{array}{r}12 \\
453.82\end{array}$ & $\begin{array}{r}3 \\
393.58\end{array}$ & 637 & $589^{\circ}$ & 60 & 1 & 39 & 0.3 \\
\hline $\begin{array}{l}\text { Portland } \\
\text { KMWH }\end{array}$ & & .457 & 28 & 96,382 & $\begin{array}{l}\times 6.5 \\
354.9\end{array}$ & $\begin{array}{r}1.2 \\
44.4\end{array}$ & 400 & 536 & 18 & 5 & 77 & 0.85 \\
\hline $\begin{array}{l}\text { Rock Valley } \\
\text { KMWH }\end{array}$ & & .0785 & 51 & $\begin{array}{r}10 \\
111.19\end{array}$ & $\begin{array}{r}16 \\
200.19\end{array}$ & $\begin{array}{l}\text { NA } \\
\text { NA }\end{array}$ & 703 & 558 & 99 & 1 & - & 0.77 \\
\hline $\begin{array}{l}\text { Tucson } \\
\text { KMWH }\end{array}$ & & .0765 & 60 & $\begin{array}{r}17 \\
351.85\end{array}$ & $\begin{array}{r}35 \\
417.89\end{array}$ & $\begin{array}{r}17 \\
297.71\end{array}$ & 750 & 718 & 99 & 1 & - & 0.6 \\
\hline $\begin{array}{l}\text { Washington } \\
\text { GIGA }\end{array}$ & DC & .0628 & 97 & $\begin{array}{r}14.5 \\
1,754\end{array}$ & $\begin{array}{r}24.8 \\
6,689\end{array}$ & - & NA & 652 & 85 & 15 & - & $\mathrm{NA}$ \\
\hline
\end{tabular}


Table B-2

Natural Gas Utility Data

\begin{tabular}{|c|c|c|c|c|c|c|c|}
\hline City & $\begin{array}{l}\text { Res Rate } \\
\text { \$/therm }\end{array}$ & $\begin{array}{l}8 \\
\text { WNG }\end{array}$ & Res & $\begin{array}{l}\text { NG Heat } \\
\text { Com }\end{array}$ & $\begin{array}{l}\text { Use ( } 8) \\
\text { Ind }\end{array}$ & $\begin{array}{l}\text { Res } \\
\text { Win }\end{array}$ & $\begin{array}{c}\text { (th/mt) } \\
\text { Ann }\end{array}$ \\
\hline $\begin{array}{l}\text { Atlanta } \\
\text { Mth }\end{array}$ & .62 & 78 & $\begin{array}{r}55 \\
476.4\end{array}$ & $\begin{array}{r}36 \\
155.9\end{array}$ & NA & $\mathrm{NA}$ & 67 \\
\hline $\begin{array}{l}\text { Boston } \\
\text { MMMBtu }\end{array}$ & .738 & NA & $\begin{array}{r}89.4 \\
30.464\end{array}$ & $\begin{array}{r}85 \\
10.257\end{array}$ & $\begin{array}{r}53.4 \\
1.136\end{array}$ & 241 & 122 \\
\hline $\begin{array}{l}\text { Dallas } \\
\mathrm{BCF}\end{array}$ & .582 & 92 & $\begin{array}{r}63 \\
50.652\end{array}$ & NA & NA & 104 & 67 \\
\hline $\begin{array}{l}\text { Denver } \\
\text { MMCF }\end{array}$ & .42 & 98 & $\begin{array}{r}64.6 \\
5.3134\end{array}$ & NA & NA & NA & 94 \\
\hline $\begin{array}{l}\text { Fresno } \\
\text { Mth }\end{array}$ & .51 & 80 & $\begin{array}{r}64.3 \\
65.646\end{array}$ & $\begin{array}{r}74 \\
35.303\end{array}$ & $\begin{array}{r}61 \\
32.975\end{array}$ & 71 & 48 \\
\hline $\begin{array}{l}\text { Los Angeles } \\
\text { BMCF }\end{array}$ & .801 & NA & $\begin{array}{r}47.25 \\
106.79\end{array}$ & $\begin{array}{l}45.08 \\
39.61\end{array}$ & $\begin{array}{l}4.15 \\
4.29\end{array}$ & 17 & 24 \\
\hline Miami & & & NOT $A$ & APPLICABL & & & \\
\hline $\begin{array}{l}\text { Minneapolis } \\
\text { MMCF }\end{array}$ & .51 & 94 & $\begin{array}{r}70 \\
19.3\end{array}$ & NA & $\mathrm{NA}$ & 150 & .100 \\
\hline $\begin{array}{l}\text { Portland } \\
\text { Mth }\end{array}$ & .571 & $\mathrm{NA}$ & $\begin{array}{r}95 \\
192.86\end{array}$ & $\begin{array}{r}88 \\
143.29\end{array}$ & $\begin{array}{r}23 \\
13.39\end{array}$ & 111 & 64 \\
\hline $\begin{array}{l}\text { Rock Valley } \\
\text { MMCF }\end{array}$ & .403 & 96 & $\begin{array}{r}63 \\
12.344\end{array}$ & $\begin{array}{r}62 \\
10.541\end{array}$ & $\mathrm{NA}$ & 234 & 121 \\
\hline \multicolumn{2}{|l|}{ Tucson } & \multicolumn{4}{|c|}{ NOT AVAILABLE AT PRESENT } & & \\
\hline $\begin{array}{l}\text { Washington DC } \\
\text { Mth }\end{array}$ & x . .75 & NA & $\begin{array}{r}74 \\
104\end{array}$ & .02 & NA & & 71 \\
\hline
\end{tabular}


Table B-3

Water Utility Data

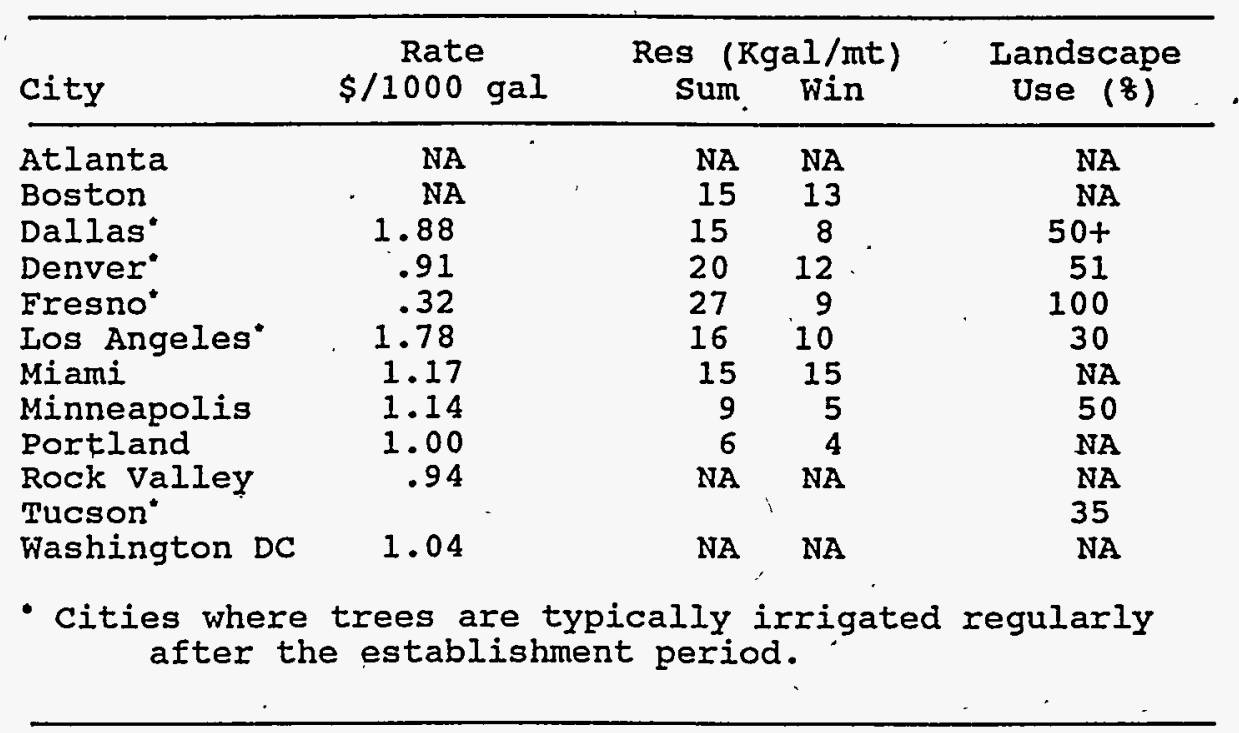


Appendix C

Environmental Data for Demonstration Cities

Table C-1

Energy Conservation, Air Quality, and stormwater Management Data

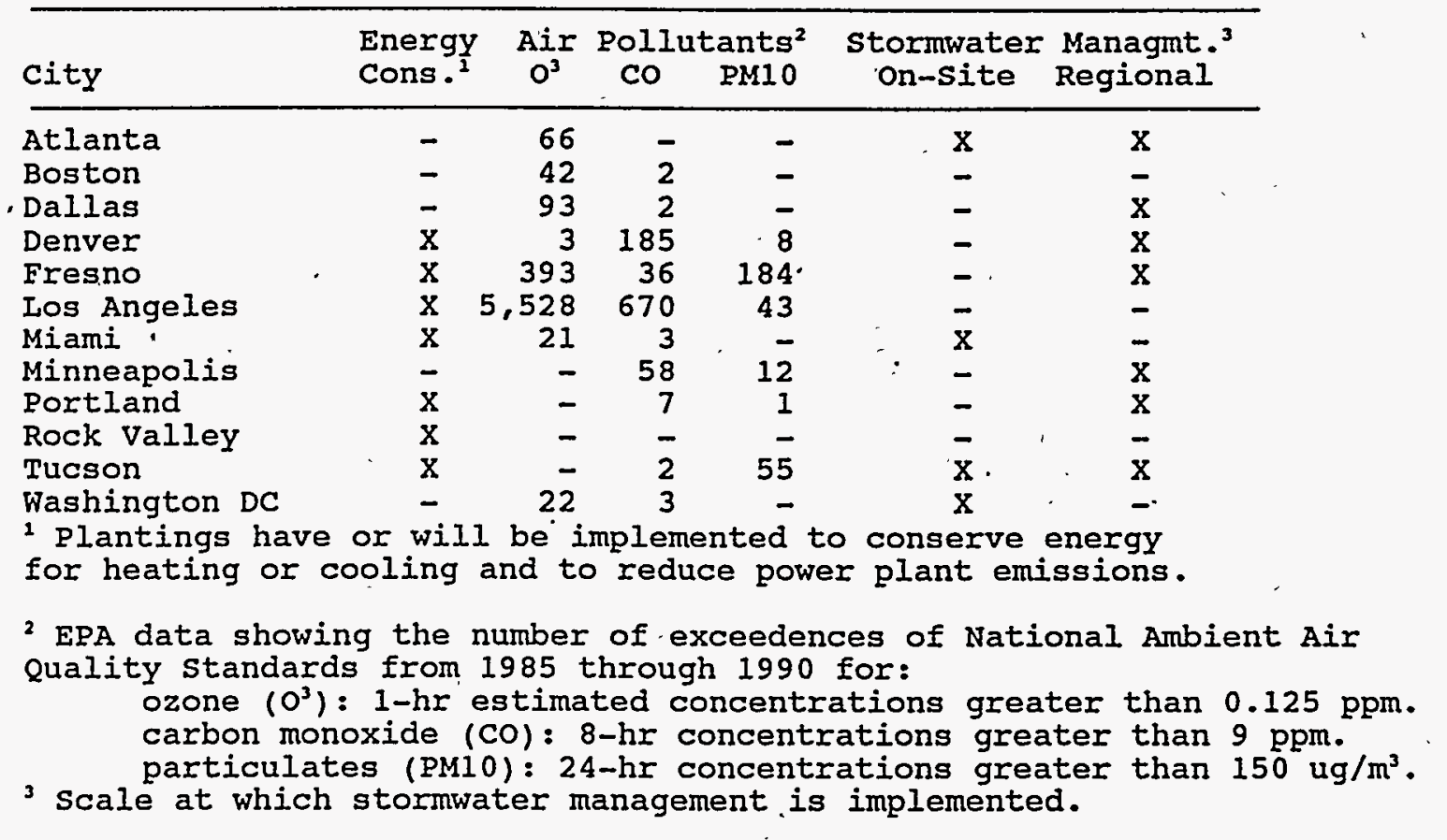


Table C-2

Control Costs of Selected Air Pollutants (\$/Ton)

\begin{tabular}{|c|c|c|c|c|c|}
\hline $\begin{array}{l}\text { Pollution Sources } \\
\text { and Regulations }\end{array}$ & $\begin{array}{c}\text { Carbon } \\
\text { Monoxide }\end{array}$ & $\begin{array}{l}\text { Ozone/ } \\
\text { Vocs }\end{array}$ & $\begin{array}{l}\text { Partic- } \\
\text { ulates }\end{array}$ & $\begin{array}{l}\text { Carbon } \\
\text { Dioxide }\end{array}$ & $\begin{array}{l}\text { Refer- } \\
\text { ence }\end{array}$ \\
\hline $\begin{array}{l}\text { Residual Emissions } \\
\text { California - } 1992\end{array}$ & $\begin{array}{l}1,100- \\
19,300\end{array}$ & $\begin{array}{l}3,500- \\
21,100\end{array}$ & $\begin{array}{l}1,800 \\
11,900\end{array}$ & - & 1 \\
\hline $\begin{array}{l}\text { Residual Emissions } \\
\text { NE U.S. - } 1990\end{array}$ & 909 & 5,539 & 4,180 & 23 & 2 \\
\hline Area Sources & 10,000 & 12,800 & 3,600 & - & 3 \\
\hline Mobile Sources & - & 3,900 & - & - & 3 \\
\hline Point Sources & - & 8,200 & 10,600 & - & 3 \\
\hline $\begin{array}{l}\text { Tier 1 Tailpipe } \\
\text { standards for Cars }\end{array}$ & - & $\begin{array}{c}3,700- \\
6,018\end{array}$ & - & - & 4 \\
\hline $\begin{array}{l}\text { Cold Temp Emission } \\
\text { Cars and Trucks }\end{array}$ & $\begin{array}{l}92- \\
227\end{array}$ & - & - & - & 5 \\
\hline $\begin{array}{l}10 \text { Stationary \& } \\
\text { Mobile Source } \\
\text { Controls }\end{array}$ & - & $\begin{array}{l}400- \\
4,000\end{array}$ & - & - & 6 \\
\hline Road Paving & - & - & 6,451 & - & 7 \\
\hline $\begin{array}{l}\text { Paving \& Chemical } \\
\text { Stabalization }\end{array}$ & - & - & - & $\begin{array}{l}40- \\
340\end{array}$ & 8 \\
\hline $\begin{array}{l}\text { New Source Per- } \\
\text { formance Standards }\end{array}$ & - & 1,134 & 2,722 & - & 9 \\
\hline
\end{tabular}

1. California Energy Commission. "In-state Pollutant Emission Reduction Values and Modeling Assumptions." October, 1991.

2. Estimates made by Tellus Institute. Richard Buell, California Energy Commission, october, 1991.

3. South Coast Air Quality Management District. "Draft Final 1991 Air Quality Management Plan. 1991."

4. U.S. EPA. "Tier 1 Light-Duty Tailpipe Standards and Useful Iife Requirements." January, 1991.

5. U.S. EPA. "Interim Regulations for Cold Temperature Carbon Monoxide Emissions from Iight-Duty Vehicles and Iight-Duty Trucks." January, 1989.

6. R. D. Rapoport. "Analysis of Volatile Organic. Compound Emission Control Methods to Reduce Urban Ozone." June, 1990.

7. M. Duff and K. Brennan. "Rural Fugitive Dust Analysis: Eagle River, Alaska." October, 1988.

8. M. Duff. "Rural Fugitive Dust Analysis: Imperial County, California." September, 1989 .

9. C. I. Elkins and M. Russel1. "Guidelines for Cost-Effectiveness of New Source Performance standards." September, 1985. 
Table $\mathrm{C}-3$

Estimated Costs for Typical Retention/Detention Basins

\begin{tabular}{lccccc}
\hline City (depth) & $\begin{array}{c}\text { Land } \\
\$ / \text { acre }\end{array}$ & $\begin{array}{c}\text { Excavate } \\
\$ / \text { acre }\end{array}$ & $\begin{array}{c}\text { Landscape } \\
\$ / \text { acre }\end{array}$ & $\begin{array}{c}\text { Maintain } \\
\$ / \text { acre/yr }\end{array}$ & $\begin{array}{c}\text { Tot 1st Yr } \\
\$ / \text { acre } \mathrm{ft}\end{array}$ \\
\hline Atlanta $(6 \mathrm{ft})$ & 25,000 & $\begin{array}{c}24,200 \\
2.50 / \mathrm{cy}\end{array}$ & 968 & 250 & 8,403 \\
Denver $(6 \mathrm{ft})$ & 65,000 & $\begin{array}{c}40,650 \\
4.20 / \mathrm{cy}\end{array}$ & 1,000 & 100 & 17,792 \\
Fresno $(18 \mathrm{ft})$ & 50,000 & $\begin{array}{c}87,120 \\
3.00 / \mathrm{cy}\end{array}$ & 9,680 & 580 & 8,189 \\
Portland $(18 \mathrm{ft})$ & 50,000 & $\begin{array}{l}145,200 \\
5.00 / \mathrm{cy} \\
43,560\end{array}$ & 4,840 & 4,840 & 11,382 \\
Tucson $(6 \mathrm{ft})$ & 40,000 & 4,840 & 730 & 14,855 \\
\hline
\end{tabular}

Mr. Roger Purcell, Vice President, Engineering, Planners and Engineers Coliaborative, Atlanta, GA.

Mr. Bob Hoffmaster, Chief of Design and Construction, Urban Drainage and Flood Control, Denver, Co.

Mr. Allan Hoffman, Fresno Municipal Flood Control District, Freson, CA.

Mr. Earling Soli, Supervisor, Bureau of Environmental Services, Portland, OR.

Mr. Tom Nunn, Pima County Department of Transportation and Flood Control, Tucson, AZ . 
Anderrson, B.; W. CarrolI and M. Martin. 1986. "Aggregation of U.S. Population Centers Using Climate Parameters Related to Building Energy Use." Journal of Climate and Applied Meteorology, 25: 596-614.

McPherson, E. G. 1991. "Economic Modeling for Large-Scale Tree Plantings. In : E. Vine, D. Crawley and P. Centolella (Eds.), Energy Efficiency and the Environment: Forging the Link. American Council for an Energy-Efficient Economy, Washington, D.C., pp. 349-369.

Miller, R. W. 1988. Urban Forestry, Planning and Managing Urban Greenspaces. Prentice Hall. Englewood Cliffs, New Jersey.

Nowak, D. J. 199I. "Urban Forest Development and structure: Analysis of Oakland, California." PhD dissertation, University of California, Berkeley, CA.

Rowntree, R.A. 1984. "Forest Canopy Cover and Iand Use in Four Eastern United States Cities." Urban Ecology, 8: 55-67. 
M96006961

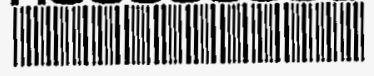

